\title{
A BREAKDOWN OF DEVELOPED COUNTRIES' PUBLIC CLIMATE FINANCE CONTRIBUTIONS TOWARDS THE \$100 BILLION GOAL
}

\section{JULIE BOS AND JOE THWAITES}

\section{INTRODUCTION}

Providing finance to help developing countries undertake climate action is both a moral responsibility and a legal obligation for developed countries. This is rooted in the fact that they are responsible for the majority of cumulative emissions since industrialization began (Ritchie 2019) and generally have greater capacity to provide support. Under the United Nations Framework Convention on Climate Change (UNFCCC), developed countries are obligated to provide financial resources to meet some of the costs incurred by developing countries in undertaking certain obligations under the convention as well as to assist particularly vulnerable developing countries in meeting the costs of climate adaptation (UN 1992, Articles 4.3 and 4.4). As part of the 2009 Copenhagen Accord, developed countries further committed to jointly mobilizing US $\$ 100$ billion per year in climate finance for developing countries by 2020 (UNFCCC 2009, paragraph 8).

The $\$ 100$ billion commitment, recognized in 2010 as part of the Cancun Agreements (UNFCCC 2010, paragraphs 98-99; see Box 1), has been key to building trust and solidarity between developed and developing countries. It also underpins the "grand bargain" behind the Paris Agreement: that developing countries would commit to more ambitious climate action but would require enhanced support from developed countries to do so. The Paris Agreement includes a provision that developed country Parties would continue their existing obligations

\section{CONTENTS}

1. Introduction .1

2. Detailed Methodology .................................. 9

3. Analysis ..........................................................39

4. Conclusions..................................................66

Appendix A: A Comparison of UNFCCC and OECD

Country Categories.........................................67

Abbreviations .............................................. 75

Endnotes ..................................................... 75

References ............................................ 76

Acknowledgments......................................80

Technical notes document the research or analytical methodology underpinning a publication, interactive application, or tool.

Suggested Citation: Bos, J. and J. Thwaites. 2021. "A Breakdown of Developed Countries' Climate Finance Contributions Towards the $\$ 100$ Billion Goal.” Technical Note. Washington, DC: World Resources Institute. Available online at: https://doi.org/10.46830/writn.20.00145. 
under the UNFCCC to provide financial resources to assist developing country Parties, and it further states that developed country Parties should continue to take the lead in mobilizing climate finance in a progression beyond previous efforts (UNFCCC 2015, Articles 9.1 and 9.3). The accompanying decision by the 21st Conference of the Parties (COP) to the UNFCCC that adopted the Paris Agreement also included a commitment by developed country Parties to continue their existing collective mobilization goal (i.e., the $\$ 100$ billion) through 2025 (UNFCCC 2015, paragraph 53).

BOX 1 | Formalizing the US\$100 Billion Commitment

At the 16th Conference of the Parties to the UNFCCC in 2010, Parties formally recognized the $\$ 100$ billion commitment in Decision 1/CP.16:

- "98. Recognizes that developed country Parties commit, in the context of meaningful mitigation actions and transparency on implementation, to a goal of mobilizing jointly USD 100 billion per year by 2020 to address the needs of developing countries;

- 99. Agrees that, in accordance with paragraph $1(\mathrm{e})$ of the Bali Action Plan, funds provided to developing country Parties may come from a wide variety of sources, public and private, bilateral and multilateral, including alternative sources."

Source: UNFCCC 2010, paragraphs 98-99.
Delivery on this climate finance goal will be key to unlocking more ambitious climate commitments from developing countries and ensuring progress in international climate negotiations. Developed countries' ability to deliver $\$ 100$ billion in climate finance annually will also set the tone for deliberations on a future collective climate finance goal, from a floor of $\$ 100$ billion, which governments decided in Paris in 2015 would be agreed upon before 2025 (UNFCCC 2015, paragraph $53)$. The $\$ 100$ billion is a collective commitment by "developed countries," and meeting it will require them all to do their part. However, this is complicated by the developed countries not being clearly defined within the UNFCCC or its Paris Agreement (see Box 2).

Over the past decade, there have been several assessments of aggregate progress towards the goal (see Section 1.1), but until now, no data set has attempted to break down each country's full public financial contribution. This technical note aims to fill this gap, increasing transparency and accountability around progress towards the $\$ 100$ billion commitment by breaking down how much each developed country has contributed in public climate finance for developing countries between 2013 and $2018,{ }^{1}$ the most recent year for which comprehensive data are available. We did not look at private mobilized finance because data on this are much less complete, with methodological challenges in tracking and attributing private mobilized finance to individual countries.

The six-year period 2013-18 spans three years on either side of the Paris Agreement, which was concluded in December 2015, allowing pre- and post-Paris trends to be assessed. We use the individual breakdowns to assess how countries' efforts compare using a variety of metrics. In the process of attempting to quantify and break down climate finance contributions, we identify several methodological barriers to providing fully comprehensive individual country breakdowns of public climate finance, and this technical note outlines these, our efforts to address them, and the outstanding barriers. 
B0X 2 | Categorizing Developed and Developing Countries under the United Nations Framework Convention on Climate Change

The US\$100 billion commitment refers to finance from "developed country Parties" for "developing country Parties." These are not explicitly defined in Decision 1/CP.16. ${ }^{a}$ Any accounting approach requires the delineation of the categories of developed and developing countries. The United Nations Framework Convention on Climate Change (UNFCCC) $)^{b}$ established two annexes:

- Annex I contains "developed country Parties and other Parties," including those "undergoing the process of transition to a market economy."

- Annex II contains "developed country Parties and other developed Parties included in Annex II" with "other developed Parties" referring to the noncountry European Economic Community (later superseded by the European Union). This group comprises countries that were members of the Organisation for Economic Co-operation and Development (OECD) in 1992. The obligation to provide climate finance set out in Articles 4.3 and 4.4 of the UNFCCC is assigned to Annex II Parties. All Annex II Parties are in Annex I, but not all Annex I Parties are in Annex II.

- All other Parties are deemed "non-Annex I Parties."

Figure B2.1 shows a map of UNFCCC Parties by annex.

\section{FIGURE B2.1: MAP OF UNFCCC PARTIES}

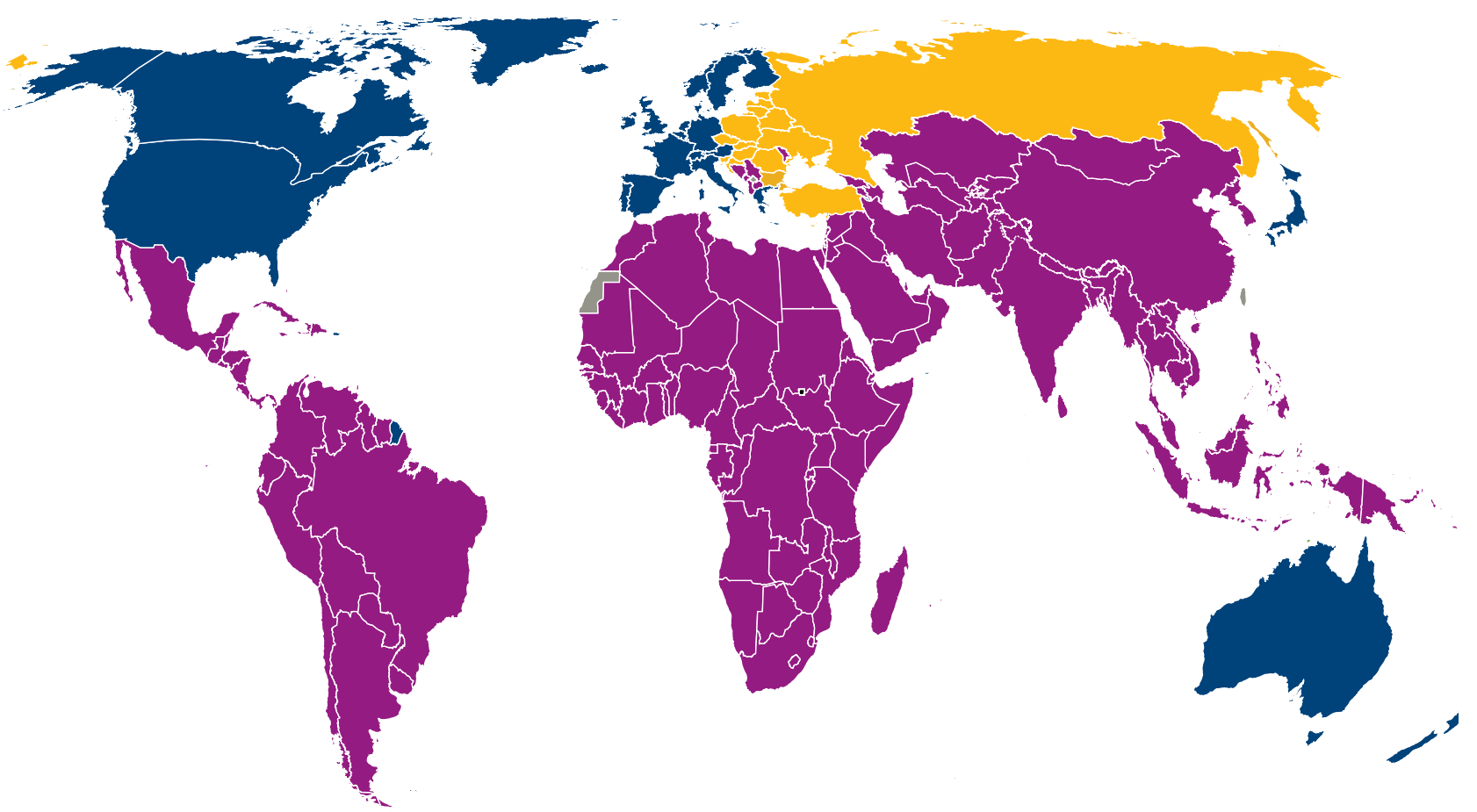

UNFCCC non-Annex I Parties

UNFCCC Annex I Parties not in Annex II

UNFCCC Annex I Parties also in Annex II

Notes: UNFCCC = United Nations Framework Convention on Climate Change. The Holy See is an observer state.

Source: WRI, based on annexes in UN 1992. 
B0X 2 | Categorizing Developed and Developing Countries under the United Nations Framework Convention on Climate Change (con't.)

The $\$ 100$ billion commitment in Decision 1/CP.16 refers to the commitment being by "developed country Parties," but not "other developed Parties in Annex II," presumably excluding the European Union itself from the obligation (but not EU member states that are developed country Parties).

We therefore define developed country Parties as the 23 countries in Annex II of the UNFCCC:

$\begin{array}{lll}\text { Australia } & \text { Greece } & \text { Norway } \\ \text { Austria } & \text { Iceland } & \text { Portugal } \\ \text { Belgium } & \text { Ireland } & \text { Spain } \\ \text { Canada } & \text { Italy } & \text { Sweden } \\ \text { Denmark } & \text { Japan } & \text { Switzerland } \\ \text { Finland } & \text { Luxembourg } & \text { United Kingdom of Great Britain } \\ \text { France } & \text { Netherlands } & \text { and Northern Ireland } \\ \text { Germany } & \text { New Zealand } & \text { United States of America }\end{array}$

This is the same definition as used by the Overseas Development Institute ${ }^{c}$ as well as peer-reviewed academic literature. ${ }^{d}$ This differs from the OECD's approach, which, in addition to counting climate finance from Annex II Parties, also includes climate finance from other member states of the European Union not in Annex II (Bulgaria, Croatia, Cyprus, Czechia, Estonia, Hungary, Latvia, Lithuania, Malta, Poland, Romania, Slovakia, and Slovenia)e as well as Liechtenstein and Monaco, which are Annex I Parties not included in Annex II. ${ }^{\dagger}$

We define developing country Parties as all the non-Annex I Parties to the UNFCCC. However, many countries include climate finance provided to Annex I Parties not included in Annex II, namely Eastern European countries and Turkey, in their UNFCCC reporting. Similarly, the OECD's climate finance reports include climate finance going to non-Annex I Parties but also countries in Annex I that are eligible to receive official development assistance (ODA): Belarus, Kosovo, Turkey, and Ukraine. ${ }^{9}$ Turkey was originally included in Annex II but was deleted from it by an amendment that entered into force on June 28, 2002, pursuant to Decision 26/CP.7.h Turkey has since requested to be eligible to receive climate finance under the UNFCCC and the Paris Agreement. We did not make adjustments to exclude climate finance received by Annex I countries; however, the absence of a clear definition of developing countries in the $\$ 100$ billion commitment means that it is not clear whether all such flows should be counted towards the goal.

OECD Development Assistance Committee climate finance reporting, which is narrower in scope than the OECD climate finance reports, only includes finance to ODA-eligible countries, which excludes the following non-Annex I Parties: Andorra, Bahamas, Bahrain, Barbados, Brunei Darussalam, Chile (since 2018, when it graduated from ODA eligibility), Israel, Kuwait, Oman, Qatar, Saint Kitts and Nevis (since 2014, when it graduated from ODA eligibility), San Marino, Seychelles (since 2018, when it graduated from ODA eligibility), Singapore, State of Palestine, Trinidad and Tobago, United Arab Emirates, and Uruguay (since 2018, when it graduated from ODA eligibility): 
B0X 2 | Categorizing Developed and Developing Countries under the United Nations Framework Convention on Climate Change (con't.)

Figure B2.2 shows how the UNFCCC and OECD country categories do not fully align. Table A1 in the appendix lists all countries that are Parties to the UNFCCC by their UNFCCC annex as well as by their eligibility for ODA between 2013 and 2018.

FIGURE B2.2: HOW THE UNFCCC AND OECD COUNTRY CATEGORIES DO NOT FULLY ALIGN

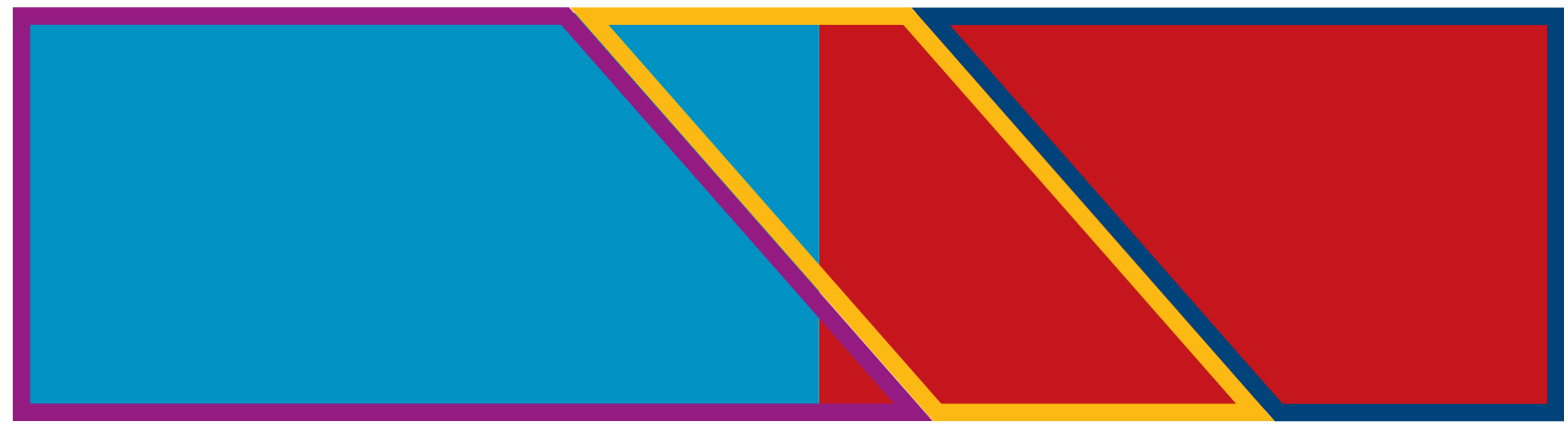

ODA-eligible countries

$\square$ UNFCCC non-Annex I Parties

Non-ODA-eligible countries

$\square$ UNFCCC Annex I Parties not in Annex II

$\square$ UNFCCC Annex I Parties also in Annex II

Notes: $\mathrm{ODA}$ = official development assistance; UNFCCC = United Nations Framework Convention on Climate Change. Figure for illustrative purposes only, areas not to scale. The categorization misalignment is shown by the green and red triangles created by the UNFCCC country definitions crossing the Organisation for Economic Co-operation and Development ODA eligibility boundary.

Source: WRI authors.

\section{Notes:}

a. UNFCCC 2010.

b. UN 1992.

c. Colenbrander et al. 2021.

d. Weikmans and Roberts 2019.

e. In 1992, when the UNFCCC was agreed upon, these countries were not members of the European Economic Community/European Union.

f. OECD 2015, 2019, 2020 .

g. OECD 2020.

h. UNFCCC 2001

i. OECD 2012, 2014, 2018a. 


\subsection{Existing Public Climate Finance Data Sources and Analysis}

Ex post data on public climate finance provided individually by developed countries to developing countries comes through three main sources:

Since 2014, all Annex I Parties ${ }^{2}$ to the UNFCCC are required to submit Biennial Reports (BRs), which include data in a common tabular format (CTF) on the climate finance they provide to developing countries (UNFCCC 2016, 2018b, 2020). Because these reports are due only on even-numbered years and cover a reporting period two and three years prior, it means that there is a lag in data availability. Thus, official data on 2019 and 2020 climate finance provision is not due to be reported to the UNFCCC until 2022.

Multilateral development banks (MDBs) issue annual joint climate finance reports, which have been published every year since 2011 and include aggregate data on climate finance provided during the prior fiscal year (ADB 2016c; EBRD 2017, 2018, 2019; EIB 2014; World Bank 2015). This data covers their total climate finance provision and does not adjust to cover only the portion attributable to developed country inputs, which would be necessary for assessing progress towards the $\$ 100$ billion goal.

The Creditor Reporting System (CRS) of the Organisation for Economic Co-operation and Development (OECD) collates activity-level reporting on climate-related development assistance from countries that are members of the Development Assistance Committee (DAC) as well as some multilateral institutions, including MDBs (OECD 2021a). Many countries base their biennial reporting to the UNFCCC on what they report through the OECD CRS, so there are some similarities in these data sets. Multilateral data in the CRS are available for both inflows from contributor countries and outflows to recipients.

Although the $\$ 100$ billion commitment stated that it was a mobilization goal and that funding may come from both public and private sources, it left significant ambiguities, with no clear definition of what and how to account towards the goal (Bodnar et al. 2015). This is partly because the $\$ 100$ billion was a political commitment, made in the polarized context of COP15 in Copenhagen. A variety of institutions have attempted to assess progress on the provision and/or mobilization of climate finance. These different assessments of progress have different scopes:

The UNFCCC's Standing Committee on Finance (SCF) has produced a Biennial Assessment (BA) and Overview of Climate Finance Flows every two years since 2014, compiling data from BRs and MDB reporting (SCF 2014, 2016, 2018). It presents climate finance data from various channels and includes tables summarizing data from developed countries' BRs as well as their climate-marked ODA reported to the OECD. BAs are usually released shortly before COPs on even-numbered years, but due to COP26's postponement, the fourth BA, originally scheduled for 2020, will be published in 2021.

The OECD has produced semiregular assessments (in 2015, 2019, and 2020) of progress towards the $\$ 100$ billion goal. OECD figures include four mutually exclusive components: bilateral public climate finance (based on BRs to the UNFCCC), multilateral climate finance (based on data reported to the OECD DAC $\mathrm{CRS)}$ attributed to developed countries, bilateral export credits (based on data reported to the OECD Export Credit Group), and private finance mobilized by bilateral and multilateral public climate finance (reported to the OECD DAC CRS) attributed to developed countries (OECD 2015, 2019, 2020).

\section{Oxfam has produced Climate Finance Shadow} Reports in 2016, 2018, and 2020 (Carty and Le Comte 2018; Carty et al. 2016, 2020). These reports adjust the BR data to count only the grant equivalent of loans reported and adjust the climate-specific share of development projects reported, which results in a lower estimate of climate-specific net financial assistance from developed to developing countries compared to donor self-reporting.

\section{The United Nations Secretary-General} (UNSG) convened an independent expert group on climate finance that released a report in 2020 (Bhattacharya et al. 2020) that assessed progress towards the $\$ 100$ billion target. Drawing on the above three sources, it reviewed and collated different assessments and critiques of climate finance accounting and reporting, and it made projections of where climate finance flows might have reached in 2020. 
The Center for Global Development (CGD) produced a paper that compared country reporting of climate-specific finance as included in the OECD's reports against total development finance reported to the OECD to assess the extent to which climate finance provided since 2009 is "new and additional" (Mitchell et al. 2021).

\section{The Overseas Development Institute (ODI)}

produced a paper looking at ways to apportion responsibility among developed countries for the $\$ 100$ billion climate finance goal (Colenbrander et al. 2021). It drew on OECD and Oxfam data on public climate finance provision in 2017-18, then compared this against a composite index that attempts to apportion climate finance responsibility based on developed countries' gross national income (GNI) in 2019, population in 2019, and cumulative carbon dioxide emissions between 1990 and 2018. The analysis focuses on Group of Seven (G7) countries plus Australia, with other developed countries grouped together.

These analyses are useful contributions to the literature on progress towards the $\$ 100$ billion target. However, they have some limitations:

The BA summarizes information provided through the BRs, OECD climate-marked ODA data, and MDB climate finance, but it makes only minor adjustments to the data (e.g., ensuring all data are converted to U.S. dollars). The assessment does not explicitly opine on progress towards the $\$ 100$ billion goal, and due to different methodologies, the numbers from different sources cannot simply be summed together without risking double counting (for example, contributions to MDBs are included in some countries' BRs and also in MDB joint reporting). The BA does not exclude coal financing that has been included by Australia and Japan in their reporting to the UNFCCC.

The OECD and Oxfam reports do adjust data to help reduce double counting, exclude coal financing included by Japan in their reporting to the UNFCCC, and take a position on progress towards the $\$ 100$ billion goal. However, the OECD does not provide a breakdown of how much climate finance each country provides. Oxfam provides a partial breakdown of bilateral flows for selected countries, but not a full breakdown including multilateral flows and all developed countries.
The OECD reports do adjust MDB climate finance outflows data to account only for developed countries' collective share, but they do not provide a countryby-country breakdown that can be added to each country's total climate finance.

The independent report commissioned by the UNSG reviews the BA, OECD, and Oxfam reports. The report suggests that there may be some overreporting by developed countries of around $\$ 3-\$ 4$ billion per year. It also makes an informed projection of where climate finance towards the $\$ 100$ billion goal might be in aggregate by 2020 , but it does not provide country breakdowns (Bhattacharya et al. 2020).

The CGD's analysis is based on OECD data, so it shares similar limitations. In addition, the CGD focuses only on climate finance inflows, so it does not fully capture developed countries' attributed shares of MDB climate finance outflows.

The ODI analysis is based on OECD and Oxfam data, so it shares similar limitations. Although ODI does break down the contributions to G7 countries (Canada, France, Germany, Italy, Japan, the United Kingdom, and the United States) and Australia, these do not include shares of finance provided through MDBs.

- No existing analysis attributes the shares of climate finance from EU institutions to individual member states. Climate finance from EU institutions is often listed separately. However, since the European Union cannot raise its own resources through taxation, it is akin to other international institutions that rely on member states for core budgetary contributions. A full assessment of how much each individual developed country can claim to have provided as climate finance would require shares of climate finance from $\mathrm{EU}$ institutions to be attributed back to contributing developed country member states.

\subsection{The World Resources Institute's Approach}

The World Resources Institute (WRI) is filling a gap in the data by providing a detailed breakdown of how much public climate finance each country provides that might be counted towards the $\$ 100$ billion commitment. Although the $\$ 100$ billion is a collective goal, just as with collective mitigation targets such as $1.5^{\circ} \mathrm{C}$ or net zero, it depends on the actions of individual countries being 
sufficient to add up to the total; therefore, transparent data on individual country contributions are vital. It is unlikely the $\$ 100$ billion commitment was met on time in 2020 (Bhattacharya et al. 2020). By improving transparency around public climate finance provision, our aim is to improve the accountability of individual developed countries and assess which countries need to do more to ensure the commitment is delivered.

At WRI, we synthesized existing public climate finance reporting from Annex II Parties under the UNFCCC in their BRs, as well as MDBs in their reporting to the OECD CRS, and adjusted this data to help eliminate double counting. We built on methodologies used by the SCF and the OECD, and some of our aggregate numbers are likely to be similar to those of the BA's appendix table compiling CTF data and the OECD's climate finance reports. We also went a step further and provided a country-by-country breakdown that attributes climate finance through MDBs and the European Union to each individual Annex II contributor country. In this way, we provided an easily accessible snapshot of how much each Annex II country can claim to have provided as public climate finance to developing countries (see Box 2 for country definitions). Since we did not include private mobilized finance, our analysis did not attempt to assess overall progress towards the $\$ 100$ billion goal. Table 1 shows how our analysis compares with previous analyses.

\section{Table 1 | Comparison of Existing Analyses of Public Climate Finance Relevant to the \$100 Billion Goal}

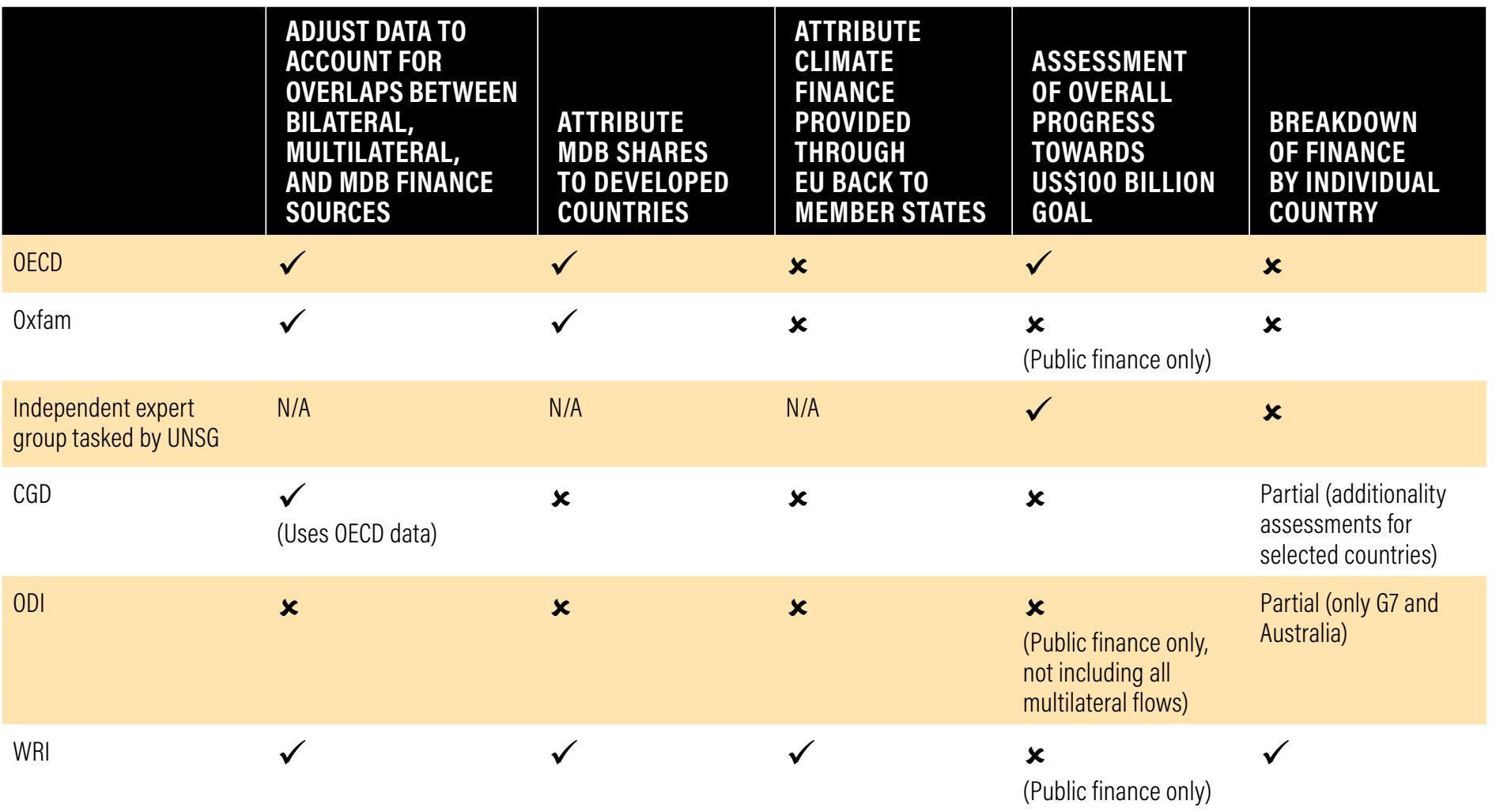

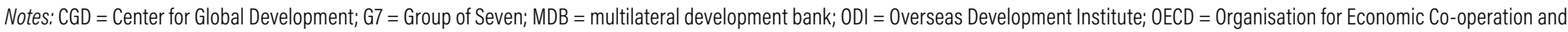
Development; UNSG = United Nations Secretary-General.

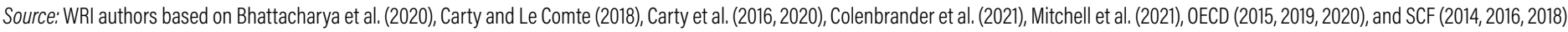


Our analysis provided a breakdown of how much public climate finance each country has provided, through which channels (bilateral, climate-specific inflows to multilateral institutions and climate-specific outflows from MDBs attributed back to developed countries), and to which thematic areas (mitigation, adaptation, crosscutting, and other) over the years 2013-18. We also compared country climate finance as a percent of GNI, per capita, and compared against a variety of climate finance effortsharing approaches. The latter approaches were developed by different research institutions and nongovernmental organizations that use objective data to suggest potential equitable approaches to dividing effort towards meeting climate finance goals. When developed countries submit their fifth BRs, due in 2022, our methodology can also be applied to these new data to provide updated climate finance breakdowns for 2019 and 2020.

\subsection{Limitations}

In the process of accounting for a country's individual contribution to the $\$ 100$ billion goal, we encountered several methodological barriers; thus, there are important limitations and caveats in our analysis (see Section 2.1, Methodological Challenges, for more detail). They span technical issues in how countries and institutions report climate finance and qualitative differences in what countries choose to report as climate finance. At the root of both is the fact that the original $\$ 100$ billion commitment was not sufficiently clear on what counts towards the goal and how to account for it (Bodnar et al. 2015), and governments have been unable to reach agreement on clarifying these questions. The lack of consistency in reporting can have a significant impact on the amount of finance attributable to countries; for some of the higher-contributing countries, this amounts to billions of dollars a year. When interpreting the data, it is important to bear in mind that approaches vary considerably between countries; whereas higher-reporting contributors may have a more

\section{liberal interpretation of what finance flows to include, lower-reporting contributors may have taken a more conservative approach. Greater} consistency in reporting approaches among contributors is important for building confidence in climate finance data and enabling a more accurate assessment of relative efforts. The enhanced transparency framework under the Paris Agreement provides an opportunity to further advance this effort.

\subsection{Structure}

Section 2 provides a detailed methodology of adjustments made to the source data, and Section 3 contains analysis of the collated and adjusted data according to the thematic split between mitigation and adaptation and against various effort metrics. Section 4 contains brief conclusions.

\section{DETAILED METHODOLOGY}

In this section, we explain how we calculated and allocated public climate finance through the following sources: bilateral, climate-specific inflows to multilateral institutions and outflows from MDBs. Figure 1 outlines the key methodological steps of the climate finance breakdown, which are outlined in further detail in the subsections.

We did not normalize dollar amounts to a given year. The $\$ 100$ billion target was due in 2020 and must continue through 2025, but the COP decision did not specify that amounts be pegged to inflation of a particular year, and no other assessments of climate finance towards the $\$ 100$ billion have attempted to normalize amounts between years. 


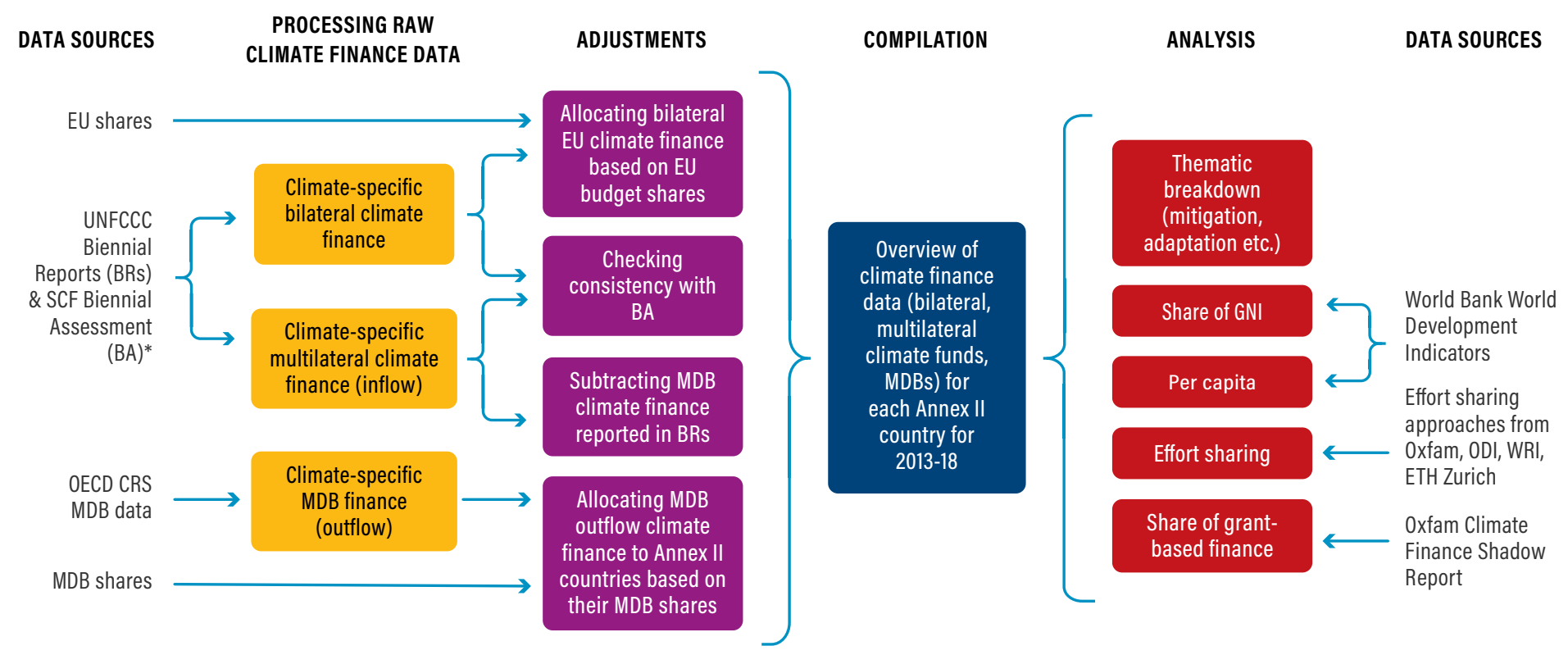

* When the numbers differed we used the numbers from the BA because these numbers are reviewed by the SCF experts

Notes: $\mathrm{CRS}=$ Creditor Reporting System; EU = European Union; GNI = gross national income; $\mathrm{MDB}=$ multilateral development bank; $\mathrm{OECD}=$ Organisation for Economic Co-operation and Development; SCF = Standing Committee on Finance; UNFCCC = United Nations Framework Convention on Climate Change.

Source: WRI authors.

\subsection{Methodological Challenges}

This technical note identified numerous issues with climate finance as currently reported, spanning both technical issues in how countries and institutions report climate finance qualitative differences in what countries choose to report as climate finance (Carty and Le Comte 2018; Carty et al. 2016, 2020; Roberts et al. 2021; SCF 2014, 2016, 2018; Weikmans and Roberts 2019). Below, we present the key issues and our approach to addressing them.

\section{Reporting inconsistencies and errors}

Some countries made data calculation or data entry errors, such as adding values incorrectly, not converting from national currencies to U.S. dollars, or mixing national currency and U.S. dollar figures. We made simple adjustments for clear instances of data entry errors or omissions of currency conversions.
In case of discrepancies between the BRs and the BAs, we used the data presented in the BAs; as part of their compilation, BAs attempt to correct for data entry errors and inconsistencies in the CTFs. We sent calculations to representatives from all 23 Annex II countries included in our analysis, and if they identified issues, we corrected them (these are explained in more detail below).

Countries report finance as "committed" or "disbursed." The OECD defines commitment as "a firm obligation, expressed in writing and backed by the necessary funds, undertaken by an official donor to provide specified assistance to a recipient country or a multilateral organization" and disbursement as "the release of funds to or the purchase of goods or services for a recipient; by extension, the amount thus spent. Disbursements record the actual international transfer of financial resources, or of goods or services valued at the cost to the donor" (OECD n.d.). 
Some countries report both commitments and disbursements, and this can lead to double counting if countries report commitments in one year and disbursements to the same entity or project in the same or subsequent years. We corrected clear instances of this where countries reported committed and disbursed finance to multilateral institutions in the same year, as detailed below. We did not correct bilateral finance reporting; thus, for countries that report both commitments and disbursements, there is a risk of double counting, especially between years (i.e., if counted in one year when reported as committed, then again in a subsequent year when reported as disbursed). This is a key reporting issue with the UNFCCC BRs and merits further investigation.

\section{Failure to report}

The United States has not submitted its third or fourth BRs-due in January 2018 and January 2020, respectively-to the UNFCCC. This means there is incomplete official climate finance data for the United States.

Rather than attempt to estimate using other data sources, which would be inconsistent with other countries, we noted these data gaps; and where postParis averages were calculated for other countries, we presented only the 2016 amounts for the United States. If the United States submits its overdue BRs, we can update the U.S. calculations with the latest data.

\section{Definitional issues}

The $\$ 100$ billion commitment, in particular, and the UNFCCC, in general, has neither defined nor identified developing countries. Some countries include climate finance contributions to Annex I Parties in their reporting and may exclude non-Annex I countries that are not ODA eligible from their reporting (see Box 2 in Section 1 for further discussion).

The UNFCCC does not give clear definitions of multilateral and bilateral funding, even though its reporting guidelines use these terms. Bilateral flows generally refer to funding from one government directly to another government or local institution in a developing country, such as nongovernmental organizations or researchers. Multilateral flows generally refer to funding that is delivered via an international institution, where resources from multiple contributors are pooled and subject to a shared governance structure before being allocated. Multilateral flows include funding to climate-specific funds such as the Green Climate Fund (GCF) and the Adaptation Fund, UN agencies, and MDBs.

\section{The UNFCCC BR guidelines require Annex II} Parties to submit this information through CTFs: one table for climate finance "contributions through bilateral, regional and other channels" and another for "contributions through multilateral channels" (UNFCCC 2012, Tables 7[b] and 7[a]). Although regional channels may include institutions that could be considered multilateral channels, we kept all data reported under Table $7(\mathrm{~b})$ together to align with the UNFCCC approach.

The BR CTF template lists a set of multilateral institutions in the multilateral finance table $(7[\mathrm{a}]) ;^{3}$ however, some countries still list contributions to such multilateral entities in their bilateral reporting table (7[b]). We did not correct this because it does not affect country totals; however, this may be a reporting error and could skew the breakdown between bilateral and multilateral finance amounts.

\section{Share of project cost counted}

For projects that target multiple development objectives beyond solely climate, countries take different approaches for what share of the cost to count as climate finance. Whereas some countries calculate the climate share on a project-by-project basis, others use fixed coefficients that range from 25 percent to 100 percent (OECD 2015; Weikmans and Roberts 2019). These choices can make a significant difference in the amounts that countries report as climate finance (Carty and Le Comte 2018; Carty et al. 2016, 2020).

The lack of consistency in how countries reported their climate finance to the UNFCCC-with some countries reporting at the project level and others aggregating contributions-made it impossible to verify assumptions, and we were not able to make corrections in a fair way using BR data. This represents a key limitation of our analysis. 


\section{Accounting for different financial instruments}

Countries take different approaches in whether and how to report the value of nongrant instruments as climate finance. Some countries report mostly or entirely grant-based finance, whereas others report significant shares of loans. Other things being equal, governments that provide more grant finance are, in some senses, exerting more budgetary "effort" than governments that provide loans because the creditor government will eventually be repaid.

Reporting currently only requires amounts to be reported at face value, regardless of instrument. "Grant-equivalent" accounting would result in countries with a high proportion of loans and other nongrant instruments reporting significantly lower sums (Carty and Le Comte 2018; Carty et al. 2016, 2020).

Although methodologies exist for reporting the grant equivalence of loans, standardized methodologies for reporting the grant equivalence of equity, guarantees, and insurance do not yet exist.

We did not convert for grant equivalence, but we did include Oxfam data on the share of grant-based finance in bilateral and multilateral inflows (Carty et al. 2020) alongside our figures, and we shaded tables and figures accordingly to illustrate qualitative differences in financial instruments.

\section{Fossil fuel financing}

Some countries include support for fossil fuel projects in their climate finance reporting, but others have opposed such inclusion. Australia and Japan have argued in favor of the inclusion of high efficiency coal plant finance in their climate finance reporting (OECD 2015; TWG 2015). The lack of granular reporting transparency means it is difficult to verify whether countries report fossil fuel finance as climate finance.

Oxfam estimated that Japan reported $\$ 1$ billion in coal finance in $2017-18$, with over $\$ 700$ million reported by Japan for one coal-fired power plant in Bangladesh (Carty et al. 2020). The OECD's reports have excluded coal finance from their aggregate figures (OECD 2015, 2019, 2020).

Due to limited project-level transparency in BRs, it is not possible to identify and exclude finance going to coal or other fossil fuel projects from our calculations.
We added notes flagging that Japan have reported significant amounts of coal finance throughout our analysis because the exclusion of such financing would reduce their amounts.

\section{Export credits}

Whereas some countries include export credit finance in their climate finance reporting, others do not.

We did not adjust to remove export credits where countries choose to report this; however, there is not agreement about whether such credits should count towards the $\$ 100$ billion commitment.

\section{Financing for institutions in developed countries}

Some countries include support provided to researchers and nongovernmental organizations based in developed countries (including WRI) in what they report as climate finance.

We did not adjust where countries choose to report this; however, it is not clear that this should count towards the $\$ 100$ billion commitment.

\section{Additionality}

There are a wide variety of interpretations of whether and how climate finance towards the $\$ 100$ billion should be "new and additional" (Bodnar et al. 2015). Countries are asked to explain in their BRs how the finance they provide is new and additional.

- The CGD's paper estimates that as much as half of reported climate finance may not be additional to existing development assistance flows (Mitchell et al. 2021).

We did not adjust for this; however, the question of additionality is subject to significant debate.

\section{Accounting for contributions to multilateral institutions}

In their BRs, countries are required to report their contributions to multilateral institutions, or inflows. However, outflows from multilateral institutions to recipient countries may be larger, especially if the institutions provide outflows as loans or are able to raise additional resources from capital markets through bond issuances (particularly MDBs). Looking at inflows and outflows will therefore present different amounts (see Figure 2). To address this, we presented 
two perspectives: climate-specific inflows, which include bilateral climate finance and multilateral climate finance, and total attributed climate finance, which adds the attributed MDB outflows (see Section 3.1, Total Public Climate Finance).

It often takes time for a multilateral institution to program the financial resources it receives, so the year in which a contributor country reports a climate finance inflow to a multilateral institution can be different from the year in which this funding outflows to developing countries. This is not an issue for bilateral finance, which goes directly from the developed to the developing country (see line A in Figure 2). For multilateral contributions, however, it means the amounts will vary depending on whether you measure based on the year of inflow from a contributor country to a multilateral institution or the year of outflow from the multilateral institution to a developing country.

Because MDBs raise significant amounts of funding from capital markets, such that their outflows of climate finance to developing countries are much larger than the inflows they receive from contributor countries, we measured MDB climate finance at the point of outflow (see line $\mathrm{C}$ in Figure 2 and MDB climate finance accounting below).

For other multilateral institutions, we counted at the point of inflow, as reported in the BRs (see line $B$ in Figure 2). Because most non-MDB multilateral institutions do not raise additional resources through capital markets, the discrepancy between inflows and outflows is not as large. However, some multilateral funds do use grant inflows to provide larger nongrant outflows, and our analysis did not capture this. There is also likely to be a temporal mismatch between the year an inflow is reported to a multilateral institution and the year finance outflows from the multilateral to a developing country. Looking at amounts for multiyear periods, as we did, can help address the latter issue to some extent.

Some countries do not attribute climate-specific contributions to some multilateral institutions (such as the Global Environment Facility, which targets multiple environmental objectives) and so report this as being core/general funding; other countries report part or all of such contributions as being climate specific. This means countries can claim different portions as climate finance even when contributing to the same multilateral institutions. In the absence of climate-specific reporting, we were unable to correct this.

\section{MDB climate finance accounting}

Although MDBs report on climate finance outflows in their joint climate finance reports, this data has quality and consistency issues. For example, MDBs do not disclose project-level data underpinning their joint reports, use fiscal years rather than calendar years, and measure at different points in the finance cycle (e.g., board approval, commitment, disbursement), which means actual dates of finance outflows can vary by years.

We used the OECD CRS as our data source for MDB outflows because it provides more consistent, project-level data than MDBs, verified according to OECD reporting rules. The OECD CRS still has some limitations. It only includes ODA-eligible countries (which does not include all UNFCCC non-Annex I Parties eligible to receive climate finance) and some Annex I Parties (see Box 2 and Table A1). It also does not include data from the World Bank's International Finance Corporation (IFC) for 2018. This is due to IFC refusing to disclose its 2018 project-level public climate finance data to the OECD for alleged businessconfidentiality reasons. Better transparency from IFC-especially because it is using public resourceswould address this issue.

We attributed the shares of MDB climate finance outflows back to individual contributor countries based on their shareholding in each MDB. We detail the methodology for attributing shares of this finance in Section 2.4 below.

Countries vary in how they report contributions to MDBs in their BRs, with some reporting core (non-climate-specific) contributions to MDBs, some attempting to calculate and report only the climate-specific portion of their contribution, and others doing both. This results in wide variances in amounts reported. Since our analysis used MDB outflows attributed back to contributor countries, we subtracted MDB inflows reported in BRs except where it was clear that it was to a climate-specific MDB window or trust fund, not to the MDB's core resources. 


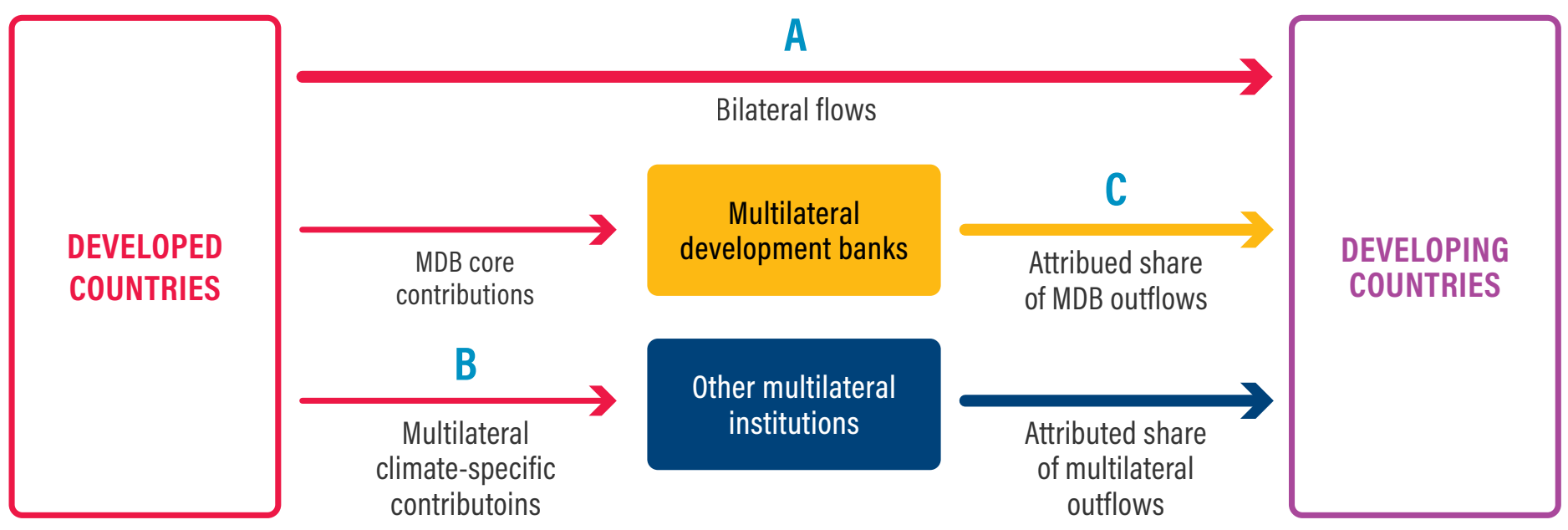

Note: $\mathrm{MDB}=$ multilateral development bank.

Source: WRI authors.

We outline specific changes in detail under the "Reporting errors and corrections" headers in the following subsections. As part of WRI's review process, we sent our calculations to all developed country governments included in this analysis, MDBs, and other institutions involved in climate finance reporting. When countries or institutions notified us of errors or issues in how we used their reporting, we made efforts to adjust and correct these, which are also detailed in the following sections.

\subsection{Bilateral Climate Finance}

\section{Sources}

Data from Table 7: Provision of Public Financial Support: Summary Information and Table $7(\mathrm{~b})$ : Provision of Public Financial Support: Contributions through Bilateral, Regional and Other Channels in Annex II Parties' CTFs submitted as part of their second (2013 and 2014), third (2015 and 2016), and fourth (2017 and 2018) BRs (UNFCCC 2016, 2018b, 2020)

- SCF 2016 (covering 2013 and 2014 data) and 2018 (covering 2015 and 2016 data) BA reports (SCF 2016, 2018)
EU budget shares, 2013-18 (EU 2014, 2015, 2016, 2017, 2018, 2019)

Oxfam Climate Finance Shadow Reports for grant shares of bilateral finance, 2016-18 (Carty et al. 2020)

Data gaps

At the time of publication, the United States had not submitted its third or fourth BRs. For 2015-16, numbers reported in the 2018 BA were used, which were based on preliminary data provided by the United States (SCF 2018). At the time of writing, there were no sources of U.S. data through the UNFCCC available for 2017 and 2018, so we did not include data on U.S. bilateral climate finance in those years. For the United States, the average for 2016-18 is its 2016 finance only, which may be an overestimate since U.S. bilateral climate finance contributions may have decreased in 2017 and 2018 (Thwaites 2018, 2019).

Adjustments

For each country, we counted only the "climatespecific" total contributions reported through bilateral, regional, and other channels. For 2013-16, where there was a discrepancy between the BRs and the BAs, we used corrected data from the BAs. This raw data is shown in Table 3. 
The European Union is a Party to the UNFCCC, and it disburses climate finance itself (in addition to contributions from its member states). The European Union submits its own BR. Because the EU budget, and therefore its climate finance, comes from its member states' budgetary contributions, we allocated to each member state a proportion of their share of the EU budget (see Table 2). EU bilateral climate finance is allocated to the European countries based on their shares of the EU budget. EU climate finance comes partly from the core EU budget and partly from the European Development Fund (EU Council 2018). We used each member state's EU budget shares for the corresponding years to attribute EU climate finance to individual countries. A relatively small amount of climate finance reported in the EU BRs (less than $\$ 200$ million annually) is excluded from our final calculations because it is attributable to non-Annex II countries that are EU member states. Bilateral climate finance flows after these adjustments are shown in Table 4 and Figure 3.

All EU climate finance is earmarked as bilateral in its second and third BRs. However, within Table 7(b) (bilateral climate finance), the European Union also reports on its climate finance from the European Investment Bank (EIB), which is an MDB. The climate finance via the EIB is therefore subtracted from the European Union's total bilateral climate finance in 2013-16. In its fourth BR, the European Union correctly reports its climate finance through the EIB in Table 7(a) (multilateral climate finance), and adjustments are detailed in Section 2.3 on multilateral climate finance below.

To account for qualitative differences in climate finance provided, we also included a column in Table 4 showing the share of bilateral grant-based finance provided by each country in the 2016-18 period, based on data kindly provided by Oxfam, as used in their Climate Finance Shadow Report (Carty et al. 2020). We then shaded Figure 3's post-Paris bars by the proportion of grant-based finance provided (in quintiles, with those providing 81-100 percent grants shaded darkest, and those providing $0-20$ percent grants shaded lightest). Because the United States has not reported for the years 2017 and 2018, its grant share was based on its 2016 data only.

\section{Reporting errors and corrections}

Germany (second and third BRs) and Luxembourg (second BR) did not convert any of their contributions in their CTFs from euros to U.S. dollars, as required in the CTFs. We used converted data from the 2016 and 2018 BAs instead.

- Luxembourg appears to report both commitments and disbursements for some of the same projects in the same year in its CTFs, which would double count the amounts. The government of Luxembourg did not respond to our review process or requests for clarification on this. The discrepancy in any single year was $\$ 10$ million at most. We did not correct this because other countries may also be double counting commitments and disbursements across years. This warrants further scrutiny (see Section 2.1, Methodological Challenges).

Switzerland (fourth BR) reported mobilized private climate finance in the bilateral table $(7[\mathrm{~b}])$ in the years 2017-18. We subtracted these amounts from Switzerland's total bilateral climate finance for 2017 and 2018 because our analysis does not include mobilized private climate finance.

Several countries included climate finance to Annex I Parties in their BRs. It is not clear whether these countries can be defined as developing countries and, hence, whether climate finance channeled to them should be counted towards the $\$ 100$ billion goal (see Box 2). However, we did not correct for potential reporting mistakes made in the bilateral table (7[b]) because countries do not report breakdowns consistently.

Several countries included contributions to multilateral channels explicitly listed in Table 7(a) as bilateral contributions in Table 7 (b). It is not possible to correct for this mistake, however, because countries do not consistently report their bilateral contributions in a disaggregated way. In cases where countries reported multilateral finance in the bilateral finance table, they do not appear to also report these contributions in the multilateral table (7[a]), so there was low likelihood of double counting.

During the review process, representatives from New Zealand notified us that due to the timing of the biennial reporting, they were unable to attribute a 
climate-specific proportion of some contributions to multilateral institutions and instead reported them in full as core/general; however, our methodology did not count these because we focused on climatespecific amounts. Other countries may have taken similar approaches, and this could result in not fully capturing some climate-relevant contributions to multilateral institutions.

Table 2 | Contributions to the EU Budget, Annex II Countries (Percent)

\begin{tabular}{|c|c|c|c|c|c|c|}
\hline & 2013 & 2014 & 2015 & 2016 & 2017 & 2018 \\
\hline Austria & 2.4 & 2.3 & 2.1 & 2.6 & 2.6 & 2.7 \\
\hline Belgium & 3.2 & 3.1 & 3.1 & 3.6 & 3.1 & 3.1 \\
\hline Denmark & 2.1 & 1.9 & 1.8 & 1.8 & 2.0 & 2.1 \\
\hline Finland & 1.6 & 1.5 & 1.5 & 1.8 & 1.7 & 1.7 \\
\hline France & 17.6 & 16.8 & 16.0 & 18.3 & 17.1 & 16.8 \\
\hline Germany & 21.0 & 22.2 & 20.5 & 19.0 & 20.6 & 20.7 \\
\hline Greece & 1.4 & 1.6 & 1.0 & 1.4 & 1.3 & 1.2 \\
\hline Ireland & 1.2 & 1.2 & 1.3 & 1.6 & 1.9 & 1.9 \\
\hline Italy & 12.7 & 12.3 & 12.0 & 13.2 & 12.6 & 12.5 \\
\hline Luxembourg & 0.2 & 0.2 & 0.3 & 0.3 & 0.3 & 0.3 \\
\hline Netherlands & 3.8 & 5.5 & 4.9 & 2.3 & 3.6 & 4.0 \\
\hline Portugal & 1.3 & 1.4 & 1.3 & 1.5 & 1.4 & 1.4 \\
\hline Spain & 8.3 & 8.6 & 7.4 & 8.9 & 8.5 & 8.4 \\
\hline Sweden & 3.0 & 3.3 & 3.0 & 2.4 & 2.8 & 2.7 \\
\hline United Kingdom & 11.7 & 9.7 & 15.4 & 12.0 & 11.1 & 11.0 \\
\hline $\begin{array}{l}\text { Total Annex II } \\
\text { countries }^{\mathrm{a}}\end{array}$ & 91.5 & 91.6 & 91.6 & 90.7 & 90.6 & 90.5 \\
\hline
\end{tabular}

Note: a. The remaining share is from EU member states that are Annex I but not Annex II Parties: Bulgaria, Croatia, Cyprus, Czechia, Estonia, Hungary, Latvia, Lithuania, Malta, Poland, Romania, Slovakia, and Slovenia.

Source: EU 2014, 2015, 2016, 2017, 2018, 2019. 
Table 3 | Raw Bilateral Climate Finance as Reported to the UNFCCC (U.S. Dollars, Millions)

\begin{tabular}{|c|c|c|c|c|c|c|c|}
\hline & 2013 & 2014 & 2015 & 2016 & 2017 & 2018 & TOTAL 2013-18 \\
\hline Australia & 198.71 & 74.23 & 90.11 & 100.21 & 120.21 & 117.43 & 700.89 \\
\hline Austria & 122.82 & 132.35 & 121.38 & 135.20 & 119.79 & 216.40 & 847.94 \\
\hline Belgium & 58.51 & 53.14 & 44.18 & 52.31 & 91.47 & 75.57 & 375.17 \\
\hline Canada & 59.02 & 68.12 & 38.60 & 46.69 & 216.75 & 397.86 & 827.04 \\
\hline Denmark & 176.61 & 209.98 & 137.41 & 148.37 & 145.87 & 172.03 & 990.27 \\
\hline European Union & $3,998.33$ & $3,680.26$ & $4,204.68$ & $5,174,65$ & $3,182.31$ & $3,131,63$ & $23,371.86$ \\
\hline Finland & 42.14 & 58.94 & 42.73 & 29.02 & 37.60 & 30.39 & 240.82 \\
\hline France & $2,968.63$ & $3,657.06$ & $2,961.45$ & $3,473.95$ & $4,263.71$ & $5,292,64$ & $22,617.44$ \\
\hline Germany & $2,212,49$ & $2,496.43$ & $7,792.86$ & $8,837.73$ & $7,018.26$ & $7,033.61$ & $35,391.38$ \\
\hline Greece & 0.04 & 0.00 & 0.25 & 0.26 & 0.09 & 0.00 & 0.64 \\
\hline Iceland & 0.87 & 3.72 & 10.24 & 10.80 & 14.21 & 16.97 & 56.81 \\
\hline Ireland & 44.56 & 42.42 & 38.04 & 53.87 & 61.69 & 71.22 & 311.80 \\
\hline Italy & 61.55 & 33.86 & 197.26 & 136.43 & 367.02 & 293.36 & $1,089.48$ \\
\hline Japan $^{\mathrm{a}}$ & $8,072.52$ & $8,211.65$ & $8,838.37$ & $10,697.52$ & $9,554.28$ & $10,822.16$ & $56,196.50$ \\
\hline Luxembourg & 31.01 & 41.96 & 30.89 & 47.01 & 31.42 & 45.90 & 228.19 \\
\hline Netherlands & 284.98 & 386.78 & 324.31 & 256.80 & 312.97 & 415.17 & $1,981.01$ \\
\hline New Zealand & 34.98 & 59.45 & 40.27 & 34.61 & 27.86 & 43.02 & 240.19 \\
\hline Norway & $1,026.13$ & 526.35 & 354.50 & 290.51 & 469.00 & 833.54 & $3,500.03$ \\
\hline Portugal & 21.21 & 12.22 & 4.68 & 2.21 & 2.44 & 1.94 & 44.70 \\
\hline Spain & 337.30 & 523.85 & 498.26 & 550.13 & 473.14 & 675.27 & $3,057.95$ \\
\hline Sweden & 270.71 & 283.56 & 303.89 & 325.80 & 376.83 & 499.84 & $2,060.63$ \\
\hline Switzerland & 184.02 & 201.93 & 173.23 & 202.32 & 238.17 & 340.41 & $1,340.08$ \\
\hline United Kingdom & 716.98 & 773.85 & $1,168.90$ & $1,054.86$ & 962.90 & $1,268.34$ & $5,945.83$ \\
\hline United States $^{\mathrm{b}}$ & 2,219.99 & $2,328.59$ & $2,502.99$ & $1,897,60$ & Not reported ${ }^{b}$ & Not reported ${ }^{b}$ & $8,949.17^{b}$ \\
\hline $\begin{array}{l}\text { Total Annex II } \\
\text { countries }\end{array}$ & $23,144.11$ & $23,860.70$ & $29,919.48$ & $33,558.86$ & $28,088.00$ & $31,794.69$ & $170,365.84$ \\
\hline
\end{tabular}

Notes: a. Japan included coal-related finance in their climate finance reporting to the United Nations Framework Convention on Climate Change (UNFCCC).

b. At the time of writing, the United States had not submitted reporting on its 2017 and 2018 climate finance to the UNFCCC, so the total for the United States is for $2013-16$ only.

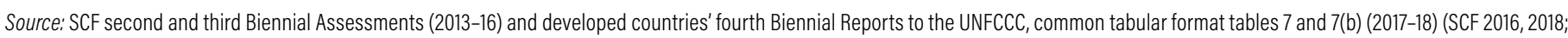
UNFCCC 2020) 
Table 4 | Bilateral Climate Finance after the EU Allocation (U.S. Dollars, Millions)

\begin{tabular}{|c|c|c|c|c|c|c|c|c|c|c|}
\hline & & & & & & & TOTAL & $\begin{array}{r}\text { ANNUAL } \\
\text { AVERAGE } \\
\text { PRE-PARIS }\end{array}$ & $\begin{array}{r}\text { ANNUAL } \\
\text { AVERAGE } \\
\text { POST-PARIS }\end{array}$ & $\begin{array}{r}\text { SHARE OF } \\
\text { GRANT } \\
\text { FINANCE } \\
\text { POST-PARIS }\end{array}$ \\
\hline & 2013 & 2014 & 2015 & 2016 & 2017 & 2018 & 2013-18 & 2013-15 & 2016-18 & 2016-18 \\
\hline Australia & 198.71 & 74.23 & 90.11 & 100.21 & 120.21 & 117.43 & 700.89 & 121.02 & 112.61 & $99 \%$ \\
\hline Austria & 153.55 & 153.00 & 156.69 & 213.72 & 202.53 & 300.95 & $1,180.45$ & 154.41 & 239.07 & $25 \%$ \\
\hline Belgium & 99.49 & 80.97 & 96.31 & 161.03 & 190.12 & 172.65 & 800.57 & 92.26 & 174.60 & $98 \%$ \\
\hline Canada & 59.02 & 68.12 & 38.60 & 46.69 & 216.75 & 397.86 & 827.04 & 55.25 & 220.43 & $38 \%$ \\
\hline Denmark & 203.50 & 227.04 & 167.68 & 202.73 & 209.51 & 237.80 & $1,248.26$ & 199.41 & 216.68 & $98 \%$ \\
\hline Finland & 62.63 & 72.41 & 67.95 & 83.38 & 91.70 & 83.63 & 461.70 & 66.36 & 86.24 & $49 \%$ \\
\hline France & $3,194.01$ & $3,807.88$ & $3,230.50$ & $4,026.63$ & $4,807.88$ & $5,818.76$ & $24,885.65$ & $3,396.73$ & 4,884.42 & $3 \%$ \\
\hline Germany & $2,481.40$ & $2,695.72$ & $8,137,58$ & $9,411.55$ & $7,673.81$ & $7,681.86$ & $38,081.93$ & $4,420.25$ & $8,255.74$ & $36 \%$ \\
\hline Greece & 17.97 & 14.36 & 17.07 & 42.54 & 41.46 & 37,58 & 170.98 & 15.46 & 40.53 & $100 \%$ \\
\hline Iceland & 0.87 & 3.72 & 10.24 & 10.80 & 14.21 & 16.97 & 56.81 & 4.94 & 13.99 & $100 \%$ \\
\hline Ireland & 59.93 & 53.19 & 59.90 & 102.19 & 122.15 & 130.72 & 528.08 & 56.58 & 118.35 & $100 \%$ \\
\hline Italy & 224.18 & 144.28 & 399.05 & 535.08 & 767.99 & 684.82 & $2,755.40$ & 245.39 & 662.63 & $63 \%$ \\
\hline Japana & $8,072.52$ & $8,211.65$ & $8,838.37$ & 10,697.52 & $9,554.28$ & $10,822.16$ & $56,196.50$ & $8,374.18$ & $10,357.99$ & $12 \%$ \\
\hline Luxembourg & 33.57 & 43.76 & 35.93 & 56.07 & 40.97 & 55.29 & 265.59 & 37.52 & 50.78 & $100 \%$ \\
\hline Netherlands & 333.64 & 436.15 & 406.71 & 326.26 & 427.53 & 540.44 & $2,470.73$ & 387.95 & 431.41 & $100 \%$ \\
\hline New Zealand & 34.98 & 59.45 & 40.27 & 34.61 & 27.86 & 43.02 & 240.19 & 44.90 & 35.16 & $100 \%$ \\
\hline Norway & $1,026.13$ & 526.35 & 354.50 & 290.51 & 469.00 & 833.54 & $3,500.03$ & 635.66 & 531.02 & $75 \%$ \\
\hline Portugal & 37.86 & 24.79 & 26.54 & 47.51 & 47.00 & 45.78 & 229.47 & 28.59 & 46.76 & $100 \%$ \\
\hline Spain & 443.58 & 601.05 & 622.70 & 818.92 & 743.64 & 938.33 & $4,168.22$ & 549.11 & 833.63 & $26 \%$ \\
\hline Sweden & 309.13 & 313.18 & 354.34 & 398.28 & 465.94 & 584.40 & $2,425.26$ & 322.91 & 482.87 & $100 \%$ \\
\hline Switzerland & 184.02 & 201.93 & 173.23 & 202.32 & 214.60 & 228.23 & $1,204.32$ & 186.39 & 215.05 & $98 \%$ \\
\hline United Kingdom & 866.80 & 860.93 & $1,427.86$ & $1,417,27$ & $1,316.14$ & $1,612.82$ & $7,501.82$ & $1,039.95$ & $1,448.74$ & $91 \%$ \\
\hline United States $^{b}$ & 2,219.99 & $2,328.59$ & $2,502.99$ & $1,897,60$ & $x^{b}$ & $x^{b}$ & $8,949.17$ & $2,350.52$ & $1,897.60$ & $34 \%$ \\
\hline $\begin{array}{l}\text { Total Annex II } \\
\text { countries }\end{array}$ & $20,317.48$ & $21,002.75$ & $27,255.12$ & $31,123.44$ & $27,765.29$ & $31,385.01$ & $158,849.08$ & $22,779.60$ & $30,091.25$ & \\
\hline
\end{tabular}

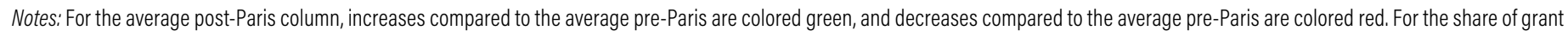
finance post-Paris column, coloring denotes grant share: 100 percent is shaded dark blue and 0 percent is light blue, with gradations by percentage in between.

a. Japan included coal-related finance in their climate finance reporting to the United Nations Framework Convention on Climate Change (UNFCCC).

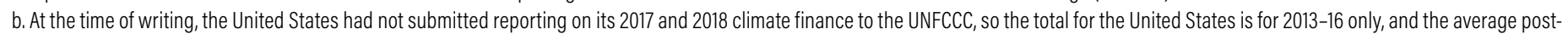
Paris for the United States is its contribution in 2016 only. The U.S. grant share is for its 2016 finance only.

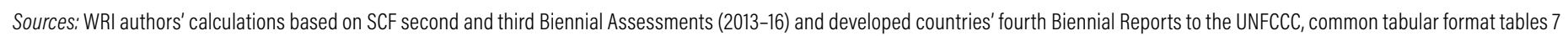

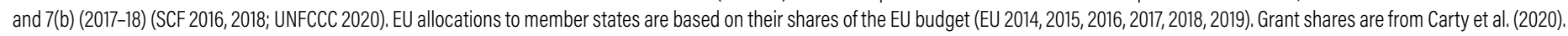


12

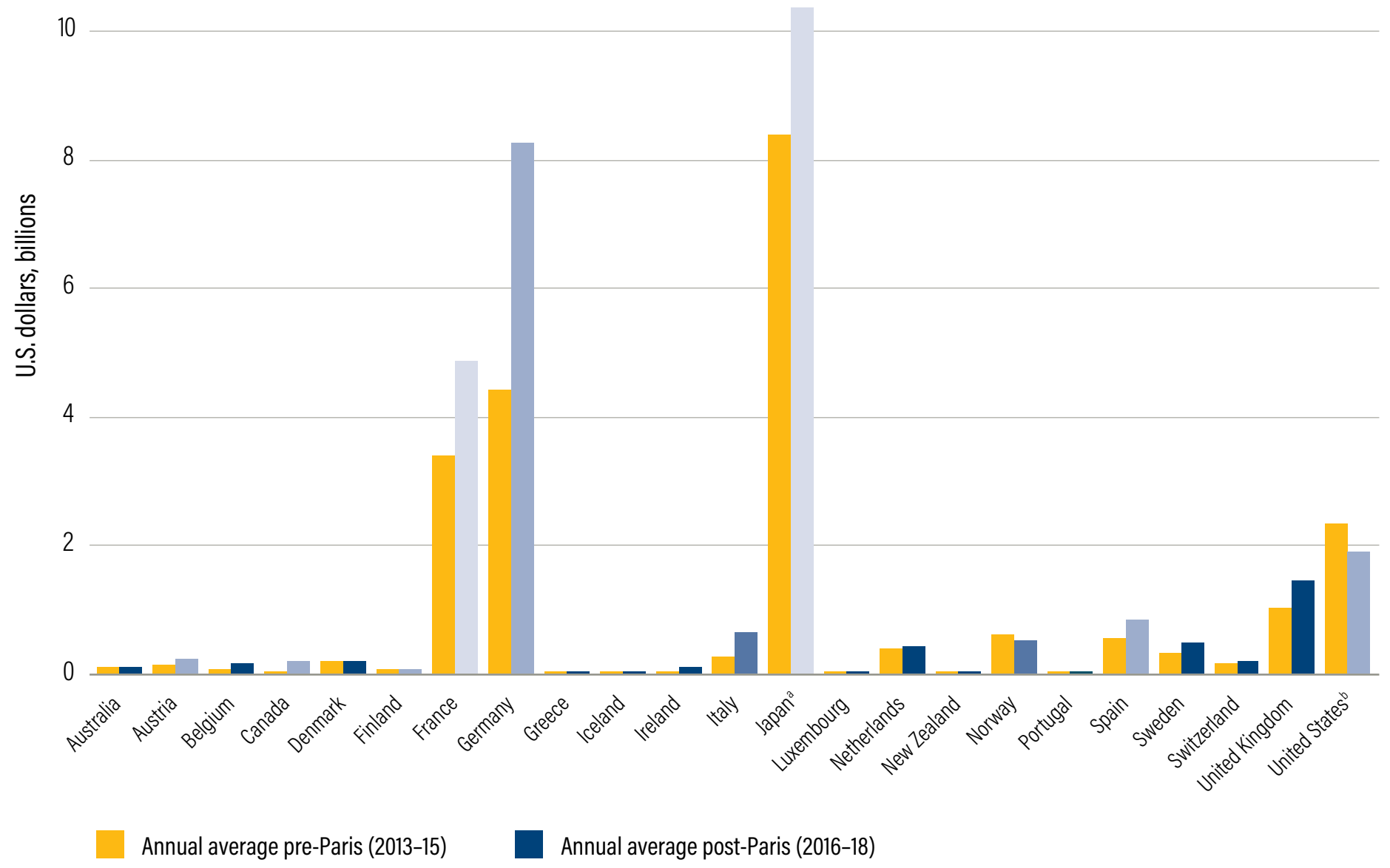

Notes: Post-Paris bar shading denotes the share of grants in climate finance provided by quintile: darker is higher share, lighter is lower share. a. Japan included coal-related finance in their climate finance reporting to the United Nations Framework Convention on Climate Change (UNFCCC).

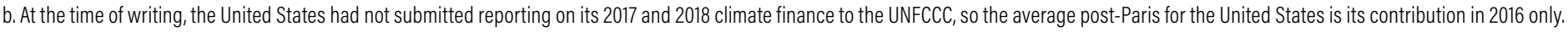

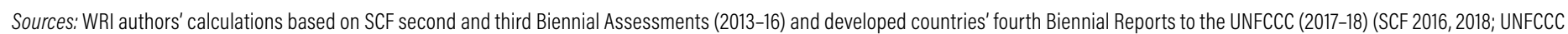
2020). EU allocations to member states are based on their shares of the EU budget (EU 2014, 2015, 2016, 2017, 2018, 2019). Grant shares are from Carty et al. (2020).

\subsection{Multilateral Climate Finance Inflows to Institutions Other than MDBs}

\section{Sources}

Data from Table 7(a): Provision of Public Financial Support: Contribution through Multilateral Channels in Annex II Parties' CTFs submitted as part of their second (2013 and 2014), third (2015 and 2016), and fourth (2017 and 2018) BRs (UNFCCC

2016, 2018b, 2020)
SCF 2016 (covering 2013 and 2014 data) and 2018 (covering 2015 and 2016 data) BA reports (SCF 2016, 2018)

EU budget shares, 2013-18 (EU 2014, 2015, 2016, 2017, 2018, 2019)

Oxfam Climate Finance Shadow Report for grant shares of bilateral finance, 2016-18 (Carty et al. 2020) 
Data gaps

At the time of publication, the United States had not submitted its third or fourth BRs. For 2015-16, numbers reported in the $2018 \mathrm{BA}$ are used, which were based on preliminary data provided by the United States (SCF 2018). At the time of writing, no U.S. data was available for 2017 and 2018 through the UNFCCC, so we did not include data on U.S. multilateral climate finance in those years. For the United States, the average for 2016-18 is its 2016 finance only, which may be an overestimate because U.S. multilateral climate finance contributions decreased in 2017 and 2018 (Thwaites 2018, 2019).

\section{Adjustments}

For each country, we counted only the "climatespecific" contributions through multilateral channels, such as multilateral climate funds (such as the GCF, Adaptation Fund, or the Least Developed Countries Fund), regional development banks and specialized UN bodies. For the years 2013-16, where there was a discrepancy between the BRs and the BAs, we used corrected data from the BAs. This raw data is shown in Table 5 .

\section{Because we calculated MDB finance separately} (see Section 2.4 on MDBs below), for any country that included data in its BR on climate-specific contributions to the seven MDBs that receive contributions from Annex II countries and report to the OECD DAC, ${ }^{4}$ we subtracted this from the multilateral total to avoid double counting. Table 7 (b) includes the subheading "Multilateral financial institutions," which includes entries for the African Development Bank (AfDB), Asian Development Bank (ADB), European Bank for Reconstruction and Development (EBRD), IFC, Inter-American Development Bank, World Bank, and "Other." We subtracted any climate-specific finance reported for these six entities, as well as climatespecific finance reported to the Asian Infrastructure Investment Bank (AIIB), which is not included as a predefined option in Table 7 (b) but was included in the BRs by some countries. The "Other" category should include only regional development banks, trust funds connected to MDBs, and other multilateral financial institutions, however, some countries appeared to report contributions to the above MDBs under this subcategory (for example, contributions to the International Development Association (IDA) and the International Bank for Reconstruction and
Development (IBRD) should be reported under "World Bank," but some countries reported them as "Other" multilateral contributions). Amounts reported as climate-specific contributions to the main MDBs are subtracted, but any contributions to specialized trust funds administered by the MDBs are left in because these are not included in MDB climate finance figures in the OECD CRS, which is the source used to calculate MDB climate finance outflows. Multilateral climate finance inflows after these adjustments are shown in Table 6 and Figure 4.

To account for qualitative differences in climate finance provided, we also included a column in Table 6 showing the share of multilateral grant-based finance provided by each country in the 2016-18 period, based on data kindly provided by Oxfam, as used in their Climate Finance Shadow Report (Carty et al. 2020). We then shaded Figure 4's post-Paris bars by the proportion of grant-based finance provided (in quintiles, with those providing 81-100 percent grants shaded darkest, and those providing 0-20 percent grants shaded lightest). Because the United States had not reported for the years 2017 and 2018, its grant share was based on its 2016 data only.

\section{Reporting errors and corrections}

Germany (second and third BRs) and Luxembourg (second BR) did not convert any of their contributions in their CTFs from euros to U.S. dollars, as required in the CTFs. We used converted data from the 2016 and 2018 BAs instead.

- France (third BR) and Italy (second BR) included different entries under the national currency and U.S. dollars portions of Table 7 (a) rather than including the equivalent converted values. We used converted data from the 2016 and 2018 BAs instead.

Because the "multilateral financial institutions" data is not broken out in the BA technical report, for the purposes of subtracting MDB contributions from overall multilateral finance, where France, Germany, Italy, and Luxembourg did not include conversions, OECD conversion rates for the corresponding years were used (OECD 2021b).

- Luxembourg reports both commitments and disbursements in the same year for the same multilateral institutions in its CTFs, which double counts the amounts. In some cases, Luxembourg reported the total amount committed to a multilateral channel in multiple years, which would also result 
in double counting. These result in discrepancies of up to $\$ 80$ million in a single year. These issues were not corrected in the BA, so we manually corrected this data.

In its first and second BRs, the United States did not report any MDB climate-specific contributions, so no subtractions of MDB climate finance were necessary for calculating multilateral climate finance flows excluding MDBs. At the time of writing, the United States had not submitted its third or fourth BRs. We therefore used provisional data provided by the United States to the UNFCCC for the 2018 BA for 2015 and 2016 (SCF 2018), and we assumed, in keeping with its previous reporting, that the United States also did not include climate-specific MDB contributions in this data.

Table 5 | Raw Multilateral Climate Finance Inflows as Reported to the UNFCCC (U.S. Dollars, Millions)

\begin{tabular}{|c|c|c|c|c|c|c|c|}
\hline & 2013 & 2014 & 2015 & 2016 & 2017 & 2018 & TOTAL 2013-18 \\
\hline Australia & 37.64 & 67.86 & 146.58 & 106.98 & 96.00 & 145.69 & 600.76 \\
\hline Austria & 65.97 & 55.04 & 66.23 & 74.23 & 61.05 & 65.97 & 388.49 \\
\hline Belgium & 46.41 & 75.04 & 8.01 & 59.32 & 26.82 & 19.69 & 235.29 \\
\hline Canada & 8.38 & 2.20 & 2.94 & 142.69 & 60.88 & 47.05 & 264.15 \\
\hline Denmark & 33.11 & 33.75 & 42.13 & 43.73 & 58.91 & 61.41 & 273.04 \\
\hline European Union & 0.00 & 0.00 & 0.00 & 0.00 & $2,976.73$ & $3,509.37$ & $6,486.10$ \\
\hline Finland & 81.79 & 95.19 & 85.31 & 18.57 & 96.97 & 24.59 & 402.42 \\
\hline France & 14.44 & 14.43 & 255.70 & 219.07 & 668.45 & 715.34 & $1,887,43$ \\
\hline Germany & 335.57 & 315.15 & 176.72 & 394.46 & 332.17 & 455.42 & $2,009.48$ \\
\hline Greece & 0.00 & 0.00 & 0.00 & 0.00 & 5.08 & 4.45 & 9.53 \\
\hline Iceland & 6.56 & 7.18 & 0.64 & 0.43 & 2.55 & 2.56 & 19.92 \\
\hline Ireland & 0.80 & 2.31 & 1.87 & 4.42 & 15.66 & 19.94 & 45.01 \\
\hline Italy & 153.86 & 185.83 & 241.67 & 154.40 & 345.29 & 240.24 & $1,321.29$ \\
\hline Japan & 0.00 & 0.00 & 122.55 & 188.00 & 246.12 & 202.70 & 759.38 \\
\hline Luxembourg & 6.73 & 12.45 & 58.69 & 96.78 & 80.10 & 83.32 & 338.07 \\
\hline Netherlands & 95.49 & 135.62 & 243.44 & 256.13 & 152.18 & 239.04 & $1,121,90$ \\
\hline New Zealand & 0.00 & 0.00 & 2.53 & 0.54 & 0.00 & 1.11 & 4.18 \\
\hline Norway & 243.51 & 440.87 & 185.43 & 132.57 & 0.00 & 0.00 & $1,002.38$ \\
\hline Portugal & 0.00 & 0.00 & 2.22 & 0.00 & 0.00 & 0.00 & 2.22 \\
\hline Spain & 0.66 & 52.78 & 12.35 & 81.09 & 142.24 & 134.37 & 423.50 \\
\hline Sweden & 70.63 & 19.61 & 59.81 & 119.34 & 180.79 & 184.80 & 634.98 \\
\hline Switzerland & 97.15 & 97.08 & 131.17 & 136.32 & 131.99 & 112.10 & 705.79 \\
\hline United Kingdom & 498.74 & 687.02 & 746.09 & 361.61 & 198.58 & 289.86 & $2,781.90$ \\
\hline United States $^{a}$ & 476.48 & 442.34 & 463.70 & $1,372.60$ & Not reported ${ }^{a}$ & Not reported ${ }^{a}$ & $2,755.12^{\mathrm{a}}$ \\
\hline Total & 2,273.91 & $2,741.75$ & $3,055.77$ & $3,963.29$ & $5,878.56$ & $6,559.04$ & $24,472.33$ \\
\hline
\end{tabular}

Notes: a. At the time of writing, the United States had not submitted reporting on its 2017 and 2018 climate finance to the UNFCCC, so the total for the United States is for $2013-16$ only. 
Table 6 | Multilateral Climate Finance Inflows after the EU Allocation to Member States and Excluding MDBs (U.S. Dollars, Millions)

\begin{tabular}{|c|c|c|c|c|c|c|c|c|c|c|}
\hline & & & & & & & TOTAL & $\begin{array}{r}\text { ANNUAL } \\
\text { AVERAGE } \\
\text { PRE-PARIS }\end{array}$ & $\begin{array}{r}\text { ANNUAL } \\
\text { AVERAGE } \\
\text { POST-PARIS }\end{array}$ & $\begin{array}{r}\text { SHARE OF } \\
\text { GRANT } \\
\text { FINANCE } \\
\text { POST-PARIS }\end{array}$ \\
\hline & 2013 & 2014 & 2015 & 2016 & 2017 & 2018 & 2013-18 & 2013-15 & 2016-18 & 2016-18 \\
\hline Australia & 37.64 & 14.15 & 93.61 & 59.77 & 42.48 & 37.16 & 284.82 & 48.47 & 46.47 & $100 \%$ \\
\hline Austria & 11.95 & 1.53 & 27.76 & 36.52 & 17.87 & 4.81 & 100.44 & 13.75 & 19.73 & $77 \%$ \\
\hline Belgium & 46.41 & 75.04 & 8.01 & 59.32 & 26.82 & 19.69 & 235.29 & 43.15 & 35.28 & $100 \%$ \\
\hline Canada & 6.44 & 2.20 & 2.94 & 142.69 & 60.88 & 47.05 & 262.21 & 3.86 & 83.54 & $100 \%$ \\
\hline Denmark & 12.87 & 10.84 & 31.45 & 29.74 & 47.72 & 43.38 & 176.00 & 18.38 & 40.28 & $100 \%$ \\
\hline Finland & 37.63 & 68.16 & 60.09 & 6.02 & 6.87 & 10.97 & 189.74 & 55.29 & 7.95 & $45 \%$ \\
\hline France & 14.44 & 14.43 & 154.31 & 119.30 & 566.05 & 299.82 & $1,168.35$ & 61.06 & 328.39 & $64 \%$ \\
\hline Germany & 335.57 & 309.84 & 176.72 & 394.46 & 332.17 & 455.42 & $2,004.17$ & 274.04 & 394.01 & $100 \%$ \\
\hline Greece & 0.00 & 0.00 & 0.00 & 0.00 & 0.31 & 0.43 & 0.74 & 0.00 & 0.25 & $100 \%$ \\
\hline Iceland & 5.57 & 6.17 & 0.64 & 0.43 & 0.82 & 1.23 & 14.86 & 4.13 & 0.83 & $100 \%$ \\
\hline Ireland & 0.80 & 2.31 & 1.87 & 4.42 & 8.38 & 9.20 & 26.99 & 1.66 & 7.33 & $99 \%$ \\
\hline Italy & 30.46 & 61.95 & 146.19 & 95.45 & 249.30 & 131.11 & 714.46 & 79.53 & 158.62 & $100 \%$ \\
\hline Japan & 0.00 & 0.00 & 122.55 & 188.00 & 246.12 & 202.70 & 759.38 & 40.85 & 212.28 & $100 \%$ \\
\hline Luxembourg & 4.75 & 3.84 & 16.51 & 15.08 & 18.91 & 20.64 & 79.72 & 8.36 & 18.21 & $51 \%$ \\
\hline Netherlands & 54.18 & 41.35 & 54.62 & 94.58 & 86.06 & 83.31 & 414.09 & 50.05 & 87.98 & $100 \%$ \\
\hline New Zealand & 0.00 & 0.00 & 2,53 & 0.54 & 0.00 & 1.11 & 4.18 & 0.84 & 0.55 & $100 \%$ \\
\hline Norway & 153.37 & 175.41 & 154.84 & 79.79 & 0.00 & 0.00 & 563.42 & 161.21 & 26.60 & $100 \%$ \\
\hline Portugal & 0.00 & 0.00 & 2.22 & 0.00 & 0.00 & 0.00 & 2.22 & 0.74 & 0.00 & $\mathrm{~N} / \mathrm{A}$ \\
\hline Spain & 0.66 & 52.78 & 5.99 & 8.73 & 26.88 & 60.50 & 155.54 & 19.81 & 32.04 & $74 \%$ \\
\hline Sweden & 70.63 & 19.61 & 59.81 & 119.34 & 115.02 & 107.67 & 492.08 & 50.02 & 114.01 & $100 \%$ \\
\hline Switzerland & 32.34 & 22.75 & 63.82 & 72.08 & 72.61 & 33.65 & 297.26 & 39.64 & 59.45 & $100 \%$ \\
\hline United Kingdom & 498.74 & 687.02 & 746.09 & 361.61 & 198.58 & 289.86 & $2,781.90$ & 643.95 & 283.35 & $100 \%$ \\
\hline United States $^{a}$ & 476.48 & 442.34 & 463.70 & $1,372.60$ & $x^{a}$ & $x^{a}$ & $2,755.12^{\mathrm{a}}$ & 460.84 & $1,372.60^{\mathrm{a}}$ & $56 \%^{a}$ \\
\hline $\begin{array}{l}\text { Total Annex II } \\
\text { countries }\end{array}$ & $1,830.92$ & $2,011.72$ & $2,396.27$ & $3,260.47$ & $2,123.86$ & $1,859.72$ & $13,482.97$ & $2,079.64$ & $2,414.69$ & \\
\hline
\end{tabular}

Notes: For the average post-Paris column, increases compared to average pre-Paris are colored green, and decreases compared to average pre-Paris are colored red. For the share of grant finance post-Paris column, coloring denotes grant share: 100 percent is shaded dark blue and 0 percent is light blue, with gradations by percentage in between. Portugal did not report any multilateral finance in the period 2016-18, so grant share is not included.

a. At the time of writing, the United States had not submitted reporting on its 2017 and 2018 climate finance to the UNFCCC, so the total for the United States is for 2013-16 only and the average postParis for the United States is its contribution in 2016 only. The U.S. grant share is for its 2016 finance only.

Sources: WRI calculations based on SCF second and third Biennial Assessments (2013-16); and developed countries' fourth Biennial Reports to the UNFCCC, common tabular format tables 7 and 7(b) (2017-18) (SCF 2016, 2018; UNFCCC 2020). EU allocations to member states are based on their shares of the EU budget (EU 2014, 2015, 2016, 2017, 2018, 2019). Grant shares are from Carty et al. (2020). 
Figure 4 | Multilateral Climate Finance Inflows (Excluding MDBs) by Country, Annual Average Pre- and Post-Paris Agreement

\section{4}

1.2

1.0

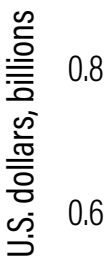

0.4

0.2

0.0

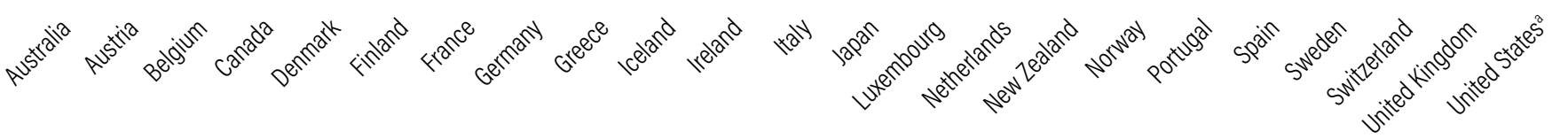

Annual average pre-Paris (2013-15)

Annual average post-Paris (2016-18)

Notes: Post-Paris bar shading denotes the share of grants in climate finance provided by quintile: darker is higher share, lighter is lower share.

a. The United States had not submitted reporting on its 2017 and 2018 climate finance to the United Nations Framework Convention on Climate Change (UNFCCC), so the average post-Paris for the United States is its contribution in 2016 only.

Sources: WRI authors, based on SCF second and third Biennial Assessments (2013-16) and developed countries' fourth Biennial Reports to the UNFCCC (2017-18) (SCF 2016, 2018; UNFCCC 2020). EU allocations to member states are based on their shares of the EU budget (EU 2014, 2015, 2016, 2017, 2018, 2019). Grant shares are from Carty et al. (2020). 


\subsection{MDB Outflows Attributed to Developed Country Contributors}

\section{Sources}

OECD DAC CRS multilateral climate finance outflows (OECD 2021a)

- Shareholder allocations from MDBs and subunits, detailed below (not all Annex II countries are shareholders in all MDBs; dashes in tables show nonshareholders)

\section{Adjustments}

Counted MDB climate finance outflows from own resources reported to the OECD CRS for the seven MDBs that receive contributions from Annex II countries. Contributions from externally managed resources, such as multilateral climate funds that work through MDBs and MDB special trust funds and windows, are not included in this data set and are captured in BRs and as such, are counted as other multilateral climate finance inflows. This raw data is shown in Table 20.

For each MDB, climate finance outflows are attributed to developed countries based on their percentage shareholding in each MDB, as a proxy for inflows (see Tables 7-19). This is a similar approach as used in Westphal et al. (2015). Where MDBs have units with different shareholder compositions (for example, the
IDA, IBRD, and IFC in the World Bank Group), we attributed outflows back to contributors based on each unit's different shareholdings, where available. Since other countries, including developing countries, are also shareholders in MDBs, the sum of developed countries' shares does not equate to MDBs' total reported climate finance. This differs from the OECD's approach, which uses a more complex methodology developed by the Technical Working Group of 19 bilateral climate finance providers (OECD 2015, 2019, 2020; TWG 2015). This methodology accounts for the effect contributor country credit ratings have on MDBs' own credit ratings and therefore their ability to raise additional capital from bond markets. This accounting approach gives developed countries, which generally have stronger credit ratings, a greater attributed share of MDB outflows and has been controversial with developing countries. The underlying data sets used for such calculations are also not publicly available. For these reasons, we used the simpler shareholding approach to calculate developed countries' shares of MDB climate finance outflows. Specific details for each MDB's shareholding calculation are detailed below. MDB climate finance outflows allocated to countries according to this approach are shown in Table 21 and Figure 5. 


\section{AFRICAN DEVELOPMENT BANK}

Climate finance is allocated to individual developed countries based on the AfDB's subscribed capital shares and its African Development Fund (AfDF) subscribed capital shares (AfDB 2014, 2015, 2016, 2017, 2018, 2019).
The AfDB holds around 0.4 percent of the subscribed capital shares in the AfDF. Due to this small shareholding, we did not allocate AfDB's shares in the AfDF back to shareholder countries.

Table 7 | AfDB Subscribed Capital Shares, Annex I| Countries (Percent)

\section{3}

2014

2016

2017

2018

Australia

Austria

$0.45 \quad 0.45$

Belgium

0.64

3.84

Canada

Denmark

1.19

0.49

3.78

4.13

Germany

Greece

Iceland

Ireland

Italy

Japan

Luxembourg

Netherlands

New Zealand

Norway

Portugal

Spain

Sweden

Switzerland

United Kingdom

United States

Total Annex II countries

$\begin{array}{ll}2.44 & 2.44 \\ 5.53 & 5.53\end{array}$

0.64

0.45

0.64

3.82

1.19

$\begin{array}{ll}- & 0.20 \\ & \end{array}$

0.86

0.86

1.17

0.24

1.09

1.55

1.48

1.69

6.60

37.17

$1.17 \quad 1.17$

1.17

0.24

1.09

1.56

1.48

1.69

6.60

37.36

2.44

2.43

5.50

0.20

0.87

0.49

3.76

4.13

1.18

49

0.49

0.49

0.49

76

3.77

4.15

3.77

3.80

4.18

5.53

50

$-$

-

1.16

0.24

1.08

1.55

1.47

1.75

6.57

37.29

\begin{tabular}{rr}
1.18 \\
0.24 & 0.24 \\
1.07 \\
1.5 & 1.58 \\
1.47 & 1.47 \\
1.75 & 1.76 \\
\hline 57 & 6.58 \\
\hline
\end{tabular}

1.18

2.43

5.51

2.44

2.45

5.55

0.20

0.89

Note: Dashes denote where countries were not shareholders.

Sources: AfDB 2014, 2015, 2016, 2017, 2018, 2019. 


\section{3}

2014

2015

2016

2017

2018

Australia

Austria

1.73

Belgium

1.96

Canada

6.93

Denmark

2.58

European Union

0.00

Finland

1.99

France

10.01

Germany

10.06

1.86

1.83

2.01

1.83

1.96

1.93

2.05

2.01

2.00

1.97

6.85

6.73

2.53

6.73

2.49

6.66

6.56

2.49

0.00

0.00

2.15

2.11

10.11

9.93

10.30

10.12

0.00

2.47

2.43

Greece

Iceland

Ireland

Italy

Japan

6.53

10.86

Luxembourg

0.00

Netherlands

4.14

New Zealand

Norway

Portugal

4.35

0.63

Spain

2.46

Sweden

4.89

Switzerland

3.49

United Kingdom

8.79

11.53

92.94

6.46

10.57

0.06

4.24

2.11

0.00

0.00

2.04

9.98

9.93

2.07

9.94

10.49

10.32

10.12

$-$

United States

Total Annex II countries

4.56

0.66

$2.14 \quad 2.27$

5.05

3.54

9.98

10.03

93.13

\begin{tabular}{l}
4.48 \\
0.65 \\
\hline 2.27 \\
4.96
\end{tabular}

4.48

0.65

2.27

6.35

10.38

6.39

6.29

10.38

0.05

4.16

10.16

10.23

0.08

4.20

Note: Dashes denote where countries were not shareholders.

Sources: AfDB 2014, 2015, 2016, 2017, 2018, 2019. 


\section{ASIAN DEVELOPMENT BANK}

Climate finance is allocated to individual developed countries based on the ADB's subscribed capital shares (ADB 2014a, 2015a, 2016a, 2017a, 2018a, 2019a) and the its Asian Development Fund (ADF) effective amounts (ADB 2014b, 2015b, 2016b, 2017b, 2018b, 2019b).

Table 9 | ADB Subscribed Capital Shares, Annex I| Countries (Percent)

\begin{tabular}{|c|c|c|c|c|c|c|}
\hline & 2013 & 2014 & 2015 & 2016 & 2017 & 2018 \\
\hline Australia & 5.81 & 5.81 & 5.79 & 5.79 & 5.79 & 5.77 \\
\hline Austria & 0.34 & 0.34 & 0.34 & 0.34 & 0.34 & 0.34 \\
\hline Belgium & 0.34 & 0.34 & 0.34 & 0.34 & 0.34 & 0.34 \\
\hline Canada & 5.25 & 5.25 & 5.24 & 5.23 & 5.23 & 5.22 \\
\hline Denmark & 0.34 & 0.34 & 0.34 & 0.34 & 0.34 & 0.34 \\
\hline Finland & 0.34 & 0.34 & 0.34 & 0.34 & 0.34 & 0.34 \\
\hline France & 2.34 & 2.34 & 2.33 & 2.33 & 2.33 & 2.32 \\
\hline Germany & 4.34 & 4.35 & 4.33 & 4.33 & 4.33 & 4.32 \\
\hline Greece & - & - & - & - & - & - \\
\hline Iceland & - & - & - & - & - & . \\
\hline Ireland & 0.34 & 0.34 & 0.34 & 0.34 & 0.34 & 0.34 \\
\hline Italy & 1.82 & 1.82 & 1.81 & 1.81 & 1.81 & 1.80 \\
\hline Japan & 15.67 & 15.68 & 15.62 & 15.61 & 15.61 & 15.57 \\
\hline Luxembourg & 0.34 & 0.34 & 0.34 & 0.34 & 0.34 & 0.34 \\
\hline Netherlands & 1.03 & 1.03 & 1.03 & 1.03 & 1.03 & 1.02 \\
\hline New Zealand & 1.54 & 1.54 & 1.54 & 1.54 & 1.54 & 1.53 \\
\hline Norway & 0.34 & 0.34 & 0.34 & 0.34 & 0.34 & 0.34 \\
\hline Portugal & 0.11 & 0.11 & 0.11 & 0.11 & 0.11 & 0.34 \\
\hline Spain & 0.34 & 0.34 & 0.34 & 0.34 & 0.34 & 0.34 \\
\hline Sweden & 0.34 & 0.34 & 0.34 & 0.34 & 0.34 & 0.34 \\
\hline Switzerland & 0.59 & 0.59 & 0.58 & 0.58 & 0.58 & 0.58 \\
\hline United Kingdom & 2.05 & 2.05 & 2.05 & 2.04 & 2.04 & 2.04 \\
\hline United States & 15.56 & 15.57 & 15.51 & 15.61 & 15.61 & 15.57 \\
\hline Total Annex II countries & 59.19 & 59.21 & 59.01 & 59.05 & 59.05 & 59.15 \\
\hline
\end{tabular}

Note: Dashes denote where countries were not shareholders.

Sources: ADB 2014a, 2015a, 2016a, 2017a, 2018a, 2019a.. 


\begin{tabular}{|c|c|c|c|c|c|c|}
\hline & 2013 & 2014 & 2015 & 2016 & 2017 & 2018 \\
\hline Australia & 7.67 & 7.65 & 7.57 & 7.54 & 7.94 & 7.90 \\
\hline Austria & 0.88 & 0.88 & 0.87 & 0.87 & 0.87 & 0.87 \\
\hline Belgium & 0.78 & 0.78 & 0.77 & 0.77 & 0.73 & 0.72 \\
\hline Canada & 6.25 & 6.24 & 6.17 & 6.15 & 6.05 & 6.02 \\
\hline Denmark & 0.74 & 0.81 & 0.80 & 0.80 & 0.76 & 0.78 \\
\hline European Union & - & - & - & - & - & - \\
\hline Finland & 0.61 & 0.61 & 0.60 & 0.60 & 0.60 & 0.59 \\
\hline France & 4.37 & 4.36 & 4.31 & 4.30 & 4.19 & 4.17 \\
\hline Germany & 5.97 & 5.96 & 5.89 & 5.87 & 5.75 & 5.72 \\
\hline Greece & - & - & - & - & - & - \\
\hline Iceland & - & - & - & - & - & - \\
\hline Ireland & 0.30 & 0.30 & 0.30 & 0.30 & 0.32 & 0.32 \\
\hline Italy & 3.69 & 3.69 & 3.65 & 3.63 & 3.55 & 3.53 \\
\hline Japan & 38.32 & 38.25 & 37.85 & 37.70 & 38.33 & 38.15 \\
\hline Luxembourg & 0.17 & 0.17 & 0.17 & 0.17 & 0.18 & 0.18 \\
\hline Netherlands & 2.44 & 2.43 & 2.41 & 2.40 & 2.30 & 2.29 \\
\hline New Zealand & 0.56 & 0.56 & 0.55 & 0.55 & 0.54 & 0.55 \\
\hline Norway & 0.91 & 0.91 & 0.91 & 0.91 & 0.92 & 0.92 \\
\hline Portugal & 0.29 & 0.29 & 0.29 & 0.29 & 0.27 & 0.27 \\
\hline Spain & 1.33 & 1.32 & 1.31 & 1.69 & 1.41 & 1.41 \\
\hline Sweden & 1.51 & 1.50 & 1.49 & 1.48 & 1.46 & 1.45 \\
\hline Switzerland & 1.22 & 1.22 & 1.21 & 1.20 & 1.20 & 1.20 \\
\hline United Kingdom & 4.99 & 4.98 & 4.93 & 4.91 & 5.03 & 5.01 \\
\hline United States & 13.43 & 13.41 & 14.31 & 14.26 & 13.45 & 13.84 \\
\hline Total Annex II countries & 96.42 & 96.33 & 96.37 & 96.39 & 95.85 & 95.90 \\
\hline
\end{tabular}

Note: Dashes denote where countries were not shareholders. Sources: ADB 2014a, 2015a, 2016a, 2017a, 2018a, 2019a.. 


\section{ASIAN INFRASTRUCTURE INVESTMENT BANK}

Climate finance is allocated to individual developed countries based on the AIIB's subscribed capital shares (AIIB 2021).

Table 11 | AllB Subscribed Capital Shares, Annex || Countris (Percent)

SINCE 2016

\begin{tabular}{lc} 
Australia & 3.81 \\
\hline Austria & 0.52 \\
\hline Belgium & 0.29 \\
\hline Canada & 1.03 \\
\hline Denmark & 0.38 \\
\hline Finland & 0.32 \\
\hline France & 3.49 \\
\hline Germany & 4.63 \\
\hline Greece & 0.01 \\
\hline Iceland & 0.02 \\
\hline Ireland & 0.14 \\
\hline Italy & 2.66 \\
\hline Japan & - \\
\hline Luxembourg & 0.07 \\
\hline Netherlands & 1.07 \\
\hline New Zealand & 0.48 \\
\hline Norway & 0.57 \\
\hline Portugal & 0.07 \\
\hline Spain & 1.82 \\
\hline Sweden & 0.65 \\
\hline Switzerland & 0.73 \\
\hline United Kingdom & 3.16 \\
\hline United States & - \\
\hline TotaAnn & \\
\hline
\end{tabular}

Total Annex II countries

25.91

Note: Dashes denote where countries were not shareholders

Sources: AllB 2021.

\section{EUROPEAN BANK FOR RECONSTRUCTION AND DEVELOPMENT}

Climate finance is allocated to individual developed countries based on the EBRD's subscribed capital shares (EBRD n.d.).

The European Union and the EIB are shareholders of the EBRD. To avoid double counting, we did not allocate EBRD climate finance shares back to the European Union and the EIB because they report themselves on these climate-specific contributions.

Table 12 | EBRD Subscribed Capital Shares, Annex I| Countries (Percent)

\begin{tabular}{|c|c|}
\hline & SINCE JULY 2013 \\
\hline Australia & 1.01 \\
\hline Austria & 2.30 \\
\hline Belgium & 2.30 \\
\hline Canada & 3.43 \\
\hline Denmark & 1.21 \\
\hline Finland & 1.26 \\
\hline France & 8.60 \\
\hline Germany & 8.60 \\
\hline Greece & 0.66 \\
\hline Iceland & 0.10 \\
\hline Ireland & 0.30 \\
\hline Italy & 8.60 \\
\hline Japan & 8.60 \\
\hline Luxembourg & 0.20 \\
\hline Netherlands & 2.50 \\
\hline New Zealand & 0.04 \\
\hline Norway & 1.26 \\
\hline Portugal & 1.29 \\
\hline Spain & 3.43 \\
\hline Sweden & 2.30 \\
\hline Switzerland & 2.30 \\
\hline United Kingdom & 8.60 \\
\hline United States & 10.09 \\
\hline
\end{tabular}

Total Annex II countries

78.99 


\section{EUROPEAN INVESTMENT BANK}

Climate finance is allocated to individual developed countries based on the EIB's subscribed capital shares (EIB 2019).

Table 13 | ElB Subscribed Capital Shares, Annex II Countries (Percent)

\section{3-18}

Australia

Austria

2.22

Belgium

Canada

Denmark

Finland

France

Germany

Greece

Iceland

Ireland

Italy

Japan

Luxembourg

Netherlands

New Zealand

Norway

Portugal

Spain

Sweden

\section{Switzerland}

United Kingdom

United States

Total Annex II countries ${ }^{a}$

Notes: Dashes denote where countries were not shareholders.

a. The remaining share is from EU member states that are Annex I but not Annex II Parties: Bulgaria, Croatia, Cyprus, Czechia, Estonia, Hungary, Latvia, Lithuania, Malta, Poland, Romania, Slovakia, and Slovenia.

Source: ElB 2019. 
INTER-AMERICAN DEVELOPMENT BANK GROUP (IDBG)

Climate finance is allocated to individual developed countries based on subscribed capital shares for the IDB (IDB 2014a, 2015a, 2016a, 2017a, 2018,
2019) and its Fund for Special Operations (FSO)

(IDB 2014b, 2015b, 2016b, 2017b), Inter-American Investment Corporation (IIC) (2014, 2015, 2016, 2017), and IDB Invest (2018, 2019).

Table 14 | IDB Ordinary Capital Subscribed Capital Shares, Annex II Countries (Percent)

\section{3} 2014

2015

2016

2017

Australia

Austria

Belgium

Canada

European Union

Finland

France

Germany

Greece

Iceland

Ireland

Italy

Japan

Luxembourg

Netherlands

New Zealand

Norway

Portugal

Spain

Sweden

Switzerland

United Kingdom

United States

Total Annex II countries

Note: Dashes denote where countries were not shareholders.

Sources: ADB 2014a, 2015a, 2016a, 2017a, 2018a, 2019a..

$\begin{array}{llllll}0.16 & 0.16 & 0.16 & 0.16 & 0.16 & 0.16 \\ 0.32 & 0.33 & 0.33 & 0.33 & 0.33 & 0.33 \\ 6.29 & 4.93 & 4.00 & 4.00 & 3.97 & 3.97 \\ 0.17 & 0.17 & 0.17 & 0.17 & 0.17 & 0.17 \\ 0.16 & 0.16 & 0.16 & 0.16 & 0.16 & 0.16 \\ 1.85 & 1.88 & 1.90 & 1.90 & 1.90 & 1.90 \\ 1.85 & 1.88 & 1.90 & 1.90 & 1.91 & 1.91\end{array}$

\section{8}


Table 15 | IDB FSO Subscribed Capital Shares, Annex II Countries (Percent)

\section{3}

2014

2015

2016

Australia

Austria

0.21

Belgium

0.44

Canada

3.21

Denmark

0.21

0.21

0.21

0.21

0.44

0.44

0.44

3.22

3.23

3.23

0.21

0.21

0.21

European Union

Finland

0.19

0.19

0.19

0.19

France

2.27

Germany

2.36

2.27

2.27

2.27

2.36

2.36

2.36

Greece

Iceland

Ireland

Italy

Japan

2.22

2.22

2.22

2.22

6.09

6.09

6.09

6.09

Luxembourg

Netherlands

0.36

0.36

0.36

0.36

New Zealand

\begin{tabular}{ll}
\hline Norway & 0.21 \\
\hline Portugal & 0.08 \\
\hline
\end{tabular}

Spain

0.21

0.21

0.21

0.21

0.08

2.21

0.08

0.08

0.08

Sweden

0.41

2.21

2.21

2.21

Switzerland

United Kingdom

0.66

0.41

0.41

0.41

United States

1.80

0.66

0.66

0.66

49.57

1.80

1.80

1.80

Total Annex II countries

72.48

49.57

49.57

49.56

72.49

72.49

72.49

Note: Dashes denote where countries were not shareholders..

Sources: IDB 2014b, 2015b, 2016b, 2017b. 
Table 16 | IIC and IDB Invest Subscribed Capital Shares, Annex II Countries (Percent)

\section{3}

Australia

Austria

Belgium

Canada

Denmark

European Union

Finland

France

Germany

Greece

Iceland

Ireland

Italy

Japan

Luxembourg

Netherlands

New Zealand

Norway

Portugal

Spain

Sweden

Switzerland

United Kingdom

United States

Total Annex II countries

Note: Dashes denote where countries were not shareholde

Sources: IIC 2014, 2015, 2016, 2017; IDB Invest 2018, 2019.

\section{4}

2015

2016

2017

2018

0.49

0.49

0.59

0.59

0.59

0.58

0.24

0.24

0.13

0.11

0.11

0.12

0.00

1.52

0.21

0.26

2.70

2.70

2.73

$1.52 \quad 0.85$

0.71

0.71

0.70

$-$

0.56

0.56

3.07

1.89

3.06

1.89

0.67

0.68

0.68

0.66

2.29

1.90

1.90

1.90

1.06

0.88

0.88

0.90 


\section{WORLD BANK GROUP (WBG)}

The World Bank Group comprises four institutions that provide climate finance: the IBRD, IDA, IFC, and Multilateral Investment Guarantee Agency (MIGA). MIGA only provides guarantees, and the OECD CRS records MIGA's climate finance data under private mobilized finance, which is beyond the scope of this report. WBG institutions all have separate capital shareholder profiles. For each year, we used shareholder data from June (IBRD 2013, 2014, 2015, 2016, 2017, 2018; IDA 2013, 2014, 2015, 2016, 2017 , 2018; IFC 2013, 2014, 2015, 2016, 2017, 2018).

Table 17 | IBRD Subscribed Shares, Annex II Countries (Percent)

\begin{tabular}{|c|c|c|c|c|c|c|}
\hline & 2013 & 2014 & 2015 & 2016 & 2017 & 2018 \\
\hline Australia & 1.49 & 1.50 & 1.44 & 1.45 & 1.42 & 1.39 \\
\hline Austria & 0.68 & 0.69 & 0.67 & 0.67 & 0.66 & 0.64 \\
\hline Belgium & 1.75 & 1.68 & 1.71 & 1.70 & 1.68 & 1.64 \\
\hline Canada & 3.15 & 3.02 & 2.78 & 2.67 & 2.62 & 2.56 \\
\hline Denmark & 0.96 & 0.92 & 0.85 & 0.82 & 0.80 & 0.78 \\
\hline Finland & 0.53 & 0.54 & 0.52 & 0.52 & 0.51 & 0.50 \\
\hline France & 4.22 & 4.26 & 4.13 & 4.14 & 4.06 & 3.97 \\
\hline Germany & 4.73 & 4.79 & 4.61 & 4.42 & 4.33 & 4.24 \\
\hline Greece & 0.09 & 0.09 & 0.08 & 0.08 & 0.08 & 0.15 \\
\hline Iceland & 0.07 & 0.07 & 0.07 & 0.07 & 0.08 & 0.08 \\
\hline Ireland & 0.28 & 0.33 & 0.33 & 0.34 & 0.35 & 0.34 \\
\hline Italy & 2.54 & 2.64 & 2.59 & 2.65 & 2.84 & 2.78 \\
\hline Japan & 8.94 & 8.57 & 7.89 & 7.58 & 7.42 & 7.26 \\
\hline Luxembourg & 0.09 & 0.09 & 0.08 & 0.10 & 0.10 & 0.10 \\
\hline Netherlands & 2.14 & 2.16 & 1.99 & 2.10 & 2.06 & 2.01 \\
\hline New Zealand & 0.39 & 0.37 & 0.47 & 0.45 & 0.44 & 0.43 \\
\hline Norway & 0.66 & 0.67 & 0.61 & 0.61 & 0.60 & 0.59 \\
\hline Portugal & 0.30 & 0.28 & 0.26 & 0.25 & 0.27 & 0.33 \\
\hline Spain & 1.71 & 2.19 & 2.11 & 2.02 & 1.98 & 1.94 \\
\hline Sweden & 0.92 & 0.93 & 0.91 & 0.90 & 0.89 & 0.87 \\
\hline Switzerland & 1.66 & 1.69 & 0.65 & 1.59 & 1.55 & 1.52 \\
\hline United Kingdom & 4.22 & 4.26 & 4.13 & 4.14 & 4.06 & 3.97 \\
\hline United States & 16.05 & 15.87 & 17.07 & 17.58 & 17.25 & 16.88 \\
\hline Total Annex II countries & 57.57 & 57.61 & 55.95 & 56.85 & 56.05 & 54.97 \\
\hline
\end{tabular}

Sources: IIC 2014, 2015, 2016, 2017; IDB Invest 2018, 2019. 
Table 18 | IDA Subscribed Shares, Annex II Countries (Percent)

\begin{tabular}{|c|c|c|c|c|c|c|}
\hline & 2013 & 2014 & 2015 & 2016 & 2017 & 2018 \\
\hline Australia & 1.82 & 1.81 & 1.85 & 1.84 & 1.84 & 1.89 \\
\hline Austria & 1.11 & 1.11 & 1.19 & 1.26 & 1.26 & 1.35 \\
\hline Belgium & 1.81 & 1.80 & 1.83 & 1.82 & 1.82 & 1.84 \\
\hline Canada & 4.56 & 4.51 & 4.57 & 4.51 & 4.51 & 4.55 \\
\hline Denmark & 1.51 & 1.52 & 1.47 & 1.47 & 1.47 & 1.48 \\
\hline Finland & 0.74 & 0.74 & 0.79 & 0.78 & 0.78 & 0.78 \\
\hline France & 7.09 & 7.08 & 7.06 & 7.03 & 7.03 & 7.08 \\
\hline Germany & 10.73 & 10.72 & 10.47 & 10.42 & 10.42 & 10.24 \\
\hline Greece & 0.09 & 0.09 & 0.08 & 0.08 & 0.08 & 0.08 \\
\hline Iceland & 0.03 & 0.03 & 0.03 & 0.03 & 0.03 & 0.04 \\
\hline Ireland & 0.28 & 0.28 & 0.29 & 0.29 & 0.29 & 0.30 \\
\hline Italy & 4.26 & 4.28 & 3.78 & 3.77 & 3.77 & 3.96 \\
\hline Japan & 18.23 & 18.05 & 17.64 & 17.95 & 17.95 & 17.43 \\
\hline Luxembourg & 0.13 & 0.13 & 0.11 & 0.13 & 0.13 & 0.15 \\
\hline Netherlands & 3.66 & 3.67 & 3.58 & 3.56 & 3.56 & 3.63 \\
\hline New Zealand & 0.14 & 0.15 & 0.14 & 0.14 & 0.14 & 0.14 \\
\hline Norway & 1.62 & 1.61 & 1.59 & 1.57 & 1.57 & 1.62 \\
\hline Portugal & 0.13 & 0.13 & 0.11 & 0.11 & 0.11 & 0.12 \\
\hline Spain & 1.41 & 1.41 & 1.26 & 1.74 & 1.74 & 1.73 \\
\hline Sweden & 3.33 & 3.31 & 3.27 & 3.24 & 3.24 & 3.30 \\
\hline Switzerland & 1.76 & 1.75 & 2.07 & 2.05 & 2.05 & 2.15 \\
\hline United Kingdom & 11.14 & 11.49 & 12.23 & 11.61 & 11.61 & 11.98 \\
\hline United States & 20.75 & 20.61 & 20.60 & 20.54 & 20.54 & 19.81 \\
\hline Total Annex II countries & 96.29 & 96.27 & 96.01 & 95.96 & 95.96 & 95.65 \\
\hline
\end{tabular}

Sources: IDA 2013, 2014, 2015, 2016, 2017, 2018. 
Table 19 | IFC Subscribed Shares, Annex II Countries (Percent)

\begin{tabular}{|c|c|c|c|c|c|c|}
\hline & 2013 & 2014 & 2015 & 2016 & 2017 & 2018 \\
\hline Australia & 1.97 & 1.89 & 1.84 & 1.84 & 1.84 & 1.84 \\
\hline Austria & 0.82 & 0.79 & 0.77 & 0.77 & 0.77 & 0.77 \\
\hline Belgium & 2.11 & 2.02 & 1.97 & 1.97 & 1.97 & 1.97 \\
\hline Canada & 3.38 & 3.25 & 3.17 & 3.17 & 3.17 & 3.17 \\
\hline Denmark & 0.77 & 0.74 & 0.72 & 0.72 & 0.72 & 0.72 \\
\hline Finland & 0.65 & 0.63 & 0.61 & 0.61 & 0.61 & 0.61 \\
\hline France & 5.04 & 4.84 & 4.72 & 4.72 & 4.72 & 4.72 \\
\hline Germany & 5.36 & 5.15 & 5.02 & 5.02 & 5.02 & 5.02 \\
\hline Greece & 0.29 & 0.28 & 0.27 & 0.27 & 0.27 & 0.27 \\
\hline Iceland & - & - & - & - & - & - \\
\hline Ireland & 0.05 & 0.05 & 0.05 & 0.05 & 0.05 & 0.05 \\
\hline Italy & 3.38 & 3.25 & 3.17 & 3.17 & 3.17 & 3.17 \\
\hline Japan & 5.87 & 6.49 & 6.33 & 6.33 & 6.33 & 6.33 \\
\hline Luxembourg & 0.09 & 0.09 & 0.08 & 0.08 & 0.08 & 0.08 \\
\hline Netherlands & 2.34 & 2.24 & 2.19 & 2.19 & 2.19 & 2.19 \\
\hline New Zealand & 0.15 & 0.14 & 0.14 & 0.14 & 0.14 & 0.14 \\
\hline Norway & 0.73 & 0.70 & 0.69 & 0.69 & 0.69 & 0.69 \\
\hline Portugal & 0.35 & 0.33 & 0.32 & 0.32 & 0.32 & 0.32 \\
\hline Spain & 1.54 & 1.48 & 1.44 & 1.44 & 1.44 & 1.44 \\
\hline Sweden & 1.12 & 1.07 & 1.05 & 1.05 & 1.05 & 1.05 \\
\hline Switzerland & 1.83 & 1.76 & 1.72 & 1.72 & 1.72 & 1.72 \\
\hline United Kingdom & 5.04 & 4.84 & 4.72 & 4.72 & 4.72 & 4.72 \\
\hline United States & 23.69 & 22.75 & 22.19 & 22.19 & 22.19 & 22.19 \\
\hline Total Annex II countries & 66.57 & 64.78 & 63.18 & 63.18 & 63.18 & 63.18 \\
\hline
\end{tabular}

Note: Dashes denote where countries were not shareholders.

Sources: IFC 2013, 2014, 2015, 2016, 2017, 2018. 
Table 20 | MDB Climate Finance Outflows as Reported in the OECD DAC CRS (U.S. Dollars, Millions)

\begin{tabular}{|c|c|c|c|c|c|c|c|c|}
\hline MDB & $\begin{array}{l}\text { MDB UNIT } \\
\text { (IF APPLICABLE) }\end{array}$ & 2013 & 2014 & 2015 & 2016 & 2017 & 2018 & TOTAL \\
\hline \multirow[t]{2}{*}{ AfDB } & African Development Fund & 729.81 & 710.94 & 383.93 & 199.94 & 544.88 & 422.16 & $2,991.66$ \\
\hline & African Development Bank & 243.20 & 825.40 & 459.82 & 731.07 & 727.88 & 859.78 & $3,847,16$ \\
\hline \multirow[t]{2}{*}{ ADB } & $\begin{array}{l}\text { Asian Development Bank } \\
\text { Concessional }\end{array}$ & 938.44 & 702.52 & 329.83 & 296.46 & 550.81 & 868.35 & $3,686.42$ \\
\hline & $\begin{array}{l}\text { Asian Development Bank Ordinary } \\
\text { Capital Resources }\end{array}$ & $1,780.43$ & $1,419.15$ & $1,564.02$ & $1,847.41$ & $4,010.00$ & $3,619.66$ & $14,240.66$ \\
\hline AllB & $\begin{array}{l}\text { Asian Infrastructure Investment } \\
\text { Bank }\end{array}$ & N/A & N/A & N/A & 362.70 & $1,232.60$ & 951.03 & $2,546.33$ \\
\hline EBRD & $\begin{array}{l}\text { European Bank for } \\
\text { Reconstruction and Development }\end{array}$ & $1,698.34$ & $2,727,52$ & $2,491.05$ & $2,506.56$ & $3,415.15$ & $2,925.96$ & $15,764.57$ \\
\hline \multirow[t]{3}{*}{ EIB } & European Investment Bank & $2,715.77$ & $2,784.20$ & $2,219.04$ & $2,153.84$ & $2,903.20$ & $3,405.01$ & $16,181.06$ \\
\hline & Fund for Special Operations & 27.22 & 65.68 & 191.44 & 383.63 & $N / A$ & $N / A$ & 667.97 \\
\hline & $\begin{array}{l}\text { Inter-American Investment } \\
\text { Corporation and Multilateral } \\
\text { Investment Fund }\end{array}$ & $1,094.68$ & $1,944.81$ & $1,649.46$ & $1,319.78$ & $N / A$ & $N / A$ & $6,008.73$ \\
\hline \multirow[t]{2}{*}{ IDBG } & $\begin{array}{l}\text { Inter-American Development } \\
\text { Bank }\end{array}$ & $N / A$ & N/A & $N / A$ & $N / A$ & $2,968.89$ & $3,283.01$ & $6,251.90$ \\
\hline & IDB Invest & $N / A$ & N/A & N/A & 725.08 & 823.73 & 571.06 & $2,119.87$ \\
\hline \multirow[t]{3}{*}{ WBG } & International Finance Corporation & $1,657.94$ & $1,892.69$ & $1,763.42$ & $2,425.12$ & $3,492.92$ & Not reported & $11,232,08$ \\
\hline & $\begin{array}{l}\text { International Development } \\
\text { Association }\end{array}$ & $2,251.23$ & $4,544.32$ & $2,558.11$ & $2,948.88$ & $5,362.06$ & $6,696.05$ & $24,360.65$ \\
\hline & $\begin{array}{l}\text { International Bank for } \\
\text { Reconstruction and Development }\end{array}$ & $2,692.77$ & $4,346.92$ & $4,307.72$ & $4,898.61$ & $5,182.01$ & $6,908.22$ & $28,336.25$ \\
\hline
\end{tabular}

Note: $\mathrm{MDB}=$ multilateral development bank; $\mathrm{WBG}=$ World Bank Group.

Sources: OECD 2021a. 
Table 21 | MDB Climate Finance Outflows Allocated to Countries (U.S. Dollars, Millions)

\begin{tabular}{|c|c|c|c|c|c|c|c|c|c|}
\hline & & & & & & & TOTAL & $\begin{array}{r}\text { ANNUAL } \\
\text { AVERAGE } \\
\text { PRE-PARIS }\end{array}$ & $\begin{array}{r}\text { ANNUAL } \\
\text { AVERAGE } \\
\text { POST-PARIS }\end{array}$ \\
\hline & 2013 & 2014 & 2015 & 2016 & 2017 & 2018 & 2013-18 & 2013-15 & 2016-18 \\
\hline Australia & 306.27 & 347.02 & 282.60 & 338.17 & 593.49 & 565.95 & $2,433.49$ & 311.96 & 499.20 \\
\hline Austria & 185.99 & 251.06 & 199.88 & 219.04 & 320.23 & 322.93 & $1,499.13$ & 212.31 & 287.40 \\
\hline Belgium & 316.13 & 417.30 & 336.43 & 363.82 & 509.40 & 502.83 & $2,445.92$ & 356.62 & 458.68 \\
\hline Canada & 583.67 & 788.02 & 596.01 & 672.08 & $1,066.31$ & $1,040.35$ & 4,746.45 & 655.90 & 926.25 \\
\hline Denmark & 191.19 & 260.62 & 193.45 & 211.82 & 307.79 & 317.95 & $1,482.83$ & 215.09 & 279.19 \\
\hline Finland & 126.79 & 170.37 & 133.57 & 147.12 & 215.76 & 209.56 & $1,003.18$ & 143.58 & 190.81 \\
\hline France & $1,126.07$ & $1,486.45$ & $1,155.00$ & $1,250.38$ & $1,826.81$ & $1,849.92$ & $8,694.63$ & $1,255.84$ & $1,642.37$ \\
\hline Germany & $1,279.06$ & $1,725.10$ & $1,307.30$ & $1,413.22$ & $2,133.39$ & $2,176.22$ & $10,034.29$ & $1,437.15$ & $1,907.61$ \\
\hline Greece & 53.31 & 65.04 & 53.45 & 55.36 & 75.51 & 76.18 & 378.84 & 57.26 & 69.01 \\
\hline Iceland & 4.19 & 7.00 & 6.25 & 7.00 & 9.59 & 11.02 & 45.04 & 5.81 & 9.20 \\
\hline Ireland & 44.13 & 58.92 & 49.03 & 53.91 & 79.31 & 88.47 & 373.76 & 50.69 & 73.89 \\
\hline Italy & 945.31 & $1,209.44$ & 948.27 & $1,021.21$ & $1,482.29$ & $1,508.02$ & $7,114.54$ & $1,034.34$ & $1,337.17$ \\
\hline Japan & $1,680.92$ & $2,262,64$ & $1,645.38$ & $1,843.97$ & $2,970.47$ & $3,089.61$ & $13,492.98$ & $1,862.98$ & $2,634.68$ \\
\hline Luxembourg & 20.85 & 28.02 & 22.18 & 26.84 & 42.66 & 43.10 & 183.65 & 23.69 & 37.53 \\
\hline Netherlands & 419.16 & 569.64 & 425.63 & 473.89 & 698.01 & 710.13 & $3,296.45$ & 471.48 & 627.34 \\
\hline New Zealand & 49.48 & 52.11 & 53.06 & 62.26 & 106.98 & 105.07 & 428.95 & 51.55 & 91.43 \\
\hline Norway & 138.92 & 206.57 & 144.70 & 161.05 & 251.98 & 250.14 & $1,153.36$ & 163.40 & 221.05 \\
\hline Portugal & 70.48 & 92.71 & 76.62 & 81.64 & 113.83 & 118.43 & 553.71 & 79.94 & 104.63 \\
\hline Spain & 484.26 & 627.42 & 508.45 & 577.53 & 803.23 & 830.22 & $3,831.11$ & 540.04 & 737.00 \\
\hline Sweden & 301.01 & 426.91 & 306.97 & 331.39 & 504.61 & 529.11 & $2,400.00$ & 344.96 & 455.04 \\
\hline Switzerland & 210.01 & 312.87 & 210.84 & 292.06 & 424.51 & 406.39 & $1,856.68$ & 244.57 & 374.32 \\
\hline United Kingdom & $1,193.77$ & $1,650.61$ & $1,258.82$ & $1,337.77$ & $2,006.01$ & $2,114.90$ & $9,561.88$ & $1,367.73$ & $1,819.56$ \\
\hline United States & $2,301.52$ & $3,384.43$ & $2,858.67$ & 3,322.45 & $4,916.92$ & $4,646.95$ & $21,430.94$ & $2,848.21$ & $4,295.44$ \\
\hline Total Annex II countries & $12,032.50$ & $16,400.27$ & $12,772.56$ & $14,263.96$ & $21,459.07$ & $21,513.45$ & $98,441.82$ & $13,735.11$ & $19,078.83$ \\
\hline
\end{tabular}

Note: For the average post-Paris column, increases compared to average pre-Paris are colored green.

Source: WRI calculations based on OECD (2021a) and MDB shareholder data. 


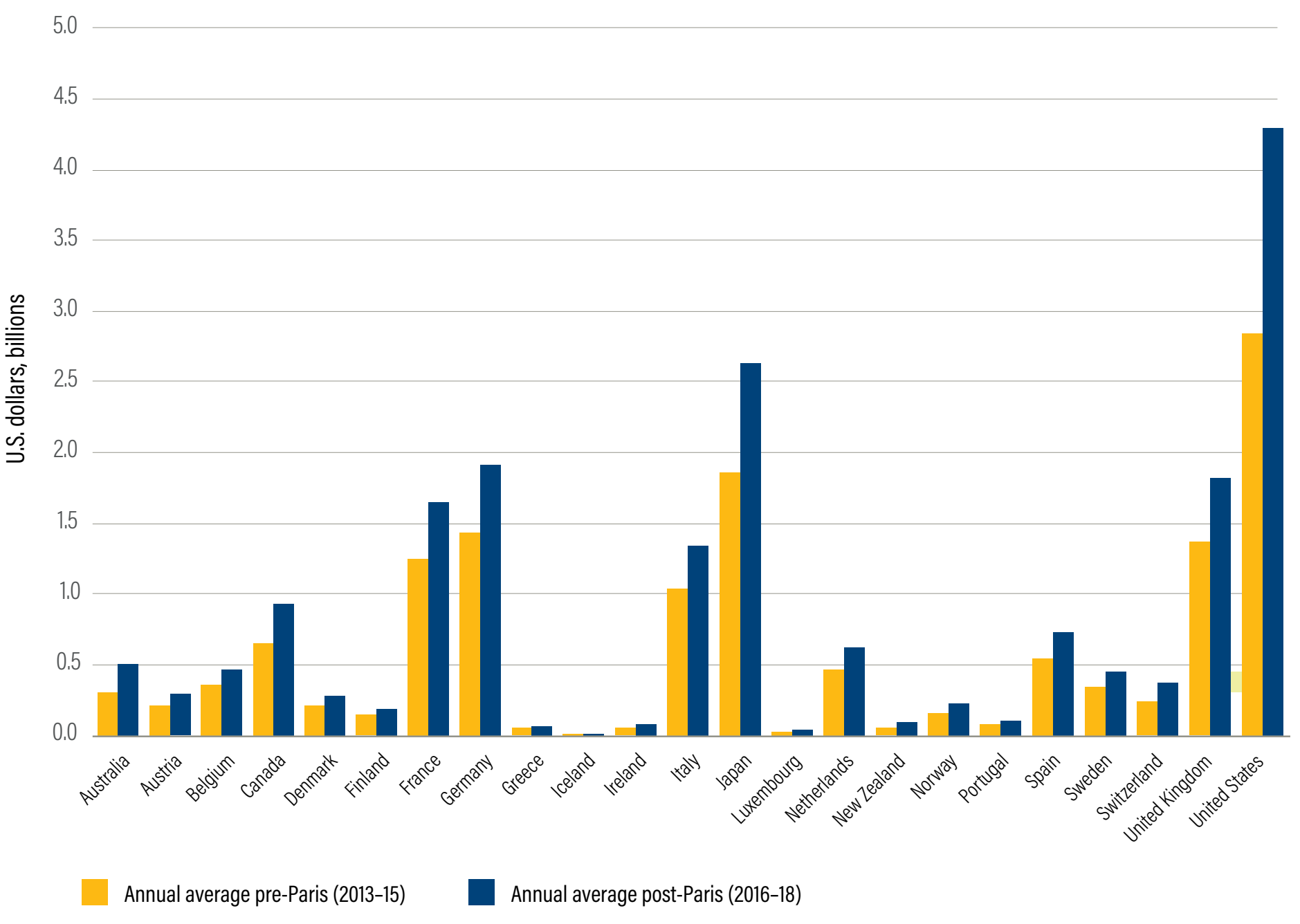

Source: WRI authors based on OECD (2021a) and MDB shareholder data.

\section{ANALYSIS}

\subsection{Total Public Climate Finance}

After performing the adjustments outlined in Section 2 , it is then possible to analyze the breakdown of public climate finance provided by each country each year for the period 2013-18. We presented two ways of looking at the data:

Perspective 1: Climate-specific finance inflows, which include bilateral climate finance and climate-specific contributions to multilateral entities (A + B in Figure 6). This aims to capture each country's direct climate- specific contributions from their national budgets. This is what many governments count in the scope of national climate finance pledges. It does not include core funding provided to MDBs, of which a portion is ultimately used for climate-specific activities.

Perspective 2: Total attributed climate finance, which includes bilateral climate finance, climatespecific contributions to multilateral entities, and the attributed shares of MDB climate finance outflows $(A+B+C$ in Figure 6). This aims to capture how much climate finance each country could ultimately claim credit for towards the $\$ 100$ billion goal. It does not capture the full climate finance outflows from 
non-MDB multilateral entities because complete data for all entities was not available. Instead, we used only inflows to these entities (as with Perspective 1 above), which is an imperfect approach because some multilateral entities can provide more funding as outflows than they receive as inflows (for example, when they make loans from grantbased contributions). In addition, many, if not most, multilateral institutions do not spend the money they receive from governments in the same year as they receive it, so there is a temporal mismatch. Looking at amounts for multiyear periods can help address the latter to some extent.

Below, we show the annual amounts, totals, and averages for the three years before (2013-15) and after (2016-18) the Paris Agreement was finalized at the end of 2015. We present data for both the climate-specific finance inflows perspective (Table 22 and Figure 7) and total attributed climate finance perspective (Table 23 and Figure 8). This provides a snapshot of the public climate finance each developed country has provided, with the pre- and post-Paris averages smoothing out any anomalously high or low years and enabling an assessment of whether each country's climate finance has risen since the Paris Agreement was finalized.
At the time of writing, the United States had still not submitted its third and fourth BRs, and although it supplied data on 2015 and 2016 climate finance to the UNFCCC for the third BA, no reporting was available for 2017 and 2018. Therefore, the U.S. average climate finance for 2016-18 for the inflows perspective is its 2016 finance only. For U.S. average climate finance for 2016-18 for the total attributed climate finance perspective, it is its bilateral and multilateral contributions in 2016 plus its average of MDB climate finance contributions for 2016-18. Using only the 2016 bilateral and multilateral inflows climate finance for its 2016-18 averages may be an overestimate because U.S. bilateral and multilateral fund contributions are likely to have decreased in 2017 and 2018 (Thwaites 2018, 2019).

To account for qualitative differences in climate finance provided, we also included a column in Table 22 and Table 23 showing the share of bilateral and multilateral grantbased finance for the 2016-18 period, based on data kindly provided by Oxfam and used in its Climate Finance Shadow Report (Carty et al. 2020). We also shaded Figure 7 by the proportion of grant-based finance provided (in quintiles, with those providing 81-100 percent grants shaded darkest, and those providing $0-20$ percent grants shaded lightest). Table 24 and Figure 9 show annual averages postParis for each country broken down by the three funding channels, with the bilateral and multilateral portions of the columns also shaded according to their quintile share of grant finance.

Figure 6 | Perspectives for Analyzing Climate Finance Flows

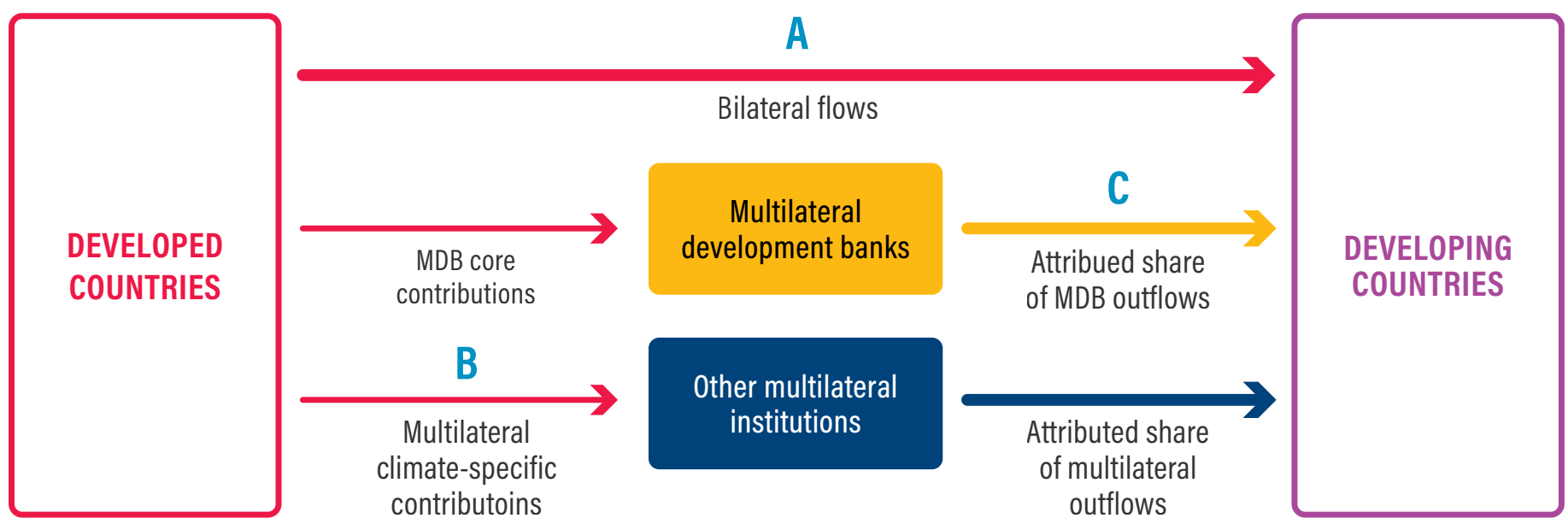

Note: $\mathrm{MDB}=$ multilateral development bank.

Source: Based on OECD (2018b), adapted by WRI. 
Table 22 | Climate-Specific Finance Inflows from Annex II Countries: Bilateral and Multilateral Inflows (U.S. Dollars, Millions)

\begin{tabular}{|c|c|c|c|c|c|c|c|c|c|c|}
\hline & & & & & & & TOTAL & $\begin{array}{r}\text { ANNUAL } \\
\text { AVERAGE } \\
\text { PRE-PARIS }\end{array}$ & $\begin{array}{r}\text { ANNUAL } \\
\text { AVERAGE } \\
\text { POST-PARIS }\end{array}$ & $\begin{array}{r}\text { SHARE OF } \\
\text { GRANT FINANCE } \\
\text { POST-PARIS }\end{array}$ \\
\hline & 2013 & 2014 & 2015 & 2016 & 2017 & 2018 & 2013-18 & 2013-15 & $2016-18$ & 2016-18 \\
\hline Australia & 236.35 & 88.38 & 183.72 & 159.98 & 162.69 & 154.59 & 985.71 & 169.48 & 159.09 & $100 \%$ \\
\hline Austria & 165.50 & 154.53 & 184.45 & 250.24 & 220.40 & 305.77 & $1,280.89$ & 168.16 & 258.80 & $40 \%$ \\
\hline Belgium & 145.89 & 156.01 & 104.32 & 220.35 & 216.94 & 192.34 & $1,035.86$ & 135.41 & 209.88 & $99 \%$ \\
\hline Canada & 65.46 & 70.32 & 41.54 & 189.38 & 277.63 & 444.91 & $1,089.25$ & 59.11 & 303.98 & $55 \%$ \\
\hline Denmark & 216.37 & 237.87 & 199.13 & 232.48 & 257.24 & 281.18 & $1,424.26$ & 217.79 & 256.96 & $99 \%$ \\
\hline Finland & 100.25 & 140.56 & 128.05 & 89.40 & 98.57 & 94.60 & 651.44 & 122.95 & 94.19 & $47 \%$ \\
\hline France & $3,208.45$ & $3,822.31$ & $3,384.81$ & $4,145.92$ & $5,373.93$ & $6,118.58$ & $26,054.00$ & $3,471.85$ & $5,212.81$ & $10 \%$ \\
\hline Germany & $2,816.97$ & $3,005.56$ & $8,314.30$ & $9,806.01$ & $8,005.98$ & $8,137.28$ & $40,086.10$ & $4,712.28$ & $8,649.76$ & $39 \%$ \\
\hline Greece & 17.97 & 14.36 & 17.07 & 42.54 & 41.77 & 38.01 & 171.72 & 16.47 & 40.78 & $100 \%$ \\
\hline Iceland & 6.44 & 9.89 & 10.88 & 11.23 & 15.03 & 18.20 & 71.67 & 9.07 & 14.82 & $100 \%$ \\
\hline Ireland & 60.73 & 55.50 & 61.77 & 106.62 & 130.53 & 139.92 & 555.07 & 59.33 & 125.69 & $100 \%$ \\
\hline Italy & 254.64 & 206.23 & 545.23 & 630.53 & $1,017.29$ & 815.93 & $3,469.85$ & 335.37 & 821.25 & $79 \%$ \\
\hline Japan $^{\mathrm{a}}$ & $8,072.52$ & $8,211.65$ & $8,960.92$ & $10,885.52$ & $9,800.41$ & $11,024.86$ & $56,955.88$ & $8,415.03$ & $10,570.26$ & $14 \%$ \\
\hline Luxembourg & 38.32 & 47.59 & 52.45 & 71.15 & 59.88 & 75.93 & 345.31 & 46.12 & 68.99 & $67 \%$ \\
\hline Netherlands & 387.82 & 477.50 & 461.32 & 420.84 & 513.59 & 623.75 & $2,884.82$ & 442.22 & 519.39 & $100 \%$ \\
\hline New Zealand & 34.98 & 59.45 & 42.80 & 35.15 & 27.86 & 44.13 & 244.37 & 45.74 & 35.71 & $100 \%$ \\
\hline Norway & $1,179.50$ & 701.76 & 509.34 & 370.30 & 469.00 & 833.54 & $4,063.46$ & 796.87 & 557.62 & $77 \%$ \\
\hline Portugal & 37.86 & 24.79 & 28.76 & 47.51 & 47,00 & 45.78 & 231.69 & 30.47 & 46.76 & $100 \%$ \\
\hline Spain & 444.25 & 653.84 & 628.68 & 827.65 & 770.52 & 998.83 & $4,323.76$ & 575.59 & 865.66 & $38 \%$ \\
\hline Sweden & 379.76 & 332.80 & 414.14 & 517.62 & 580.95 & 692.06 & $2,917.34$ & 375.57 & 596.88 & $100 \%$ \\
\hline Switzerland & 216.36 & 224.68 & 237.05 & 274.40 & 287.21 & 261.88 & $1,501.58$ & 226.03 & 274.50 & $98 \%$ \\
\hline United Kingdom & $1,365.54$ & $1,547.95$ & $2,173.95$ & $1,778.88$ & $1,514.72$ & $1,902.68$ & $10,283.72$ & $1,695.81$ & $1,732.09$ & $93 \%$ \\
\hline United States $^{b}$ & $2,696.47$ & $2,770.93$ & $2,966.69$ & $3,270.20$ & $x^{b}$ & $x^{b}$ & $11,704.29^{b}$ & $2,811.36$ & $3,270.20^{b}$ & $43 \%^{b}$ \\
\hline $\begin{array}{l}\text { Total Annex II } \\
\text { countries }\end{array}$ & $22,148.40$ & $23,014.47$ & $29,651.39$ & $34,383.91$ & $29,889.15$ & $33,244.73$ & $172,332.04$ & $24,938.08$ & $32,505.93$ & \\
\hline
\end{tabular}

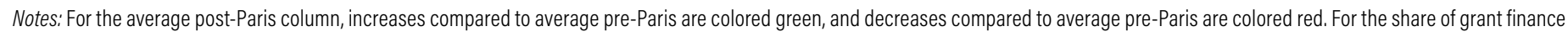
post-Paris column, coloring denotes grant share: 100 percent is shaded dark blue and 0 percent is light blue, with gradations by percentage in between.

a. Japan included coal-related finance in their climate finance reporting to the United Nations Framework Convention on Climate Change (UNFCCC).

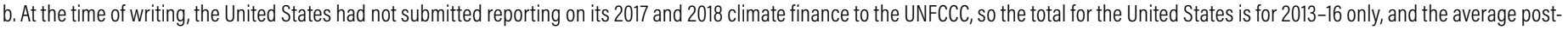
Paris and share of grant finance for the United States includes only its contributions in 2016. The U.S. grant share is for its 2016 finance only.

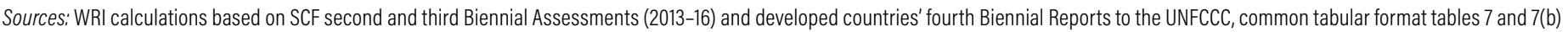

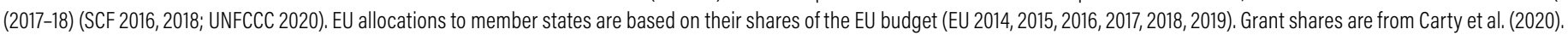


Table 23 | Total Attributed Climate Finance from Annex II Countries, All Channels: Bilateral and Multilateral Inflows and MDB Outflows (U.S. Dollars, Millions)

\begin{tabular}{|c|c|c|c|c|c|c|c|c|c|c|}
\hline & & & & & & & TOTAL & $\begin{array}{r}\text { ANNUAL } \\
\text { AVERAGE } \\
\text { PRE-PARIS } \\
\end{array}$ & $\begin{array}{r}\text { ANNUAL } \\
\text { AVERAGE } \\
\text { POST-PARIS } \\
\end{array}$ & $\begin{array}{r}\text { SHARE OF GRANT } \\
\text { FINANCE, BILAT- } \\
\text { ERAL AND MULTI- } \\
\text { LATERAL INFLOWS, } \\
\text { POST-PARIS } \\
\end{array}$ \\
\hline & 2013 & 2014 & 2015 & 2016 & 2017 & 2018 & 2013-18 & 2013-15 & 2016-18 & 2016-18 \\
\hline Australia & 542.62 & 435.40 & 466.32 & 498.15 & 756.18 & 720.54 & $3,419.20$ & 481.44 & 658.29 & $100 \%$ \\
\hline Austria & 351.49 & 405.59 & 384.34 & 469.28 & 540.63 & 628.69 & $2,780.02$ & 380.47 & 546.20 & $40 \%$ \\
\hline Belgium & 462.03 & 573.31 & 440.75 & 584.17 & 726.35 & 695.17 & $3,481.77$ & 492.03 & 668.56 & $99 \%$ \\
\hline Canada & 649.13 & 858.33 & 637.56 & 861.46 & $1,343.95$ & $1,485.26$ & $5,835.70$ & 715.01 & $1,230.23$ & $55 \%$ \\
\hline Denmark & 407.56 & 498.50 & 392.58 & 444.29 & 565.03 & 599.13 & $2,907.09$ & 432.88 & 536.15 & $99 \%$ \\
\hline Finland & 227.05 & 310.94 & 261.62 & 236.52 & 314.33 & 304.16 & $1,654.62$ & 266.53 & 285.00 & $47 \%$ \\
\hline France & $4,334.51$ & $5,308.75$ & 4,539.81 & $5,396.31$ & $7,200.75$ & $7,968.50$ & $34,748.63$ & $4,727,69$ & $6,855.18$ & $10 \%$ \\
\hline Germany & 4,096.03 & $4,730.66$ & $9,621.60$ & $11,219.23$ & $10,139.37$ & $10,313.49$ & $50,120.39$ & $6,149.43$ & $10,557.37$ & $39 \%$ \\
\hline Greece & 71.27 & 79.40 & 70.51 & 97.90 & 117.28 & 114.19 & 550.56 & 73.73 & 109.79 & $100 \%$ \\
\hline Iceland & 10.63 & 16.89 & 17.13 & 18.23 & 24.62 & 29.22 & 116.71 & 14.88 & 24.02 & $100 \%$ \\
\hline Ireland & 104.86 & 114.42 & 110.80 & 160.52 & 209.84 & 228.39 & 928.83 & 110.03 & 199.58 & $100 \%$ \\
\hline Italy & 1,199.95 & $1,415.67$ & $1,493.50$ & $1,651.74$ & $2,499.58$ & $2,323.95$ & $10,584.40$ & $1,369.71$ & $2,158.42$ & $79 \%$ \\
\hline Japan $^{\mathrm{a}}$ & $9,753.44$ & $10,474.29$ & $10,606.30$ & $12,729.49$ & $12,770,87$ & $14,114.47$ & $70,448.86$ & $10,278.01$ & $13,204.95$ & $14 \%$ \\
\hline Luxembourg & 59.17 & 75.61 & 74.63 & 97.99 & 102.54 & 119.03 & 528.96 & 69.80 & 106.52 & $67 \%$ \\
\hline Netherlands & 806.98 & $1,047.14$ & 886.95 & 894.73 & $1,211.60$ & $1,333.88$ & $6,181.28$ & 913.69 & $1,146.73$ & $100 \%$ \\
\hline New Zealand & 84.46 & 111.56 & 95.86 & 97.41 & 134.84 & 149.20 & 673.32 & 97.29 & 127.15 & $100 \%$ \\
\hline Norway & $1,318.42$ & 908.34 & 654.05 & 531.35 & 720.98 & $1,083.68$ & $5,216.81$ & 960.27 & 778.67 & $77 \%$ \\
\hline Portugal & 108.34 & 117,50 & 105.38 & 129.15 & 160.83 & 164.21 & 785.40 & 110.40 & 151.40 & $100 \%$ \\
\hline Spain & 928.51 & $1,281.25$ & $1,137,13$ & $1,405.18$ & $1,573.75$ & $1,829.05$ & $8,154.87$ & $1,115.63$ & $1,602.66$ & $38 \%$ \\
\hline Sweden & 680.76 & 759.71 & 721.12 & 849.01 & $1,085.56$ & 1,221.17 & $5,317.34$ & 720.53 & $1,051.91$ & $100 \%$ \\
\hline Switzerland & 426.37 & 537.55 & 447.89 & 566.46 & 711.72 & 668.27 & $3,358.26$ & 470.60 & 648.82 & $98 \%$ \\
\hline United Kingdom & $2,559.31$ & $3,198.56$ & $3,432.77$ & $3,116.65$ & $3,520.73$ & $4,017.58$ & $19,845.60$ & $3,063.55$ & $3,551.65$ & $93 \%$ \\
\hline United States $^{b}$ & 4,997.99 & $6,155.36$ & $5,825.36$ & $6,592.65$ & $4,916.92^{b}$ & $4,646.95^{b}$ & $33,135.23^{b}$ & $5,659.57$ & $7,565.64^{b}$ & $43 \%^{b}$ \\
\hline $\begin{array}{l}\text { Total Annex II } \\
\text { countries }\end{array}$ & $34,180.90$ & $39,414.73$ & $42,423.94$ & $48,647.87$ & $51,348.23$ & $54,758.18$ & $270,773.86$ & $38,673.19$ & $51,584.76$ & \\
\hline
\end{tabular}

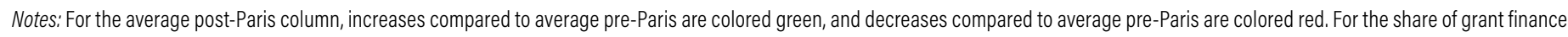
post-Paris column, coloring denotes grant share: 100 percent is shaded dark blue and 0 percent is light blue, with gradations by percentage in between.

a. Japan included coal-related finance in their climate finance reporting to the United Nations Framework Convention on Climate Change (UNFCCC).

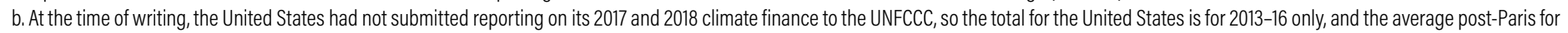
the United States includes only its bilateral and multilateral contributions in 2016 plus its average of MDB climate finance contributions for 2016-18. The U.S. grant share is for its 2016 finance only.

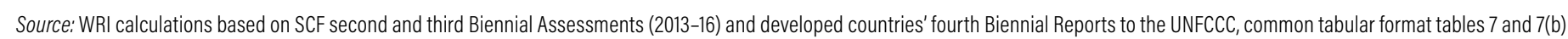

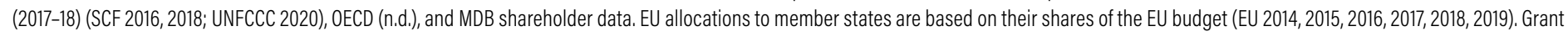
shares are from Carty et al. (2020). 
Figure 7 | Climate-Specific Finance Inflows by Country: Bilateral and Multilateral Inflows

12

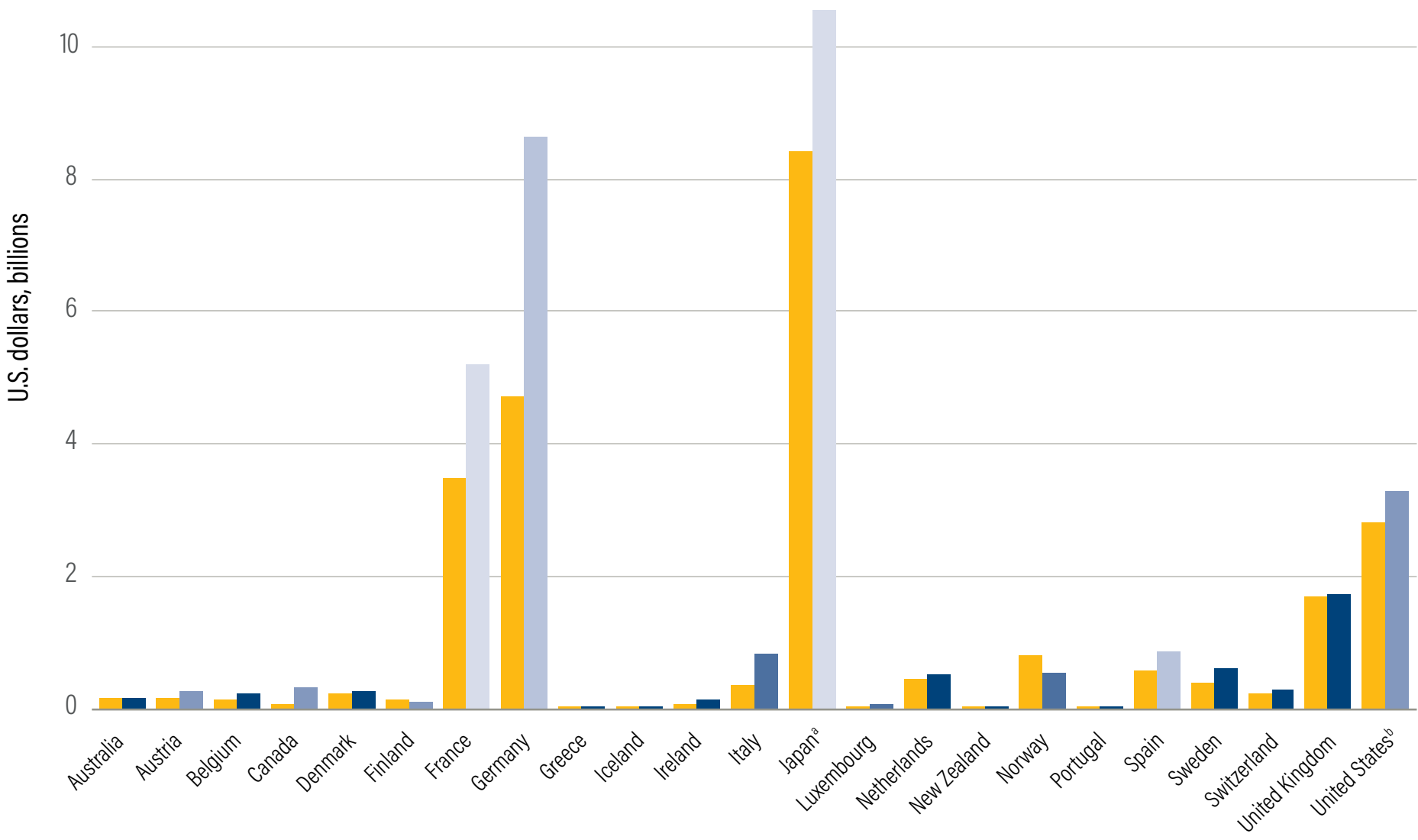

Annual average pre-Paris (2013-15)

Annual average post-Paris (2016-18)

Notes: Post-Paris bar shading denotes the share of grants in climate finance provided by quintile: darker is higher share, lighter is lower share.

a. Japan included coal-related finance in their climate finance reporting to the United Nations Framework Convention on Climate Change (UNFCCC).

b. At the time of writing, the United States had not submitted reporting on its 2017 and 2018 climate finance to the UNFCCC, so the average post-Paris for the United States includes only its bilateral and multilateral contributions in 2016. The U.S. grant share is for its 2016 finance only.

Sources: WRI calculations based on SCF second and third Biennial Assessments (2013-16) and developed countries' fourth Biennial Reports to the UNFCCC (2017-18) (SCF 2016, 2018; UNFCCC 2020). EU allocations to member states are based on their shares of the EU budget (EU 2014, 2015, 2016, 2017, 2018, 2019). Grant shares are from Carty et al. (2020). 
14

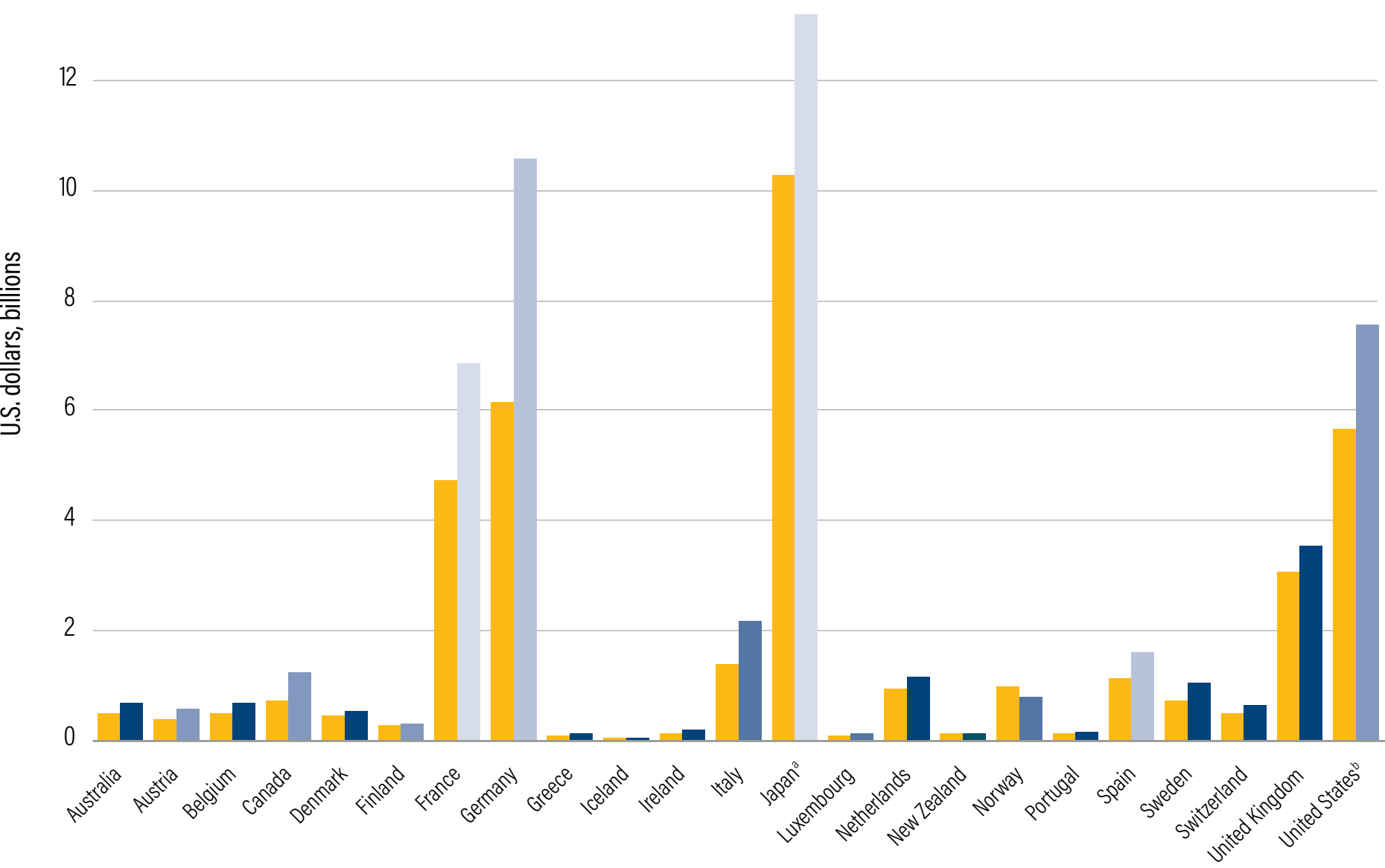

Annual average pre-Paris (2013-15) — Annual average post-Paris (2016-18)

Notes: Post-Paris bar shading denotes the share of grants in climate finance provided by quintile: darker is higher share, lighter is lower share. a. Japan includes coal-related finance in their climate finance reporting to the United Nations Framework Convention on Climate Change (UNFCCC).

b. At the time of writing, the United States had not submitted reporting on its 2017 and 2018 climate finance to the UNFCCC, so the average post-Paris for the United States includes only its bilateral and multilateral contributions in 2016 plus its average of MDB climate finance contributions for 2016-18. The U.S. grant share is for its 2016 finance only.

Sources: WRI calculations based on SCF second and third Biennial Assessments (2013-16) and developed countries' fourth Biennial Reports to the UNFCCC (2017-18) (SCF 2016, 2018; UNFCCC 2020), OECD (2021a), and MDB shareholder data. EU allocations to member states are based on their shares of the EU budget (EU 2014, 2015, 2016, 2017, 2018, 2019). Grant shares are from Carty et al. (2020). 
Table 24 | Climate Finance by Country and Channel, Annual Averages Post-Paris Agreement, 2016-18 (U.S. Dollars, Millions)

\begin{tabular}{|c|c|c|c|c|c|c|}
\hline & $\begin{array}{r}\text { ANNUAL AVERAGE } \\
\text { BILATERAL CLIMATE } \\
\text { FINANCE }\end{array}$ & $\begin{array}{r}\text { ANNUAL AVERAGE } \\
\text { MULTILATERAL } \\
\text { INSTITUTIONS }\end{array}$ & $\begin{array}{r}\text { ANNUAL AVERAGE } \\
\text { MULTILATERAL } \\
\text { DEVELOPMENT } \\
\text { BANKS }\end{array}$ & $\begin{array}{r}\text { ANNUAL AVERAGE } \\
\text { CLIMATE FINANCE } \\
\text { ALL CHANNELS } \\
(2016-18)\end{array}$ & $\begin{array}{r}\text { SHARE OF GRANT } \\
\text { FINANCE, BILATERAL }\end{array}$ & $\begin{array}{r}\text { SHARE OF GRANT } \\
\text { FINANCE, } \\
\text { MULTILATERAL } \\
\text { INSTITUTIONS }\end{array}$ \\
\hline Australia & 112.61 & 46.47 & 499.20 & 658.29 & $99 \%$ & $100 \%$ \\
\hline Austria & 239.07 & 19.73 & 287.40 & 546.20 & $25 \%$ & $77 \%$ \\
\hline Belgium & 174.60 & 35.28 & 458.68 & 668.56 & $98 \%$ & $100 \%$ \\
\hline Canada & 220.43 & 83.54 & 926.25 & $1,230.23$ & $38 \%$ & $100 \%$ \\
\hline Denmark & 216.68 & 40.28 & 279.19 & 536.15 & $98 \%$ & $100 \%$ \\
\hline Finland & 86.24 & 7.95 & 190.81 & 285.00 & $49 \%$ & $45 \%$ \\
\hline France & $4,884.42$ & 328.39 & $1,642.37$ & $6,855.18$ & $3 \%$ & $64 \%$ \\
\hline Germany & $8,255.74$ & 394.01 & $1,907.61$ & $10,557.37$ & $36 \%$ & $100 \%$ \\
\hline Greece & 40.53 & 0.25 & 69.01 & 109.79 & $100 \%$ & $100 \%$ \\
\hline Iceland & 13.99 & 0.83 & 9.20 & 24.02 & $100 \%$ & $100 \%$ \\
\hline Ireland & 118.35 & 7,33 & 73.89 & 199.58 & $100 \%$ & $99 \%$ \\
\hline Italy & 662.63 & 158.62 & 1,337.17 & $2,158.42$ & $63 \%$ & $100 \%$ \\
\hline Japan $^{\mathrm{a}}$ & $10,357.99$ & 212.28 & $2,634.68$ & $13,204.95$ & $12 \%$ & $100 \%$ \\
\hline Luxembourg & 50.78 & 18.21 & 37.53 & 106.52 & $100 \%$ & $51 \%$ \\
\hline Netherlands & 431.41 & 87.98 & 627.34 & $1,146.73$ & $100 \%$ & $100 \%$ \\
\hline New Zealand & 35.16 & 0.55 & 91.43 & 127.15 & $100 \%$ & $100 \%$ \\
\hline Norway & 531.02 & 26.60 & 221.05 & 778.67 & $75 \%$ & $100 \%$ \\
\hline Portugal & 46.76 & 0.00 & 104.63 & 151.40 & $100 \%$ & $\mathrm{~N} / \mathrm{A}$ \\
\hline Spain & 833.63 & 32.04 & 737.00 & $1,602.66$ & $26 \%$ & $74 \%$ \\
\hline Sweden & 482.87 & 114.01 & 455.04 & $1,051.91$ & $100 \%$ & $100 \%$ \\
\hline Switzerland & 215.05 & 59.45 & 374.32 & 648.82 & $98 \%$ & $100 \%$ \\
\hline United Kingdom & $1,448.74$ & 283.35 & $1,819.56$ & $3,551.65$ & $91 \%$ & $100 \%$ \\
\hline United States $^{b}$ & $1,897,60^{b}$ & $1,372.60^{\mathrm{b}}$ & $4,295.44$ & $7,565.64^{b}$ & $34 \%^{\mathrm{b}}$ & $56 \%^{\mathrm{b}}$ \\
\hline $\begin{array}{l}\text { Total Annex II } \\
\text { countries }\end{array}$ & $30,091.25$ & $2,414.69$ & $19,078.83$ & $51,584.76$ & & \\
\hline
\end{tabular}

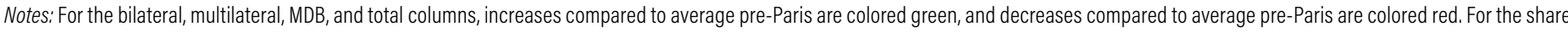

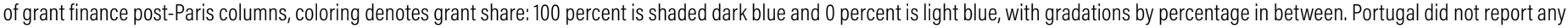
multilateral finance in the period 2016-18, so grant share is not included.

a. Japan included coal-related finance in their climate finance reporting to the United Nations Framework Convention on Climate Change (UNFCCC)

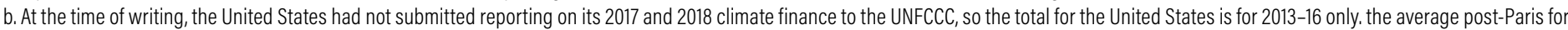

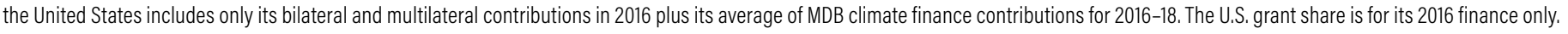

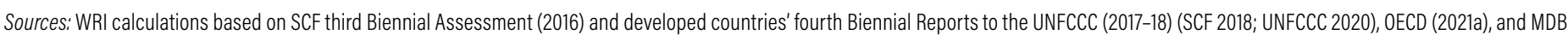
shareholder data. EU allocations to member states are based on their shares of the EU budget (EU 2017, 2018, 2019). Grant shares are from Carty et al. (2020). 
Figure 9 | Climate Finance by Country and Channel, Annual Averages Post-Paris Agreement (2016-18)

14

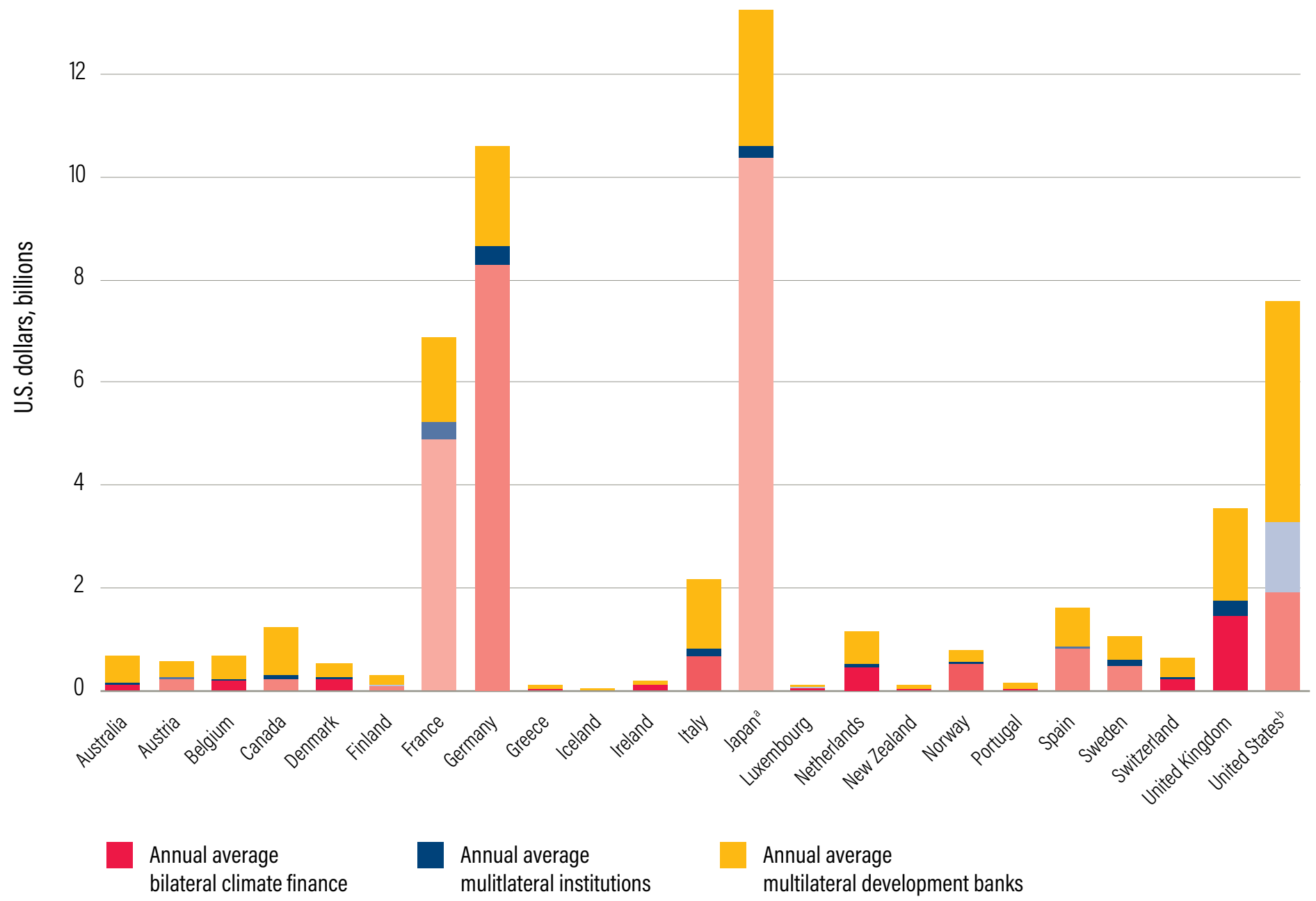

Notes: Bilateral and multilateral bar shading denotes the share of grants in climate finance provided by quintile: darker is higher share, lighter is lower share. a. Japan included coal-related finance in their climate finance reporting to the United Nations Framework Convention on Climate Change (UNFCCC).

b. At the time of writing, the United States had not submitted reporting on its 2017 and 2018 climate finance to the UNFCCC, so the average post-Paris for the United States includes only its bilateral and multilateral contributions in 2016 plus its average of MDB climate finance contributions for 2016-18. The U.S. grant share is for its 2016 finance only.

Sources: WRI calculations based on SCF third Biennial Assessment (2016) and developed countries' fourth Biennial Reports to the UNFCCC (2017-18) (SCF 2018; UNFCCC 2020), 0ECD (2021a), and MDB shareholder data. EU allocations to member states are based on their shares of the EU budget (EU 2017, 2018, 2019). Grant shares are from Carty et al. (2020). 


\subsection{Thematic Breakdown (Adaptation, Mitigation, Crosscutting, and Other)}

The Paris Agreement includes the goal that "the provision of scaled-up financial resources should aim to achieve a balance between adaptation and mitigation" (UNFCCC 2015, Article 9.4). Using the above data sources, we provided a breakdown of how climate finance was distributed between mitigation, adaptation, crosscutting, and "other" for the climate-specific inflows perspective (bilateral and multilateral climate-specific inflows).

\section{Sources}

Data from Table 7 in Annex II Parties' CTFs submitted as part of their second (2013 and 2014), third (2015 and 2016), and fourth (2017 and 2018) BRs (SCF 2016, 2018; UNFCCC 2020)

\section{Data gaps}

At the time of publication, the United States had not submitted its third or fourth BRs. For 2015-16, numbers reported in the third BA are used, which was based on preliminary data provided by the United States (SCF 2018). The United States did not provide a breakdown of its multilateral climate finance in the preliminary data provided for the third BA, so we were also unable to include a thematic breakdown of multilateral climate finance in 2015 and 2016. At the time of writing, there were no sources of U.S. data through the UNFCCC available for 2017 and 2018, so we did not include data on U.S. bilateral climate finance in those years.

\section{Adjustments}

Bilateral climate finance: Table 7 of the BR CTFs breaks down the bilateral climate finance in these categories: mitigation, adaptation, crosscutting, and other. These numbers were transcribed for each country. Crosscutting refers to finance that targets both mitigation and adaptation objectives. The "other" category has been used in a variety of ways by different countries. Some countries used this to report finance for reducing emissions from deforestation and forest degradation and the role of conservation, sustainable management of forests, and enhancement of forest carbon stocks in developing countries (REDD+), though for 2017 and 2018 almost all countries stopped using the category, likely in response to criticisms about the lack of transparency, instead allocating such finance to one of the other three categories.

Climate finance from the European Union is also allocated to its member states, using the budget share methodology outlined in the bilateral section above.

Multilateral climate funds: Table 7 of the BR CTFs breaks down the multilateral climate finance in the categories: mitigation, adaptation, crosscutting, and other. These numbers were transcribed for each country. Because these tables include climate finance to MDBs, and since MDB climate finance is addressed separately, any climate-specific general finance to MDBs reported in Table 7(a): Provision of Public Financial Support: Contribution through Multilateral Channels is then subtracted from the multilateral climate finance for each thematic area (mitigation, adaptation, crosscutting, and other).

- During the review process, representatives from Australia notified us that the thematic breakdowns for 2015, 2016, 2017, and 2018 in their CTFs were inaccurate and that their full BR had more updated figures, so we used those (totals for climate finance remain unchanged).

The thematic breakdown of climate finance inflows after these adjustments is shown in Table 25 and Figure 10. 


\begin{tabular}{|c|c|c|c|c|c|c|c|c|c|c|c|c|c|c|c|c|c|c|c|c|c|c|c|c|c|c|c|c|}
\hline \multirow[b]{2}{*}{ Thematic Area } & \multicolumn{4}{|c|}{2013} & \multicolumn{4}{|c|}{2014} & \multicolumn{4}{|c|}{2015} & \multicolumn{4}{|c|}{2016} & \multicolumn{4}{|c|}{2017} & \multicolumn{4}{|c|}{2018} & \multicolumn{4}{|c|}{ TOTAL 2016-18 } \\
\hline & M & A & C & 0 & M & A & C & 0 & M & A & C & 0 & M & A & C & 0 & M & A & C & 0 & M & A & C & 0 & M & A & C & 0 \\
\hline Australia & 21 & 27 & 51 & 0 & 0 & 46 & 54 & 0 & 7 & 44 & 49 & 0 & 5 & 29 & 66 & 0 & 15 & 52 & 34 & 0 & 13 & 65 & 22 & 0 & 10 & 46 & 44 & 0 \\
\hline Austria & 67 & 9 & 24 & 0 & 65 & 10 & 26 & 0 & 66 & 11 & 23 & 0 & 45 & 14 & 41 & 0 & 44 & 22 & 35 & 0 & 62 & 21 & 17 & 0 & 51 & 19 & 30 & 0 \\
\hline Belgium & 26 & 43 & 20 & 11 & 12 & 33 & 54 & 0 & 29 & 45 & 26 & 0 & 21 & 48 & 31 & 0 & 21 & 50 & 29 & 0 & 14 & 56 & 30 & 0 & 19 & 51 & 30 & 0 \\
\hline Canada & 5 & 84 & 11 & 0 & 4 & 90 & 6 & 0 & 4 & 87 & 9 & 0 & 5 & 24 & 71 & 0 & 8 & 30 & 62 & 0 & 38 & 14 & 47 & 0 & 22 & 21 & 57 & 0 \\
\hline Denmark & 25 & 11 & 65 & 0 & 26 & 10 & 64 & 0 & 23 & 13 & 61 & 3 & 25 & 26 & 48 & 0 & 29 & 29 & 41 & 0 & 38 & 27 & 35 & 0 & 31 & 28 & 41 & 0 \\
\hline Finland & 22 & 21 & 56 & 0 & 31 & 26 & 43 & 0 & 23 & 17 & 60 & 0 & 33 & 34 & 33 & 0 & 25 & 32 & 42 & 0 & 24 & 23 & 53 & 0 & 27 & 29 & 43 & 0 \\
\hline France & 74 & 18 & 8 & 0 & 79 & 11 & 11 & 0 & 57 & 25 & 18 & 0 & 65 & 15 & 19 & 0 & 68 & 19 & 13 & 0 & 49 & 23 & 28 & 0 & 60 & 20 & 20 & 0 \\
\hline Germany & 35 & 33 & 12 & 20 & 29 & 37 & 13 & 21 & 56 & 8 & 5 & 31 & 62 & 18 & 12 & 8 & 61 & 21 & 19 & 0 & 54 & 22 & 25 & 0 & 59 & 20 & 18 & 3 \\
\hline Greece & 30 & 33 & 37 & 0 & 29 & 28 & 44 & 0 & 34 & 36 & 30 & 0 & 32 & 44 & 24 & 0 & 25 & 43 & 32 & 0 & 21 & 37 & 42 & 0 & 26 & 42 & 32 & 0 \\
\hline Iceland & 1 & 11 & 87 & 0 & 6 & 18 & 77 & 0 & 19 & 57 & 24 & 0 & 34 & 53 & 13 & 0 & 23 & 51 & 26 & 0 & 21 & 56 & 23 & 0 & 25 & 53 & 22 & 0 \\
\hline Ireland & 13 & 58 & 29 & 0 & 9 & 59 & 31 & 1 & 16 & 56 & 28 & 0 & 16 & 61 & 21 & 2 & 12 & 46 & 42 & 0 & 10 & 24 & 67 & 0 & 12 & 42 & 45 & 1 \\
\hline Italy & 24 & 28 & 47 & 0 & 24 & 16 & 60 & 0 & 23 & 22 & 55 & 0 & 25 & 38 & 37 & 0 & 14 & 26 & 61 & 0 & 17 & 30 & 53 & 0 & 18 & 30 & 52 & 0 \\
\hline Japan ${ }^{\mathrm{a}}$ & 78 & 20 & 2 & 0 & 89 & 9 & 1 & 0 & 84 & 12 & 4 & 0 & 91 & 5 & 4 & 0 & 86 & 8 & 7 & 0 & 84 & 12 & 4 & 0 & 87 & 8 & 5 & 0 \\
\hline Luxembourg & 11 & 43 & 46 & 0 & 22 & 23 & 55 & 0 & 17 & 28 & 55 & 0 & 21 & 25 & 54 & 0 & 20 & 32 & 48 & 0 & 18 & 38 & 44 & 0 & 19 & 32 & 49 & 0 \\
\hline Netherlands & 29 & 16 & 55 & 0 & 26 & 40 & 34 & 0 & 15 & 40 & 44 & 0 & 13 & 48 & 39 & 0 & 15 & 45 & 39 & 0 & 17 & 42 & 41 & 0 & 15 & 44 & 40 & 0 \\
\hline New Zealand & 30 & 32 & 4 & 34 & 61 & 17 & 2 & 20 & 47 & 41 & 12 & 0 & 54 & 33 & 13 & 0 & 27 & 50 & 23 & 0 & 27 & 40 & 33 & 0 & 36 & 41 & 24 & 0 \\
\hline Norway & 5 & 0 & 94 & 0 & 2 & 0 & 98 & 0 & 53 & 7 & 10 & 30 & 63 & 7 & 9 & 21 & 81 & 12 & 8 & 0 & 86 & 6 & 7 & 1 & 79 & 8 & 8 & 5 \\
\hline Portugal & 68 & 16 & 16 & 0 & 59 & 19 & 22 & 0 & 39 & 28 & 32 & 0 & 34 & 43 & 23 & 0 & 27 & 44 & 29 & 0 & 21 & 39 & 39 & 0 & 28 & 42 & 31 & 0 \\
\hline Spain & 66 & 19 & 15 & 0 & 83 & 7 & 10 & 0 & 69 & 12 & 19 & 0 & 67 & 23 & 10 & 0 & 61 & 20 & 19 & 0 & 60 & 15 & 25 & 0 & 62 & 19 & 19 & 0 \\
\hline Sweden & 22 & 33 & 46 & 0 & 15 & 33 & 52 & 0 & 23 & 30 & 47 & 0 & 17 & 45 & 37 & 0 & 19 & 40 & 41 & 0 & 20 & 43 & 37 & 0 & 19 & 43 & 38 & 0 \\
\hline Switzerland & 33 & 57 & 10 & 0 & 39 & 51 & 10 & 0 & 32 & 41 & 26 & 0 & 37 & 38 & 26 & 0 & 30 & 45 & 25 & 0 & 35 & 52 & 13 & 0 & 34 & 45 & 21 & 0 \\
\hline United Kingdom & 22 & 21 & 44 & 13 & 10 & 19 & 58 & 13 & 20 & 17 & 28 & 35 & 29 & 32 & 19 & 20 & 38 & 42 & 20 & 0 & 38 & 39 & 23 & 0 & 35 & 38 & 21 & 7 \\
\hline United States $^{\mathrm{b}}$ & 83 & 15 & 3 & 0 & 82 & 15 & 3 & 0 & 83 & 11 & 6 & 0 & 70 & 23 & 7 & 0 & & $x$ & $x^{b}$ & & & $x^{\natural}$ & & & 70 & 23 & 7 & 0 \\
\hline
\end{tabular}

Total Annex II countries 
Figure 10 | Climate Finance Thematic Breakdown by Country, Post-Paris Agreement (2016-18)

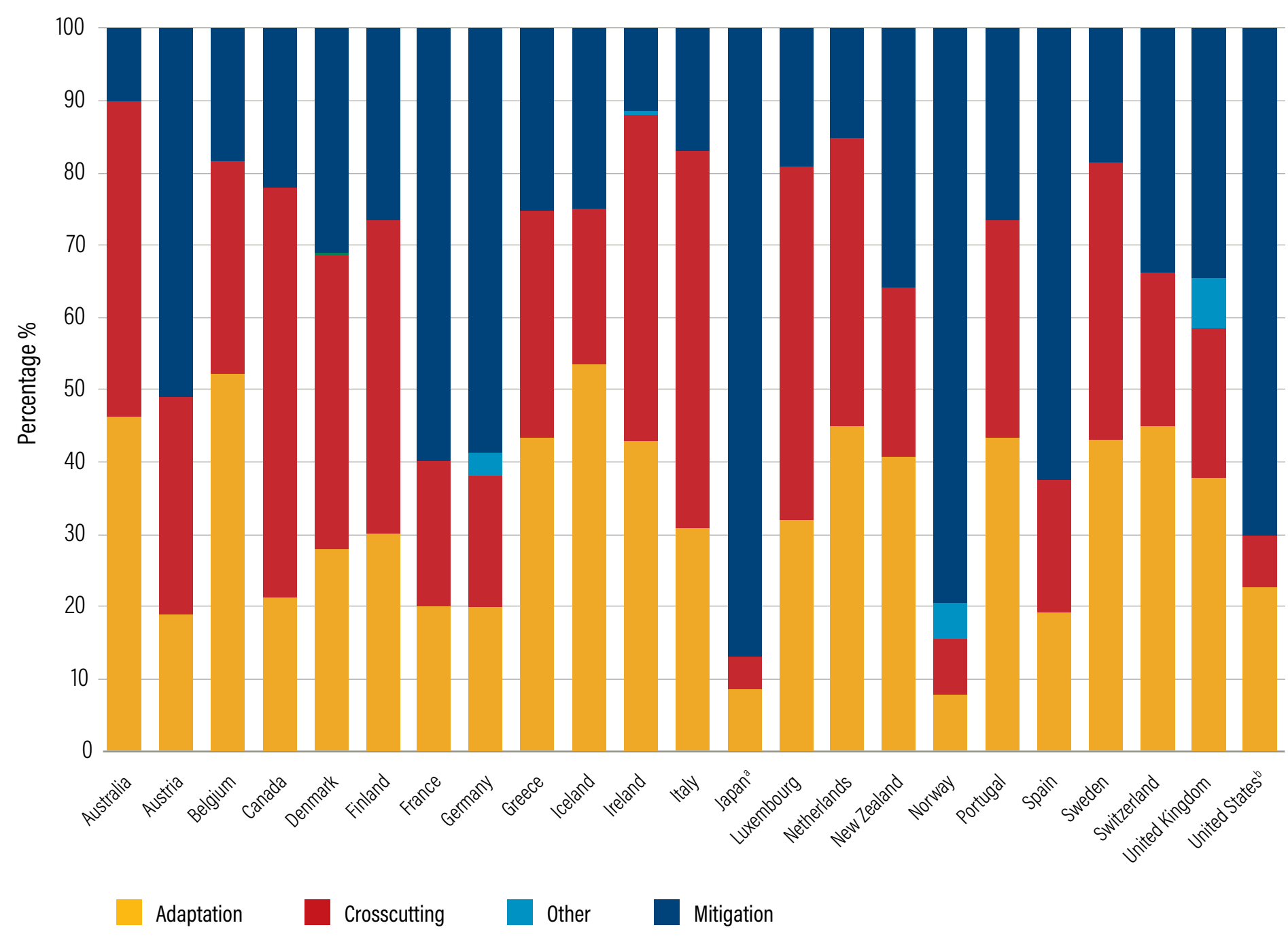

Notes: a. Japan included coal-related finance in their climate finance reporting to the United Nations Framework Convention on Climate Change (UNFCCC).

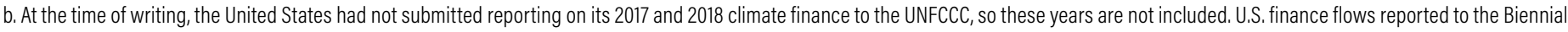
Assessment for 2016 did not provide a breakdown of multilateral finance, so this year covers only the U.S. bilateral breakdown.

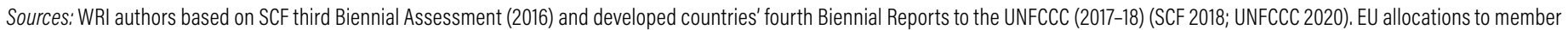
states are based their shares of the EU budget (EU 2017, 2018, 2019) 


\subsection{Percentage of GNI and Per Capita Share Analysis}

\section{Sources}

World Development Indicators from the World Bank, total population and GNI in current U.S. dollars (World Bank 2021)

- Oxfam Climate Finance Shadow Report for grant shares of bilateral finance, 2016-18 (Carty et al. 2020)

\section{Approach}

To compare each country's climate finance provision, we calculated total attributed climate finance provision as a percentage of their GNI and per capita. We divided climate finance for each country by its GNI (Table 27) and population (Table 29) in the corresponding year, and we also provided annual averages for the three years before (2013-15) and after (2016-18) the Paris Agreement was finalized at the end of 2015. Table 28 and Figure 11 show countries' climate finance as a share of their GNI, and Table 30 and Figure 12 show countries' climate finance per capita.

To provide a benchmark to assess country efforts, we calculated what an equal percentage share of GNI and per capita level of climate finance from each Annex II country would be necessary to achieve an overall climate finance goal. Because our analysis of climate finance attributable to each country only included public finance, but the $\$ 100$ billion goal can also include mobilized private finance, we created four stylized scenarios for the proportion of the goal that could be met with public finance. There is a general expectation that the share of public climate finance in fulfilling the $\$ 100$ billion commitment needs to be higher than the 2018 level of around $\$ 60$ billion. We set the low-end scenario at $\$ 70$ billion public finance, with $\$ 80$ billion and $\$ 90$ billion as the midrange, and a high-end scenario of all $\$ 100$ billion being met with public funding. Given that the $\$ 100$ billion commitment is a floor and not a ceiling for climate finance provision, the higher-range scenarios could be useful for exploring the level of public finance effort needed towards a total mobilization effort that well exceeds $\$ 100$ billion a year, especially considering calls for developed countries to do more in future years to make up for a likely shortfall towards the $\$ 100$ billion goal in 2020.5

To calculate the fixed GNI and per capita benchmarks, we followed three steps. First, we calculated the percentage of each country's GNI and population against the total GNI and population, respectively, for all Annex II countries (all averaged over the period 2016-18). Second, we multiplied this percentage by the total finance needed for each scenario $-\$ 70$ billion, $\$ 80$ billion, $\$ 90$ billion, and $\$ 100$ billiongiving the amount each country would need to provide. Third, the amount for each country, divided by its average GNI and population, respectively, over the period 2016-18, yields the same benchmark amount for every country (see Table 26). These benchmarks provide potential targets for countries. However, because there are significant per capita income differences between Annex II countries, an equal per capita climate finance contribution may not be an equitable way of sharing effort.

Table 26 | GNI and Per Capita Climate Finance Benchmarks for Annex II Countries under Different Public Finance Scenarios

\begin{tabular}{|c|c|c|}
\hline & $\begin{array}{l}\text { EQUAL GROSS NATIONAL INCOME SHARE } \\
\text { FROM ANNEX II COUNTRIES (\%) }\end{array}$ & $\begin{array}{l}\text { EQUAL PER CAPITA SHARE FROM ANNEX } \\
\text { II COUNTRIES (USS) }\end{array}$ \\
\hline$\$ 70$ billion public finance scenario & 0.15 & 74.51 \\
\hline$\$ 80$ billion public finance scenario & 0.18 & 85.16 \\
\hline$\$ 90$ billion public finance scenario & 0.20 & 95.80 \\
\hline$\$ 100$ billion public finance scenario & 0.22 & 106.45 \\
\hline
\end{tabular}

Source: WRI calculations based on World Bank (2021). 
Table 27 | GNI (Current U.S. Dollars, Millions)

\begin{tabular}{|c|c|c|c|c|c|c|c|}
\hline & & & & & & & $\begin{array}{r}\text { SHARE OF ANNEX II } \\
\text { COUNTRIES' TOTAL } \\
\text { POST-PARIS }\end{array}$ \\
\hline & 2013 & 2014 & 2015 & 2016 & 2017 & 2018 & 2016-18 \\
\hline Australia & $1,536,980$ & $1,429,083$ & $1,324,064$ & $1,180,244$ & $1,293,973$ & $1,389,127$ & $2.84 \%$ \\
\hline Austria & 431,229 & 442,579 & 378,058 & 395,198 & 414,599 & 454,258 & $0.93 \%$ \\
\hline Belgium & 534,493 & 545,897 & 468,690 & 480,572 & 509,690 & 546,514 & $1.13 \%$ \\
\hline Canada & $1,819,073$ & 1,774,391 & $1,532,290$ & $1,509,573$ & $1,630,712$ & $1,694,106$ & $3.55 \%$ \\
\hline Denmark & 354,464 & 365,834 & 311,964 & 320,813 & 336,416 & 364,913 & $0.75 \%$ \\
\hline Finland & 272,399 & 277,245 & 236,746 & 241,828 & 255,175 & 276,862 & $0.57 \%$ \\
\hline France & $2,874,043$ & $2,913,984$ & $2,490,863$ & $2,523,562$ & $2,654,458$ & $2,841,459$ & $5.90 \%$ \\
\hline Germany & $3,819,178$ & $3,961,736$ & $3,437,023$ & $3,552,144$ & $3,759,608$ & $4,060,013$ & $8.36 \%$ \\
\hline Greece & 239,573 & 238,635 & 196,862 & 195,230 & 203,984 & 216,983 & $0.45 \%$ \\
\hline Iceland & 15,288 & 16,897 & 16,544 & 19,827 & 23,966 & 24,926 & $0.05 \%$ \\
\hline Ireland & 201,257 & 218,187 & 224,070 & 245,118 & 266,555 & 300,179 & $0.60 \%$ \\
\hline Italy & $2,137,604$ & $2,159,322$ & $1,823,207$ & $1,881,183$ & $1,972,528$ & $2,108,430$ & $4.38 \%$ \\
\hline Japan & $5,328,796$ & $5,024,973$ & $4,558,091$ & $5,088,187$ & $5,040,348$ & $5,135,479$ & $11.22 \%$ \\
\hline Luxembourg & 41,235 & 43,911 & 37,619 & 38,640 & 41,383 & 45,78 & $0.09 \%$ \\
\hline Netherlands & 888,800 & 888,776 & 765,852 & 771,941 & 840,156 & 923,173 & $1.86 \%$ \\
\hline New Zealand & 183,260 & 192,720 & 171,232 & 181,819 & 194,716 & 196,958 & $0.42 \%$ \\
\hline Norway & 529,073 & 515,102 & 402,696 & 387,033 & 416,066 & 452,694 & $0.92 \%$ \\
\hline Portugal & 223,343 & 224,899 & 193,967 & 201,275 & 216,162 & 235,329 & $0.48 \%$ \\
\hline Spain & $1,345,710$ & $1,364,378$ & $1,194,851$ & $1,235,120$ & $1,312,248$ & $1,422,925$ & $2.92 \%$ \\
\hline Sweden & 597,818 & 592,528 & 507,679 & 518,717 & 549,762 & 565,750 & $1.20 \%$ \\
\hline Switzerland & 703,030 & 712,235 & 695,948 & 674,974 & 687,537 & 713,007 & $1.53 \%$ \\
\hline United Kingdom & $2,729,205$ & $3,001,243$ & $2,861,593$ & $2,629,567$ & $2,634,442$ & $2,816,806$ & $5.94 \%$ \\
\hline United States & $17,175,898$ & $18,057,489$ & $18,704,317$ & $19,045,164$ & $19,830,277$ & $20,837,347$ & $43.90 \%$ \\
\hline $\begin{array}{l}\text { Total Annex II } \\
\text { countries }\end{array}$ & $43,981,750$ & $44,962,044$ & $42,534,228$ & $43,317,730$ & $45,084,760$ & $47,622,417$ & $100.00 \%$ \\
\hline
\end{tabular}

Source: World Bank2021. 
Table 28 | Climate Finance as Share of GNI (Percent)

\begin{tabular}{|c|c|c|c|c|c|c|c|c|c|}
\hline & & & & & & & $\begin{array}{r}\text { ANNUAL } \\
\text { AVERAGE } \\
\text { PRE-PARIS }\end{array}$ & $\begin{array}{r}\text { ANNUAL } \\
\text { AVERAGE } \\
\text { POST-PARIS }\end{array}$ & $\begin{array}{r}\text { SHARE OF GRANT } \\
\text { FINANCE, BILATERAL } \\
\text { AND MULTILATERAL } \\
\text { INFLOWS, } \\
\text { POST-PARIS }\end{array}$ \\
\hline & 2013 & 2014 & 2015 & 2016 & 2017 & 2018 & 2013-15 & 2016-18 & 2016-18 \\
\hline Australia & 0.04 & 0.03 & 0.04 & 0.04 & 0.06 & 0.05 & 0.03 & 0.05 & $100 \%$ \\
\hline Austria & 0.08 & 0.09 & 0.10 & 0.12 & 0.13 & 0.14 & 0.09 & 0.13 & $40 \%$ \\
\hline Belgium & 0.09 & 0.11 & 0.09 & 0.12 & 0.14 & 0.13 & 0.10 & 0.13 & $99 \%$ \\
\hline Canada & 0.04 & 0.05 & 0.04 & 0.06 & 0.08 & 0.09 & 0.04 & 0.08 & $55 \%$ \\
\hline Denmark & 0.11 & 0.14 & 0.13 & 0.14 & 0.17 & 0.16 & 0.13 & 0.16 & $99 \%$ \\
\hline Finland & 0.08 & 0.11 & 0.11 & 0.10 & 0.12 & 0.11 & 0.10 & 0.11 & $47 \%$ \\
\hline France & 0.15 & 0.18 & 0.18 & 0.21 & 0.27 & 0.28 & 0.17 & 0.26 & $10 \%$ \\
\hline Germany & 0.11 & 0.12 & 0.28 & 0.32 & 0.27 & 0.25 & 0.17 & 0.28 & $39 \%$ \\
\hline Greece & 0.03 & 0.03 & 0.04 & 0.05 & 0.06 & 0.05 & 0.03 & 0.05 & $100 \%$ \\
\hline Iceland & 0.07 & 0.10 & 0.10 & 0.09 & 0.10 & 0.12 & 0.09 & 0.10 & $100 \%$ \\
\hline Ireland & 0.05 & 0.05 & 0.05 & 0.07 & 0.08 & 0.08 & 0.05 & 0.07 & $100 \%$ \\
\hline Italy & 0.06 & 0.07 & 0.08 & 0.09 & 0.13 & 0.11 & 0.07 & 0.11 & $79 \%$ \\
\hline Japan $^{\mathrm{a}}$ & 0.18 & 0.21 & 0.23 & 0.25 & 0.25 & 0.27 & 0.21 & 0.26 & $14 \%$ \\
\hline Luxembourg & 0.14 & 0.17 & 0.20 & 0.25 & 0.25 & 0.26 & 0.17 & 0.25 & $67 \%$ \\
\hline Netherlands & 0.09 & 0.12 & 0.12 & 0.12 & 0.14 & 0.14 & 0.11 & 0.13 & $100 \%$ \\
\hline New Zealand & 0.05 & 0.06 & 0.06 & 0.05 & 0.07 & 0.08 & 0.05 & 0.07 & $100 \%$ \\
\hline Norway & 0.25 & 0.18 & 0.16 & 0.14 & 0.17 & 0.24 & 0.20 & 0.18 & $77 \%$ \\
\hline Portugal & 0.05 & 0.05 & 0.05 & 0.06 & 0.07 & 0.07 & 0.05 & 0.07 & $100 \%$ \\
\hline Spain & 0.07 & 0.09 & 0.10 & 0.11 & 0.12 & 0.13 & 0.09 & 0.12 & $38 \%$ \\
\hline Sweden & 0.11 & 0.13 & 0.14 & 0.16 & 0.20 & 0.22 & 0.13 & 0.19 & $100 \%$ \\
\hline Switzerland & 0.06 & 0.08 & 0.06 & 0.08 & 0.10 & 0.09 & 0.07 & 0.09 & $98 \%$ \\
\hline United Kingdom & 0.09 & 0.11 & 0.12 & 0.12 & 0.13 & 0.14 & 0.11 & 0.13 & $93 \%$ \\
\hline United States $^{\mathrm{b}}$ & 0.03 & 0.03 & 0.03 & 0.03 & $0.02^{b}$ & $0.02^{b}$ & 0.03 & $0.03^{b}$ & $43 \%$ \\
\hline $\begin{array}{l}\text { Total Annex II } \\
\text { countries }\end{array}$ & 0.08 & 0.09 & 0.10 & 0.11 & 0.11 & 0.11 & 0.09 & 0.11 & \\
\hline
\end{tabular}

Notes: For the share of grant finance post-Paris columns, coloring denotes grant share: 100 percent is shaded dark blue and 0 percent is light blue, with gradations by percentage in between. a. Japan included coal-related finance in their climate finance reporting to the United Nations Framework Convention on Climate Change (UNFCCC).

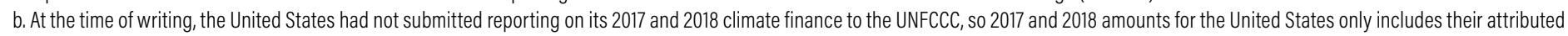
share of MDB climate finance outflows, and the average post-Paris for the United States includes only its bilateral and multilateral contributions in 2016 plus its average of MDB climate finance contributions for 2016-18. The U.S. grant share is for its 2016 finance only.

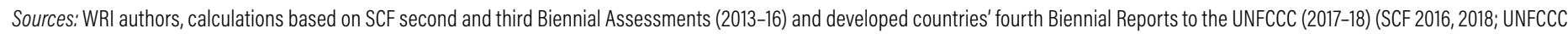

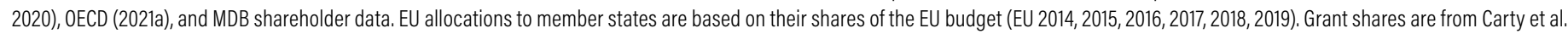
(2020). GNI data are from World Bank (2021). 
Figure 11 | Climate Finance as Share of GNI, Pre- and Post-Paris Agreement

0.30

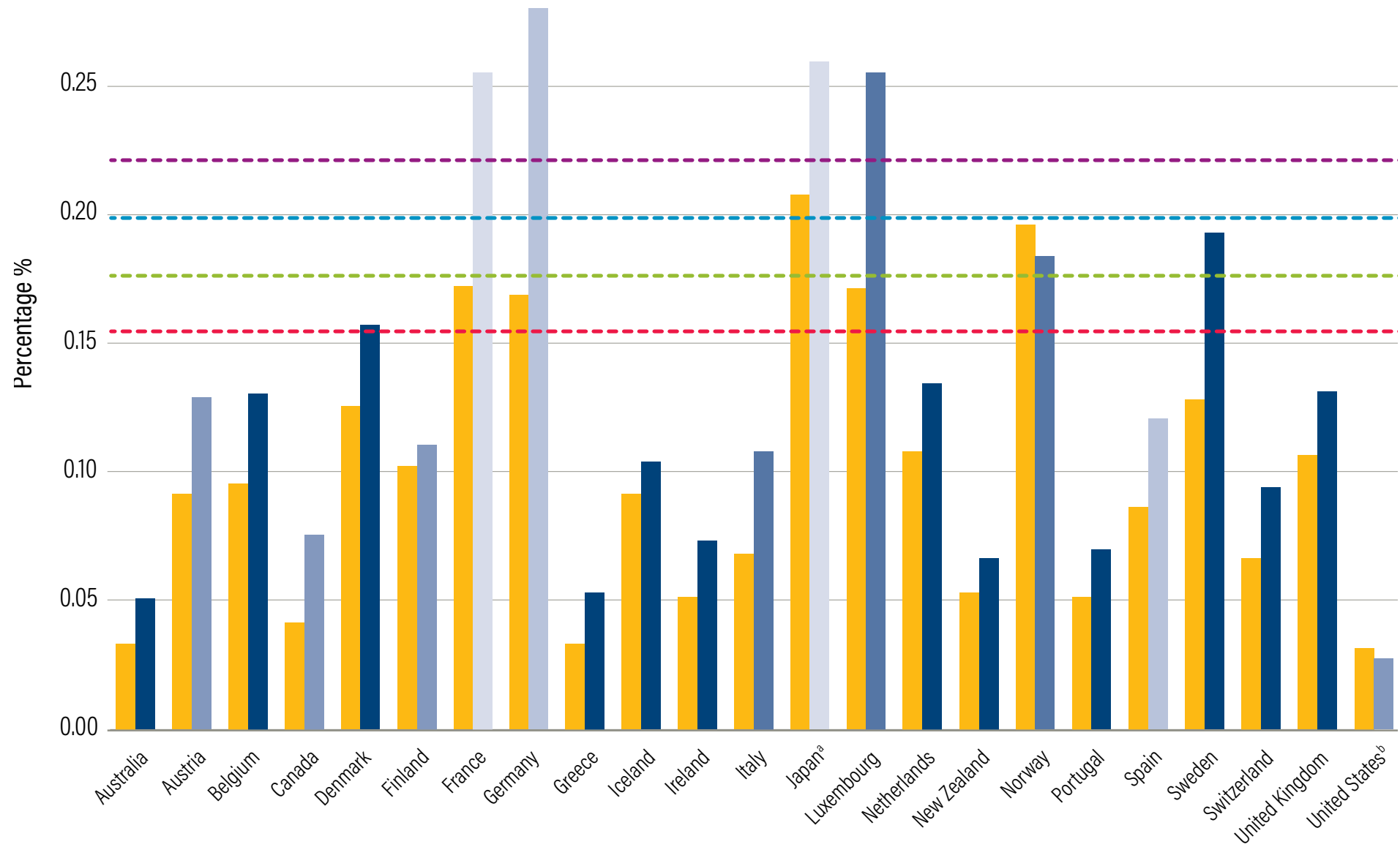

--- Equal GNI share for $\$ 70$ billion public finance

--- Equal GNI share for $\$ 80$ billion public finance

--- Equal GNI share for $\$ 90$ billion public finance

--- Equal GNI share for $\$ 100$ billion public finance

Notes: GNI = gross national income. Post-Paris bar shading denotes the share of grants in bilateral and multilateral climate finance provided by quintile: darker is higher share, lighter is lower share. a. Japan included coal-related finance in their climate finance reporting to the United Nations Framework Convention on Climate Change (UNFCCC).

b. At the time of writing, the United States had not submitted reporting on its 2017 and 2018 climate finance to the UNFCCC, so the average post-Paris for the United States includes only its bilateral and multilateral contributions in 2016 plus its average of MDB climate finance contributions for 2016-18. The U.S. grant share is for its 2016 finance only.

Source: WRI authors, based on SCF second and third Biennial Assessments (2013-16) and developed countries' fourth Biennial Reports to the UNFCCC (2017-18) (SCF 2016, 2018; UNFCCC 2020), 0ECD (2021a), and MDB shareholder data. EU allocations to member states are based on their shares of the EU budget (EU 2014, 2015, 2016, 2017, 2018, 2019). Grant shares are from Carty et al. (2020). GNI data are from World Bank (2021). 
Table 29 | Population

\begin{tabular}{|c|c|c|c|c|c|c|c|}
\hline & & & & & & & $\begin{array}{r}\text { SHARE OF ANNEX II } \\
\text { COUNTRIES' TOTAL } \\
\text { POST-PARIS }\end{array}$ \\
\hline & 2013 & 2014 & 2015 & 2016 & 2017 & 2018 & 2016-18 \\
\hline Australia & $23,128,129$ & $23,475,686$ & $23,815,995$ & $24,190,907$ & $24,601,860$ & $24,982,688$ & $2.62 \%$ \\
\hline Austria & $8,479,823$ & $8,546,356$ & $8,642,699$ & $8,736,668$ & $8,797,566$ & $8,840,521$ & $0.94 \%$ \\
\hline Belgium & $11,159,407$ & $11,209,057$ & $11,274,196$ & $11,331,422$ & $11,375,158$ & $11,427,054$ & $1.21 \%$ \\
\hline Canada & $35,082,954$ & $35,437,435$ & $35,702,908$ & $36,109,487$ & $36,543,321$ & $37,057,765$ & $3.89 \%$ \\
\hline Denmark & $5,614,932$ & $5,643,475$ & $5,683,483$ & $5,728,010$ & $5,764,980$ & $5,793,636$ & $0.61 \%$ \\
\hline Finland & $5,438,972$ & $5,461,512$ & $5,479,531$ & $5,495,303$ & $5,508,214$ & $5,515,525$ & $0.59 \%$ \\
\hline France & $65,998,687$ & $66,312,067$ & $66,548,272$ & $66,724,104$ & $66,864,379$ & $66,965,912$ & $7.12 \%$ \\
\hline Germany & $80,645,605$ & $80,982,500$ & $81,686,611$ & $82,348,669$ & $82,657,002$ & $82,905,782$ & $8.80 \%$ \\
\hline Greece & $10,965,211$ & $10,892,413$ & $10,820,883$ & $10,775,971$ & $10,754,679$ & $10,732,882$ & $1.14 \%$ \\
\hline Iceland & 323,764 & 327,386 & 330,815 & 335,439 & 343,400 & 352,721 & $0.04 \%$ \\
\hline Ireland & $4,623,816$ & $4,657,740$ & $4,701,957$ & $4,755,335$ & $4,807,388$ & $4,867,316$ & $0.51 \%$ \\
\hline Italy & $60,233,948$ & $60,789,140$ & $60,730,582$ & $60,627,498$ & $60,536,709$ & $60,421,760$ & $6.44 \%$ \\
\hline Japan & $127,445,000$ & $127,276,000$ & $127,141,000$ & $126,994,511$ & $126,785,797$ & $126,529,100$ & $13.49 \%$ \\
\hline Luxembourg & 543,360 & 556,319 & 569,604 & 582,014 & 596,336 & 607,950 & $0.06 \%$ \\
\hline Netherlands & $16,804,432$ & $16,865,008$ & $16,939,923$ & $17,030,314$ & $17,131,296$ & $17,231,624$ & $1.82 \%$ \\
\hline New Zealand & $4,442,100$ & $4,509,700$ & $4,595,700$ & $4,693,200$ & $4,793,900$ & $4,841,000$ & $0.51 \%$ \\
\hline Norway & $5,079,623$ & $5,137,232$ & $5,188,607$ & $5,234,519$ & $5,276,968$ & $5,311,916$ & $0.56 \%$ \\
\hline Portugal & $10,457,295$ & $10,401,062$ & $10,358,076$ & $10,325,452$ & $10,300,300$ & $10,283,822$ & $1.10 \%$ \\
\hline Spain & $46,620,045$ & $46,480,882$ & $46,444,832$ & $46,484,062$ & $46,593,236$ & $46,797,754$ & $4.96 \%$ \\
\hline Sweden & $9,600,379$ & $9,696,110$ & $9,799,186$ & $9,923,085$ & $10,057,698$ & $10,175,214$ & $1.07 \%$ \\
\hline Switzerland & $8,089,346$ & $8,188,649$ & $8,282,396$ & $8,373,338$ & $8,451,840$ & $8,514,329$ & $0.90 \%$ \\
\hline United Kingdom & $64,128,273$ & $64,602,298$ & $65,116,219$ & $65,611,593$ & $66,058,859$ & $66,460,344$ & $7.03 \%$ \\
\hline United States & $315,993,715$ & $318,301,008$ & $320,635,163$ & $322,941,311$ & $324,985,539$ & $326,687,501$ & $34.58 \%$ \\
\hline $\begin{array}{l}\text { Total Annex II } \\
\text { countries }\end{array}$ & $920,900,829$ & $925,751,049$ & $930,490,653$ & $935,354,228$ & $939,588,442$ & $943,306,134$ & $100.00 \%$ \\
\hline
\end{tabular}

Source: World Bank 2021. 
Table 30 | Climate Finance per Capita (U.S. Dollars)

\begin{tabular}{|c|c|c|c|c|c|c|c|c|c|}
\hline & & & & & & & $\begin{array}{r}\text { ANNUAL } \\
\text { AVERAGE } \\
\text { PRE-PARIS }\end{array}$ & $\begin{array}{r}\text { ANNUAL } \\
\text { AVERAGE } \\
\text { POST-PARIS }\end{array}$ & $\begin{array}{r}\text { SHARE OF GRANT } \\
\text { FINANCE, BILATERAL } \\
\text { AND MULTILATERAL } \\
\text { INFLOWS, } \\
\text { POST-PARIS }\end{array}$ \\
\hline & 2013 & 2014 & 2015 & 2016 & 2017 & 2018 & 2013-15 & 2016-18 & 2016-18 \\
\hline Australia & 23.46 & 18.55 & 19.58 & 20.59 & 30.74 & 28.84 & 20.53 & 26.72 & $100 \%$ \\
\hline Austria & 41.45 & 47.46 & 44.47 & 53.71 & 61.45 & 71.12 & 44.46 & 62.09 & $40 \%$ \\
\hline Belgium & 41.40 & 51.15 & 39.09 & 51.55 & 63.85 & 60.84 & 43.88 & 58.75 & $99 \%$ \\
\hline Canada & 18.50 & 24.22 & 17.86 & 23.86 & 36.78 & 40.08 & 20.19 & 33.57 & $55 \%$ \\
\hline Denmark & 72.59 & 88.33 & 69.07 & 77.56 & 98.01 & 103.41 & 76.66 & 93.00 & $99 \%$ \\
\hline Finland & 41.74 & 56.93 & 47.74 & 43.04 & 57.07 & 55.15 & 48.81 & 51.75 & $47 \%$ \\
\hline France & 65.68 & 80.06 & 68.22 & 80.87 & 107.69 & 118.99 & 71.32 & 102.52 & $10 \%$ \\
\hline Germany & 50.79 & 58.42 & 117.79 & 136.24 & 122.67 & 124.40 & 75.66 & 127.77 & $39 \%$ \\
\hline Greece & 6.50 & 7.29 & 6.52 & 9.08 & 10.91 & 10.64 & 6.77 & 10.21 & $100 \%$ \\
\hline Iceland & 32.83 & 51.59 & 51.77 & 54.35 & 71.69 & 82.83 & 45.40 & 69.62 & $100 \%$ \\
\hline Ireland & 22.68 & 24.57 & 23.56 & 33.76 & 43.65 & 46.92 & 23.60 & 41.44 & $100 \%$ \\
\hline Italy & 19.92 & 23.29 & 24.59 & 27.24 & 41.29 & 38.46 & 22.60 & 35.67 & $79 \%$ \\
\hline Japan $^{\mathrm{a}}$ & 76.53 & 82.30 & 83.42 & 100.24 & 100.73 & 111.55 & 80.75 & 104.17 & $14 \%$ \\
\hline Luxembourg & 108.89 & 135.91 & 131.02 & 168.36 & 171.95 & 195.78 & 125.28 & 178.70 & $67 \%$ \\
\hline Netherlands & 48.02 & 62.09 & 52.36 & 52.54 & 70.72 & 77,41 & 54.16 & 66.89 & $100 \%$ \\
\hline New Zealand & 19.01 & 24.74 & 20.86 & 20.76 & 28.13 & 30.82 & 21.54 & 26.57 & $100 \%$ \\
\hline Norway & 259.55 & 176.81 & 126.05 & 101.51 & 136.63 & 204.01 & 187.47 & 147.38 & $77 \%$ \\
\hline Portugal & 10.36 & 11.30 & 10.17 & 12.51 & 15.61 & 15.97 & 10.61 & 14.70 & $100 \%$ \\
\hline Spain & 19.92 & 27,57 & 24.48 & 30.23 & 33.78 & 39.08 & 23.99 & 34.36 & $38 \%$ \\
\hline Sweden & 70.91 & 78.35 & 73.59 & 85.56 & 107.93 & 120.01 & 74.28 & 104.50 & $100 \%$ \\
\hline Switzerland & 52.71 & 65.65 & 54.08 & 67.65 & 84.21 & 78.49 & 57.48 & 76.78 & $98 \%$ \\
\hline United Kingdom & 39.91 & 49.51 & 52.72 & 47.50 & 53.30 & 60.45 & 47.38 & 53.75 & $93 \%$ \\
\hline United States $^{b}$ & 15.82 & 19.34 & 18.17 & 20.41 & $15.13^{b}$ & $14.22^{b}$ & 17.77 & $16.59^{\mathrm{b}}$ & $43 \%$ \\
\hline $\begin{array}{l}\text { Total Annex II } \\
\text { countries }\end{array}$ & 37.12 & 42.58 & 45.59 & 52.01 & 54.65 & 58.05 & 41.76 & 54.90 & \\
\hline
\end{tabular}

Notes: For the share of grant finance post-Paris columns, coloring denotes grant share: 100 percent is shaded dark blue and 0 percent is light blue, with gradations by percentage in between. a. Japan included coal-related finance in their climate finance reporting to the United Nations Framework Convention on Climate Change (UNFCCC).

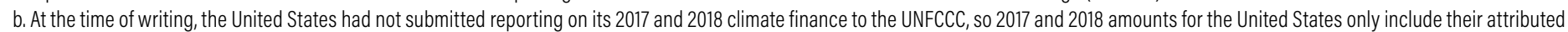
share of MDB climate finance outflows, and the average post-Paris for the United States includes only its bilateral and multilateral contributions in 2016 plus its average of MDB climate finance contributions for 2016-18. The U.S. grant share is for its 2016 finance only.

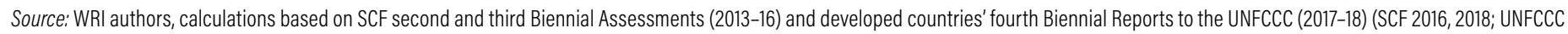

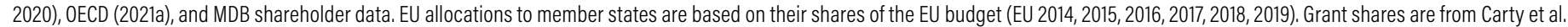
(2020). Population data are from World Bank (2021). 
200

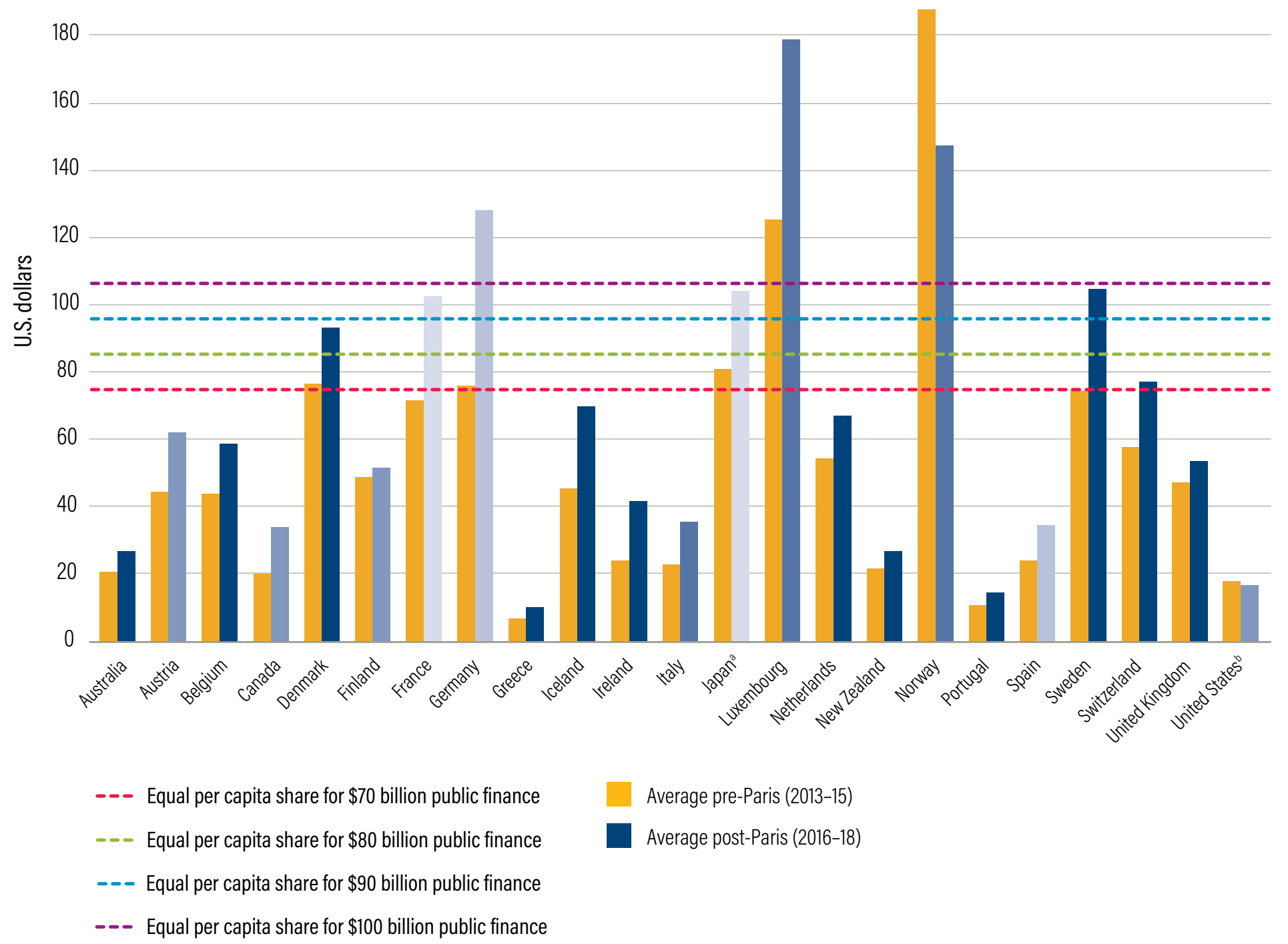

Notes: Post-Paris bar shading denotes the share of grants in bilateral and multilateral climate finance provided by quintile: darker is higher share, lighter is lower share. a. Japan included coal-related finance in their climate finance reporting to the United Nations Framework Convention on Climate Change (UNFCCC).

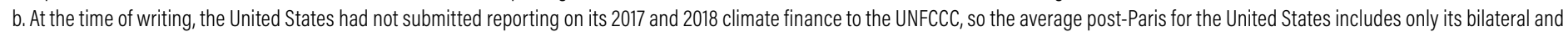
multilateral contributions in 2016 plus its average of MDB climate finance contributions for 2016-18.

Source: WRI authors, based on SCF second and third Biennial Assessments (2013-16) and developed countries' fourth Biennial Reports to the UNFCCC (2017-18) (SCF 2016, 2018; UNFCCC 2020),

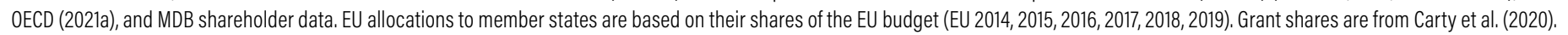
Population data are from World Bank (2021).are from World Bank (2021). 


\subsection{Effort-Sharing Analysis}

\section{Sources}

Oxfam Germany potential distribution key

(Kowalzig 2019)

ODI composite index shares (Colenbrander et al. 2021)

WRI indicative minimum threshold shares

(Waslander and Quijano Vallejos 2018; WRI 2018)

- Swiss Federal Institute of Technology Zurich

(Eidgenössische Technische Hochschule Zürich; ETH

Zurich), static and dynamic climate finance allocation mechanisms (Egli and Stünzi 2019)

- Oxfam Climate Finance Shadow Report for grant shares of bilateral finance, 2016-18 (Carty et al. 2020)

\section{Approach}

The $\$ 100$ billion is a collective commitment and there has been no agreement within the UNFCCC or among developed countries about how to share the effort towards meeting the goal. International institutions, such as the United Nations (for its general budget) and the European Union, employ gross national incomebased effort-sharing methodologies to determine budget contributions (EU 2019; UNGA 2018). The European Union also uses a GNI-based effort-sharing formula to determine how to allocate emissions reduction targets among its member states (EU 2009). Building on these examples, a variety of researchers have proposed approaches for how climate finance efforts could be equitably divided among developed countries based on objective data, such as greenhouse gas (GHG) emissions (a measure of responsibility for climate change), gross domestic product (GDP) or GNI (a measure of financial capacity/ability to pay), population (a measure of human capital), and ODA contributions (a measure of willingness to pay).

\section{Oxfam Germany's potential distribution} key for GCF replenishment: Oxfam Germany calculated a potential distribution approach for countries to pledge to the GCF replenishment; it did so by calculating each country's share of the Annex II countries' total nominal GDP (2018), cumulative carbon dioxide emissions (1990-2016), and ODA (2014-17) and then averaging the three so they are given equal weight (Kowalzig 2019). The published table in Kowalzig (2019) only includes selected Annex II countries; the author kindly supplied the breakdowns for all other Annex II countries.

ODI's composite index: ODI developed a composite index based on calculating each country's share of the Annex II countries' total GNI (2019), population (2019), and cumulative carbon dioxide emissions (1990-2018) and then averaging the three so they are given equal weight (Colenbrander et al. 2021). ODI only provided shares for the $\mathrm{G} 7$ plus Australia, so we replicated the calculations for all Annex II countries. ODI included Turkey in its calculations of Annex II country totals, but we excluded Turkey because it was removed from the list of Annex II Parties in 2002 pursuant to Decision 26/ CP.7 (UNFCCC 2001).

WRI's indicative minimum thresholds: To help inform the GCF's first replenishment process in 2019, WRI developed the indicative minimum threshold (IMT) formula for calculating the minimum share of effort each developed country could consider undertaking (Waslander and Quijano Vallejos 2018). The IMT shares are calculated based on each developed country's share of the GNI, averaged over 2011-16; the share of cumulative GHG emissions, based on averaged 1850-2016 and 1990-2016 cumulative data; and a scaling factor of GHG emissions per capita, depending on whether the contributor is above or below the average emissions of the 23 developed countries. The scaling factor is designed to incentivize countries to undertake domestic mitigation action by reducing the IMT for countries whose per capita emissions are below the group average and increasing the IMT for countries whose per capita emissions are above the group average. It also provides a level of fairness for countries that may have high aggregate emissions but larger populations. The full methodology for calculating the IMT can be found in Appendix A of Waslander and Quijano Vallejos (2018). We used the more up-to-date shares than appear in the publication, which underpin the online GCF Contributions Calculator 1.o (WRI 2018). 
ETH Zurich's static and dynamic climate finance allocation mechanisms: Other effort-sharing analyses rely solely on historic and contemporary data, but researchers at ETH Zurich developed an approach that also incorporates forward-looking data (Egli and Stünzi 2019). They began by calculating a static allocation mechanism based on a country's share of GDP (2017) and cumulative GHGs (1990-2014), similar to the approaches taken by other organizations. They then developed a dynamic allocation mechanism that extended the period of emissions covered out to 2030, using each countries' unconditional emissions reduction commitments included in their first round of nationally determined contributions (NDCs) under the Paris Agreement to project their cumulative emissions. They also extended wealth calculations out to 2030 by incorporating both GDP growth projections and subtracting the cost of projected climate damages to each country. The published paper applied the calculations for a broader group of countries than the scope of our study (all Annex I Parties plus Albania, Bosnia and Herzegovinia, Israel, Moldova, Montenegro, North Macedonia, and San Marino), and the authors kindly provided recalculated percentage shares only for the group of Annex II Parties.

Table 31 provides an overview of different proposed methodologies.

Table 32 shows the percentage share results. Although there are some variances, which can be significant for smaller countries, there is a significant degree of alignment for the major economies.

Table 31 | Comparison of Climate Finance Effort-Sharing Approach Methodologies

\begin{tabular}{|c|c|c|c|c|}
\hline & WEALTH & EMISSIONS & POPULATION & WILLINGNESS \\
\hline Oxfam distribution key & Share of GDP (2018) & $\begin{array}{l}\text { Share of carbon dioxide } \\
(1990-2016)\end{array}$ & $\mathrm{N} / \mathrm{A}$ & Share of ODA (2014-17) \\
\hline $\begin{array}{l}\text { ODI composite index } \\
\text { shares }\end{array}$ & Share of GNI (2019) & $\begin{array}{l}\text { Share of carbon dioxide } \\
(1990-2019)\end{array}$ & Share of population (2019) & N/A \\
\hline $\begin{array}{l}\text { WRI indicative minimum } \\
\text { shares }\end{array}$ & $\begin{array}{l}\text { Share of GNI (average of } \\
2011-16 \text { ) }\end{array}$ & $\begin{array}{l}\text { Share of GHGs (average of } \\
1850-2016 \text { and 1990-2016) }\end{array}$ & $\begin{array}{l}\text { Scaled up or down if per } \\
\text { capita GHGs are above or } \\
\text { below Annex II countries' } \\
\text { average (2011-16) }\end{array}$ & N/A \\
\hline $\begin{array}{l}\text { ETH Zurich static } \\
\text { allocation mechanism }\end{array}$ & Share of GDP (2017) & Share of GHGs (1990-2014) & $\mathrm{N} / \mathrm{A}$ & $\mathrm{N} / \mathrm{A}$ \\
\hline $\begin{array}{l}\text { ETH Zurich dynamic } \\
\text { allocation mechanism }\end{array}$ & $\begin{array}{l}\text { Share of GDP after } \\
\text { accounting for forecasted } \\
\text { growth and climate } \\
\text { damages (2030) }\end{array}$ & $\begin{array}{l}\text { Share of GHGs accounting for } \\
\text { unconditional emissions } \\
\text { reduction commitments in first } \\
\text { NDCs being met (1990-2030) }\end{array}$ & N/A & N/A \\
\hline
\end{tabular}

Notes: $\mathrm{GDP}$ = gross domestic product; $\mathrm{GHG}=$ greenhouse gas; $\mathrm{GNI}$ = gross national income; $\mathrm{NDC}=$ nationally determined contribution; $\mathrm{ODA}=$ official development assistance. Source: WRI authors, based on Colenbrander et al. (2021), Egli and Stünzi (2019), Kowalzig (2019), and Waslander and Quijano Vallejos (2018). 
Table 32 | Comparison of Climate Finance Effort-Sharing Approach Results (Percentage Shares)

\begin{tabular}{|c|c|c|c|c|c|}
\hline & $\begin{array}{l}\text { OXFAM POTENTIAL } \\
\text { DISTRIBUTION KEY }\end{array}$ & ODI COMPOSITE INDEX & $\begin{array}{r}\text { WRI INDICATIVE } \\
\text { MINIMUM THRESHOLD }\end{array}$ & $\begin{array}{r}\text { ETH ZURICH STATIC } \\
\text { ALLOCATION } \\
\text { MECHANISM }\end{array}$ & $\begin{array}{r}\text { ETH ZURICH DYNAMIC } \\
\text { ALLOCATION } \\
\text { MECHANISM }\end{array}$ \\
\hline Australia & 2.93 & 2.92 & 3.78 & 3.67 & 3.78 \\
\hline Austria & 0.86 & 0.83 & 0.72 & 0.79 & 0.74 \\
\hline Belgium & 1.26 & 1.13 & 1.16 & 1.08 & 1.03 \\
\hline Canada & 3.84 & 4.15 & 4.96 & 4.67 & 4.77 \\
\hline Denmark & 1.03 & 0.61 & 0.63 & 0.66 & 0.63 \\
\hline Finland & 0.67 & 0.55 & 0.76 & 0.57 & 0.54 \\
\hline France & 5.53 & 5.46 & 4.61 & 5.04 & 4.88 \\
\hline Germany & 10.56 & 8.29 & 8.65 & 8.07 & 7.62 \\
\hline Greece & 0.51 & 0.80 & 0.56 & 0.69 & 0.70 \\
\hline Iceland & 0.04 & 0.04 & 0.31 & 0.03 & 0.03 \\
\hline Ireland & 0.58 & 0.51 & 0.71 & 0.64 & 0.52 \\
\hline Italy & 3.86 & 4.80 & 3.44 & 4.28 & 3.95 \\
\hline$J^{J a p a n}{ }^{a}$ & 9.81 & 11.77 & 9.46 & 11.72 & 10.73 \\
\hline Luxembourg & 0.18 & 0.08 & 0.40 & 0.11 & 0.11 \\
\hline Netherlands & 2.43 & 1.75 & 1.91 & 1.80 & 1.66 \\
\hline New Zealand & 0.36 & 0.42 & 0.75 & 0.48 & 0.47 \\
\hline Norway & 1.46 & 0.60 & 0.63 & 0.72 & 0.73 \\
\hline Portugal & 0.42 & 0.69 & 0.42 & 0.54 & 0.49 \\
\hline Spain & 2.48 & 3.49 & 2.16 & 3.00 & 2.87 \\
\hline Sweden & 1.97 & 0.90 & 0.82 & 0.89 & 0.88 \\
\hline Switzerland & 1.47 & 0.94 & 0.86 & 0.92 & 0.89 \\
\hline United Kingdom & 7.72 & 5.85 & 6.45 & 5.58 & 5.30 \\
\hline United States & 40.05 & 43.41 & 45.88 & 44.04 & 46.67 \\
\hline Total Annex II countries & 100.00 & 100.00 & 100.00 & 100.00 & 100.00 \\
\hline
\end{tabular}

Notes: ETH Zurich = Eidgenössische Technische Hochschule Zürich (Swiss Federal Institute of Technology Zurich); ODI = Overseas Development Institute; WRI = World Resources Institute. Source: WRI authors, calculated based on approaches used by Colenbrander et al. (2021), Egli and Stünzi (2019), Kowalzig (2019), and WRI (2018). 
We compared our total attributed climate finance breakdowns against these shares. Although some analyses were developed to inform the GCF's replenishment, the shares from these calculations are based on universal data and can be applied more broadly to assessing public climate finance efforts, such as public finance contributions towards the $\$ 100$ billion goal.

Our analysis of climate finance attributable to each country only includes public finance, whereas the $\$ 100$ billion goal can also include mobilized private finance. As introduced in Section 3.3, we created four stylized scenarios for the proportion of the goal that could be met with public finance. There is a general expectation that the share of public climate finance in fulfilling the $\$ 100$ billion commitment needs to be higher than the 2018 level of around $\$ 60$ billion. We set the low-end scenario at $\$ 70$ billion public finance and a high-end scenario of all $\$ 100$ billion being met with public funding. Given that the $\$ 100$ billion commitment is a floor and not a ceiling for climate finance provision, the higher-range scenarios could be useful for exploring the level of public finance effort needed towards a total mobilization effort that well exceeds $\$ 100$ billion a year, especially in light of calls for developed countries to do more in future years to make up for a likely shortfall towards the $\$ 100$ billion goal in 2020. ${ }^{6}$ For each scenario, we multiplied the total amount of public finance by each country's percentage share under the different effort-sharing analyses to get their share in dollars (see Table 33). We plotted the low-end ( $\$ 70$ billion) and high-end scenarios ( $\$ 100$ billion public finance) as points alongside bars showing each country's total climate finance in 2018, which was the highest year for every country except the United States, which has not reported bilateral and multilateral inflows data for 2017 and 2018 to the UNFCCC; for the United States, we used its 2016 data instead (see Figure 13).

We then calculated for 2018 provision how much each country was exceeding or falling short of its idealized share under different effort sharing approaches in absolute terms for the low-end ( $\$ 70$ billion public finance) and high-end scenarios (\$10o billion public finance). Positive amounts denote countries that were already providing more than their indicative share under a particular effort sharing approach for the given scenario, negative amounts in red denote countries below their share under a particular effort sharing approach for the given scenario (see Table 34 and Figures 14 and 15). 
Table 33 | Climate Finance Compared to Different Effort-Sharing Approaches, 2018 (U.S. Dollars, Millions)

\begin{tabular}{|c|c|c|c|c|c|c|c|c|c|}
\hline & $\begin{array}{l}\text { TOTAL ATTRIBUTED } \\
\text { CLIMATE FINANCE, }\end{array}$ & \multicolumn{4}{|c|}{ LOW-END (\$70 BILLION PUBLIC FINANCE) SCENARIO } & \multicolumn{4}{|c|}{ HIGH-END (\$100 BILLION PUBLIC FINANCE) SCENARIO } \\
\hline & 2018 & $\begin{array}{l}\text { Oxfam } \\
\text { shares }\end{array}$ & ODI shares & WRI shares & $\begin{array}{r}\text { ETH Zurich } \\
\text { dynamic } \\
\text { shares }\end{array}$ & $\begin{array}{l}\text { Oxfam } \\
\text { shares }\end{array}$ & ODI shares & $\begin{array}{r}\text { WRI } \\
\text { shares }\end{array}$ & $\begin{array}{r}\text { ETH Zurich } \\
\text { Dynamic } \\
\text { Shares }\end{array}$ \\
\hline Australia & 720.54 & $2,048.51$ & $2,044.56$ & $2,644.69$ & $2,646.25$ & $2,926.44$ & $2,920.79$ & $3,778.13$ & $3,780.35$ \\
\hline Austria & 628.69 & 599.64 & 579.32 & 504.12 & 514.70 & 856.63 & 827,60 & 720.17 & 735.28 \\
\hline Belgium & 695.17 & 881.29 & 789.82 & 812.93 & 719.51 & $1,258.99$ & $1,128.32$ & $1,161.33$ & $1,027.87$ \\
\hline Canada & $1,485.26$ & $2,685.62$ & $2,907,88$ & $3,469.69$ & $3,340.19$ & $3,836.59$ & $4,154,11$ & $4,956.69$ & $4,771.70$ \\
\hline Denmark & 599.13 & 722.84 & 426.78 & 442.88 & 442.81 & $1,032.63$ & 609.69 & 632.68 & 632.59 \\
\hline Finland & 304.16 & 469.15 & 387.07 & 532.68 & 379.58 & 670.22 & 552.96 & 760.98 & 542.26 \\
\hline France & $7,968.50$ & $3,873.94$ & $3,819.20$ & $3,226.97$ & $3,415.02$ & $5,534,19$ & $5,455.99$ & $4,609.96$ & $4,878.60$ \\
\hline Germany & $10,313.49$ & 7,391.91 & $5,805.87$ & $6,053.50$ & $5,334.88$ & $10,559.88$ & $8,294.10$ & $8,647.85$ & $7,621.26$ \\
\hline Greece & 114.19 & 354.43 & 557.64 & 391.82 & 492.68 & 506.33 & 796.63 & 559.74 & 703.83 \\
\hline Iceland & 29.22 & 27.84 & 27.26 & 213.55 & 20.65 & 39.77 & 38.94 & 305.08 & 29.50 \\
\hline Ireland & 228.39 & 405.33 & 355.87 & 493.72 & 361.09 & 579.05 & 508.38 & 705.32 & 515.84 \\
\hline Italy & $2,323.95$ & $2,698.98$ & $3,357,88$ & $2,408.20$ & $2,767.98$ & $3,855.69$ & $4,796.97$ & $3,440.29$ & $3,954.26$ \\
\hline Japan $^{\mathrm{a}}$ & $14,114,47$ & $6,866.39$ & $8,241.15$ & $6,619.12$ & $7,512.03$ & $9,809.13$ & $11,773.07$ & $9,455.88$ & $10,731.47$ \\
\hline Luxembourg & 119.03 & 123.64 & 58.94 & 283.22 & 78.66 & 176.63 & 84.20 & 404.60 & 112.37 \\
\hline Netherlands & $1,333.88$ & $1,702.94$ & $1,227.67$ & $1,333.70$ & $1,163.39$ & $2,432.77$ & $1,753.81$ & $1,905.29$ & $1,661.99$ \\
\hline New Zealand & 149.20 & 251.40 & 291.23 & 521.74 & 327.88 & 359.15 & 416.04 & 745.34 & 468.40 \\
\hline Norway & $1,083.68$ & $1,024.83$ & 423.08 & 439.95 & 509.33 & $1,464.04$ & 604.40 & 628.50 & 727.61 \\
\hline Portugal & 164.21 & 297.06 & 484.44 & 292.90 & 344.45 & 424.38 & 692.05 & 418.44 & 492.07 \\
\hline Spain & $1,829.05$ & $1,735.22$ & $2,442.99$ & $1,511.26$ & $2,007.05$ & $2,478.89$ & $3,489.99$ & $2,158.95$ & $2,867.22$ \\
\hline Sweden & 1,221.17 & $1,376.19$ & 628.33 & 572.34 & 617.72 & $1,965.98$ & 897.62 & 817.62 & 882.45 \\
\hline Switzerland & 668.27 & $1,026.36$ & 658.14 & 601.68 & 626.47 & $1,466.22$ & 940.20 & 859.55 & 894.95 \\
\hline United Kingdom & $4,017.58$ & $5,403.50$ & $4,094.48$ & $4,516.51$ & $3,711.70$ & $7,719.29$ & $5,849.26$ & $6,452.16$ & $5,302.44$ \\
\hline United States ${ }^{b}$ & $6,592.65^{b}$ & $28,032.98$ & $30,390.41$ & $32,112.83$ & $32,665.99$ & $40,047,11$ & $43,414.87$ & $45,875.47$ & $46,665.71$ \\
\hline $\begin{array}{l}\text { Total Annex II } \\
\text { countries }\end{array}$ & $54,758.18$ & $70,000.00$ & $70,000.00$ & $70,000.00$ & $70,000.00$ & $100,000.00$ & $100,000.00$ & $100,000.00$ & $100,000.00$ \\
\hline
\end{tabular}

Notes: ETH Zurich = Eidgenössische Technische Hochschule Zürich (Swiss Federal Institute of Technology Zurich); ODI = Overseas Development Institute; WRI = World Resources Institute. a. Japan included coal-related finance in their climate finance reporting to the United Nations Framework Convention on Climate Change (UNFCCC).

b. At the time of writing, the United States had not submitted reporting on its 2017 and 2018 climate finance to the UNFCCC, so we used its 2016 climate finance instead.

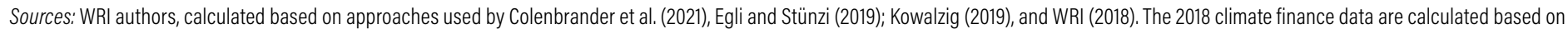

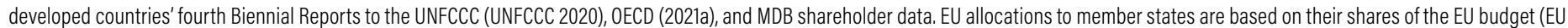
2019). Grant shares are from Carty et al. (2020). 
Table 34 | Climate Finance above/below Different Effort-Sharing Approaches, 2018 (U.S. Dollars, Millions)

\begin{tabular}{|c|c|c|c|c|c|c|c|c|c|}
\hline & $\begin{array}{l}\text { TOTAL ATTRIBUTED } \\
\text { CLIMATE FINANCE, }\end{array}$ & LOW-END & (S70 BILLION P & IC FINANCE) & SCENARIO & HIGH-END & I\$100 BILLION P & BLIC FINANCE & SCENARIO \\
\hline & 2018 & $\begin{array}{l}\text { Oxfam } \\
\text { shares }\end{array}$ & ODI shares & $\begin{array}{r}\text { WRI } \\
\text { shares }\end{array}$ & $\begin{array}{r}\text { ETH Zurich } \\
\text { dynamic } \\
\text { shares }\end{array}$ & $\begin{array}{l}\text { Oxfam } \\
\text { shares }\end{array}$ & ODI shares & $\begin{array}{r}\text { WRI } \\
\text { shares }\end{array}$ & $\begin{array}{l}\text { ETH Zurich } \\
\text { Dynamic } \\
\text { Shares }\end{array}$ \\
\hline Australia & 720.54 & $-1,327,97$ & $-1,324,02$ & $-1,924,15$ & $-1,925.71$ & $-2,205.90$ & $-2,200.26$ & $-3,057,59$ & $-3,059.81$ \\
\hline Austria & 628.69 & 29.06 & 49.38 & 124.57 & 114.00 & -227.93 & -198.90 & -91.48 & -106.59 \\
\hline Belgium & 695.17 & -186.12 & -94.65 & -117.76 & -24.34 & -563.81 & -433.14 & -466.16 & -332.70 \\
\hline Canada & $1,485.26$ & $-1,200.35$ & $-1,422.61$ & $-1,984.42$ & $-1,854.93$ & $-2,351.33$ & $-2,668.85$ & $-3,471.43$ & $-3,286.44$ \\
\hline Denmark & 599.13 & -123.71 & 172.35 & 156.25 & 156.32 & -433.50 & -10.56 & -33.55 & -33.46 \\
\hline Finland & 304.16 & -164.99 & -82.91 & -228.52 & -75.42 & -366.05 & -248.80 & -456.81 & -238.09 \\
\hline France & $7,968.50$ & $4,094.56$ & $4,149.30$ & $4,741.53$ & $4,553.48$ & $2,434.30$ & $2,512.50$ & $3,358.54$ & $3,089.90$ \\
\hline Germany & $10,313.49$ & $2,921.58$ & $4,507.62$ & $4,260.00$ & $4,978.61$ & -246.38 & $2,019.40$ & $1,665.64$ & $2,692.24$ \\
\hline Greece & 114.19 & -240.24 & -443.45 & -277.63 & -378.49 & -392.14 & -682.44 & -445.55 & -589.64 \\
\hline Iceland & 29.22 & 1.38 & 1.96 & -184.34 & 8.57 & -10.56 & -9.73 & -275.86 & -0.28 \\
\hline Ireland & 228.39 & -176.95 & -127.48 & -265.33 & -132.70 & -350.66 & -280.00 & -476.93 & -287.45 \\
\hline Italy & $2,323.95$ & -375.03 & $-1,033.93$ & -84.25 & -444.03 & $-1,531.74$ & $-2,473.02$ & $-1,116.34$ & $-1,630.31$ \\
\hline$J^{\prime a p a n}{ }^{a}$ & $14,114.47$ & $7,248.08$ & $5,873.32$ & $7,495.35$ & $6,602.45$ & $4,305.34$ & $2,341.40$ & $4,658.59$ & $3,383.01$ \\
\hline Luxembourg & 119.03 & -4.61 & 60.08 & -164.19 & 40.37 & -57.60 & 34.82 & -285.57 & 6.66 \\
\hline Netherlands & $1,333.88$ & -369.06 & 106.21 & 0.18 & 170.48 & $-1,098.89$ & -419.93 & -571.41 & -328.11 \\
\hline New Zealand & 149.20 & -102.21 & -142.04 & -372.54 & -178.69 & -209.95 & -266.85 & -596.14 & -319.21 \\
\hline Norway & $1,083.68$ & 58.85 & 660.60 & 643.73 & 574.36 & -380.36 & 479.29 & 455.18 & 356.07 \\
\hline Portugal & 164.21 & -132.85 & -320.23 & -128.69 & -180.24 & -260.17 & -527.84 & -254.22 & -327.86 \\
\hline Spain & $1,829.05$ & 93.83 & -613.95 & 317.79 & -178.00 & -649.84 & $-1,660.94$ & -329.90 & $-1,038.17$ \\
\hline Sweden & 1,221.17 & -155.01 & 592.84 & 648.84 & 603.46 & -744.81 & 323.56 & 403.55 & 338.72 \\
\hline Switzerland & 668.27 & -358.09 & 10.13 & 66.59 & 41.80 & -797.96 & -271.93 & -191.28 & -226.68 \\
\hline United Kingdom & $4,017.58$ & $-1,385.92$ & -76.91 & -498.93 & 305.87 & $-3,701,71$ & $-1,831.69$ & $-2,434,58$ & $-1,284.86$ \\
\hline United States $^{\mathrm{b}}$ & $6,592.65^{b}$ & $-21,440.33$ & $-23,797,76$ & $-25,520.19$ & $-26,073.35$ & $-33,454,46$ & $-36,822.22$ & $-39,282,83$ & $-40,073.06$ \\
\hline $\begin{array}{l}\text { Total Annex II } \\
\text { countries }\end{array}$ & $54,758.18$ & & & & & & & & \\
\hline
\end{tabular}

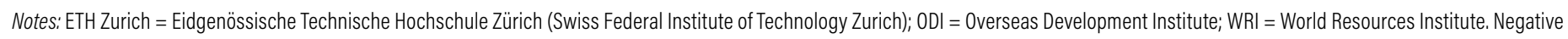
amounts are in red.

a. Japan included coal-related finance in their climate finance reporting to the United Nations Framework Convention on Climate Change (UNFCCC)

b. At the time of writing, the United States had not submitted reporting on its 2017 and 2018 climate finance to the UNFCCC, so we used its 2016 climate finance instead.

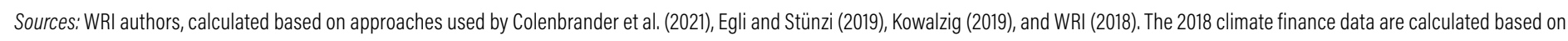

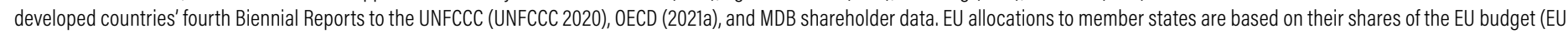
2019). Grant shares are from Carty et al. (2020). 
Figure 13 | Climate Finance Compared to Different Effort-Sharing Approaches, 2018

$$
50
$$

45

40

35

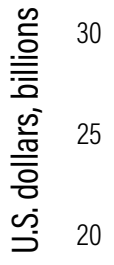

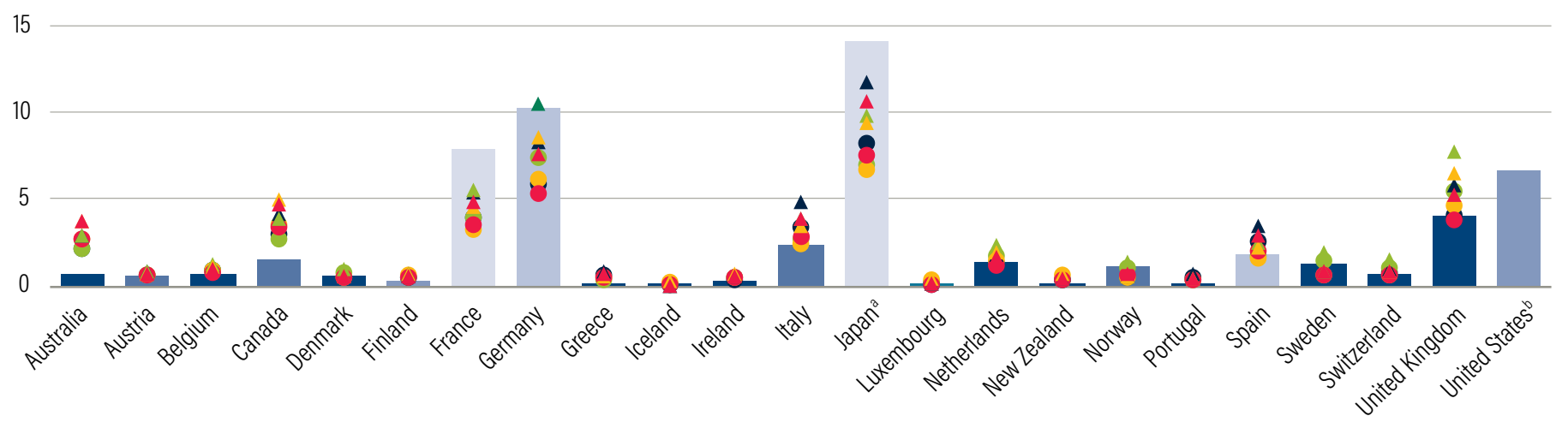

2018 climate finance

- ODI shares of $\$ 70$ billion

Oxfam shares of $\$ 70$ billion

WRI shares of $\$ 70$ billion

ETH Zurich dynamic shares of $\$ 70$ billion

$\Delta$ ODI shares of $\$ 100$ billion

$\triangle 0 x f a m$ shares of $\$ 100$ billion

$\triangle$ WRI shares of $\$ 100$ billion

$\Delta$ ETH Zurich dynamic shares of $\$ 100$ billion

Notes: ETH Zurich = Eidgenössische Technische Hochschule Zürich (Swiss Federal Institute of Technology Zurich); ODI = Overseas Development Institute; WRI = World Resources Institute. Bar shading denotes the share of grants in bilateral and multilateral climate finance provided in 2016-18 by quintile: darker is higher share, lighter is lower share. a. Japan included coal-related finance in their climate finance reporting to the United Nations Framework Convention on Climate Change (UNFCCC). b. At the time of writing, the United States had not submitted reporting on its 2017 and 2018 climate finance to the UNFCCC, so the graph uses U.S. climate finance in 2016 , the latest year for which reporting is available.

Sources: WRI authors, calculated based on approaches used by Colenbrander et al. (2021), Egli and Stünzi (2019), Kowalzig (2019), and WRI (2018). The 2018 climate finance data are calculated based on developed countries' fourth Biennial Reports to the UNFCCC (UNFCCC 2020), OECD (2021a), and MDB shareholder data. EU allocations to member states are based on their shares of the EU budget (EU 2019). Grant shares are from Carty et al. (2020).Population data are from World Bank (2021).are from World Bank (2021). 
10

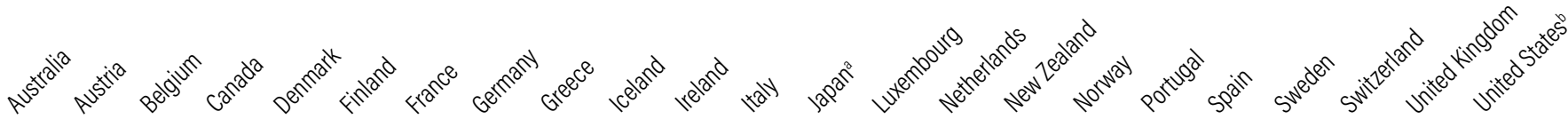

5

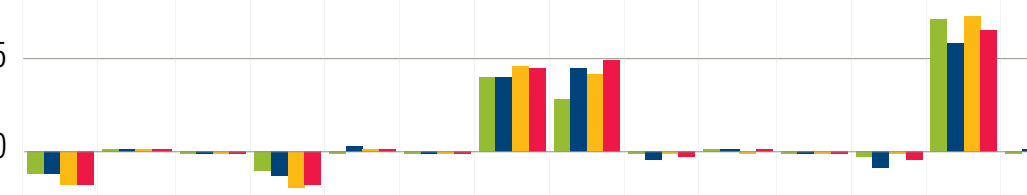

$-5$

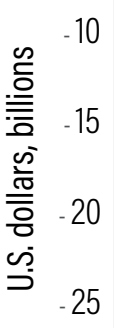

$-30$

$-35$

$-40$

$-45$
Oxfam
ODI
WRI
ETH Zurich

Notes: ETH Zurich = Eidgenössische Technische Hochschule Zürich (Swiss Federal Institute of Technology Zurich); ODI = Overseas Development Institute; WRI = World Resources Institute. a. Japan included coal-related finance in their climate finance reporting to the United Nations Framework Convention on Climate Change (UNFCCC).

b. At the time of writing, the United States had not submitted reporting on its 2017 and 2018 climate finance to the UNFCCC, so the graph uses U.S. climate finance in 2016, the latest year for which reporting is available.

Sources: WRI authors, calculated based on approaches used by Colenbrander et al. (2021), Egli and Stünzi (2019), Kowalzig (2019), and WRI (2018. The 2018 climate finance data are calculated based on developed countries' fourth Biennial Reports to the UNFCCC (UNFCCC 2020), OECD (2021a), and MDB shareholder data. EU allocations to member states are based on their shares of the EU budget (EU 2019). 
Figure 15 | Climate Finance above/below Different Effort-Sharing Approaches for the High-End (\$100 Billion) Public Finance Scenario, 2018

10

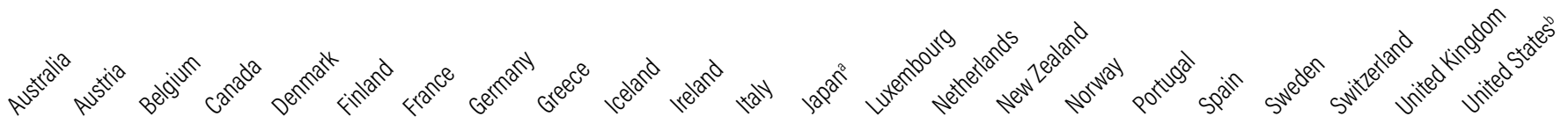

5

0

$-5$
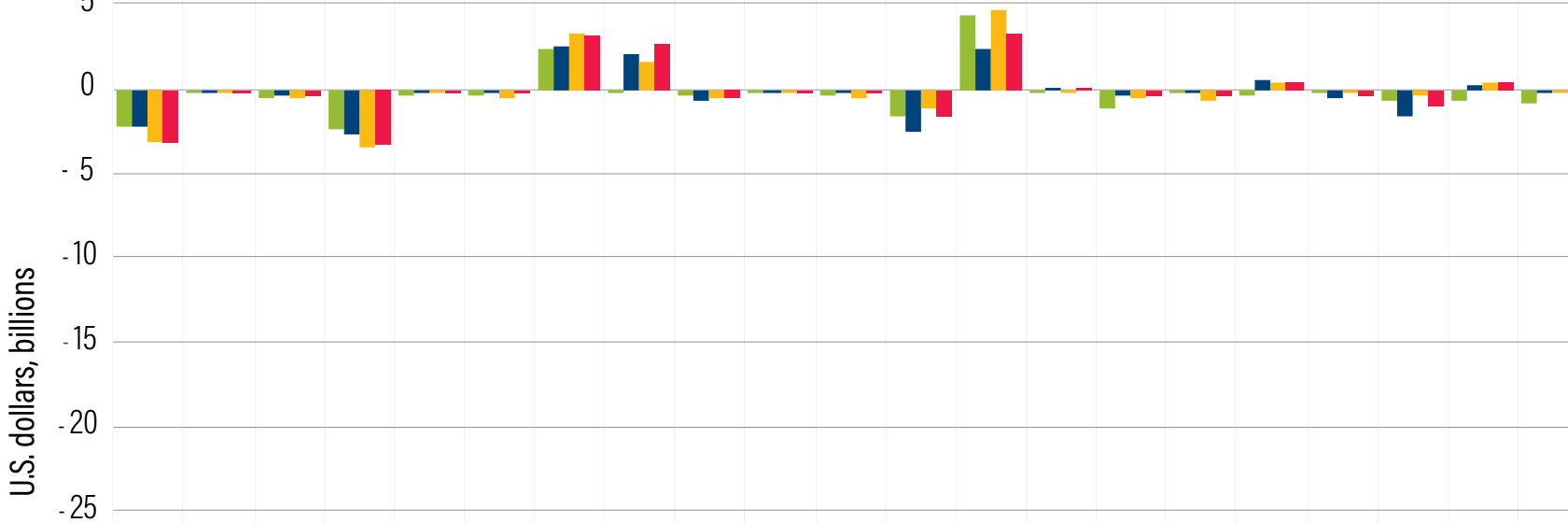

$-30$

$-35$

.40

.45
Oxfam
ODI
WRI
ETH Zurich

Notes: ETH Zurich = Eidgenössische Technische Hochschule Zürich (Swiss Federal Institute of Technology Zurich); ODI = Overseas Development Institute; WRI = World Resources Institute. a. Japan included coal-related finance in their climate finance reporting to the United Nations Framework Convention on Climate Change (UNFCCC).

b. At the time of writing, the United States had not submitted reporting on its 2017 and 2018 climate finance to the UNFCCC, so the graph uses U.S. climate finance in 2016 , the latest year for which reporting is available.

Sources: Calculated based on approaches used by Colenbrander et al. (2021), Egli and Stünzi (2019), Kowalzig (2019), and WRI (2018). The 2018 climate finance data are calculated based on developed countries' fourth Biennial Reports to the UNFCCC (UNFCCC 2020), OECD (2021a), and MDB shareholder data. EU allocations to member states are based on their shares of the EU budget (EU 2019). 


\section{CONCLUSIONS}

Our methodology sought to fill a gap left by other analyses of climate finance towards the $\$ 100$ billion a year commitment, which focus on aggregate total climate finance provided by all developed countries. We calculated country-by-country breakdowns for their reported climate finance provision each year between 2013 and 2018, including bilateral finance, multilateral climate-specific finance inflows, share of MDB climate finance outflows, and share of climate finance from the European Union, if applicable.

We presented two perspectives: climate-specific inflows, which aim to capture each country's direct climatespecific contributions from their national budgets, and total attributed climate finance, which includes shares of MDB climate finance outflows. This aims to capture how much climate finance each country could ultimately claim credit for towards the $\$ 100$ billion goal. Using the climatespecific inflows perspective, we were able to compare each country's share of mitigation and adaptation finance through bilateral and multilateral climate-specific channels. Using the total attributed climate finance, it was possible to compare efforts in nominal terms as well as across a variety of other metrics that attempted to standardize comparison: on a per capita basis, as a percentage of GNI, and progress against different effortsharing approaches based on objective data.

The data sets we have created can be used to develop comparisons of country efforts towards meeting the $\$ 100$ billion goal. We plan to use this data in infographics and potentially interactive tools, and we encourage others to explore the data and use it to make the case for greater quantity and quality of climate finance. Our methodology can also be applied to future climate finance reporting when it becomes available to cover additional years.
It is important to note that this data is based on country self-reporting, with significant differences in what and how countries report climate finance (see Section 2.1, Methodological Challenges). Comparisons between countries therefore need to consider how the differences in reporting approaches and the quality of finance provided affect the totals climate finance reported. Whereas some countries are more stringent about which projects to report as climate relevant and about how to quantify the climate-specific proportions of projects, others take a more generous approach. Countries also vary in the composition of their climate finance, with some countries providing more of their finance as grants while others provide a majority as loans and other nongrant instruments. Countries using a substantial share of nongrant instruments would see their reported climate finance amounts drop significantly if grantequivalent accounting is used-in some cases, by half. A grant-equivalent accounting approach could provide a more comparable assessment of governmental budgetary efforts, and this could be explored in future research. We also encountered a number of reporting errors and a lack of disaggregated reporting data, which made verification of discrepancies challenging.

This highlights the importance of all countries and multilateral institutions continuing to take steps to improve the quality, transparency, and consistency of their climate finance reporting. In particular, more granular and detailed reporting would allow data to be more easily verified and adjusted to present a more consistent assessment of country contributions. It would also help build trust between contributors and recipients. 


\section{APPENDIX A: A COMPARISON OF UNFCCC AND OECD COUNTRY CATEGORIES}

Table A1 | Status of Countries in the UNFCCC and OECD ODA Categories
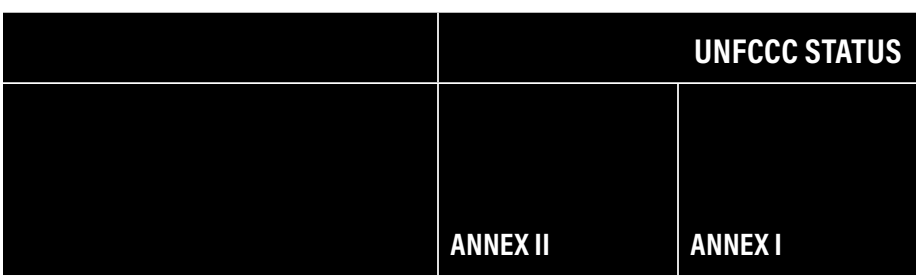

Afghanistan

Albania

Algeria

Andorra

Angola

Antigua and Barbuda

Argentina

Armenia

Australia

Austria

Azerbaijan

Bahamas

Bahrain

Bangladesh

Barbados

Belarus

Belgium

Belize

Benin

Bhutan

Bolivia (Plurinational State of)

Bosnia and Herzegovina

\section{Botswana}

Brazil

Brunei Darussalam

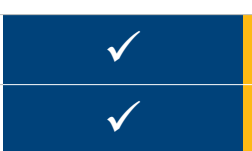

\begin{tabular}{|l}
2 \\
\hline \\
\hline
\end{tabular}

No

NON-ANNEXI
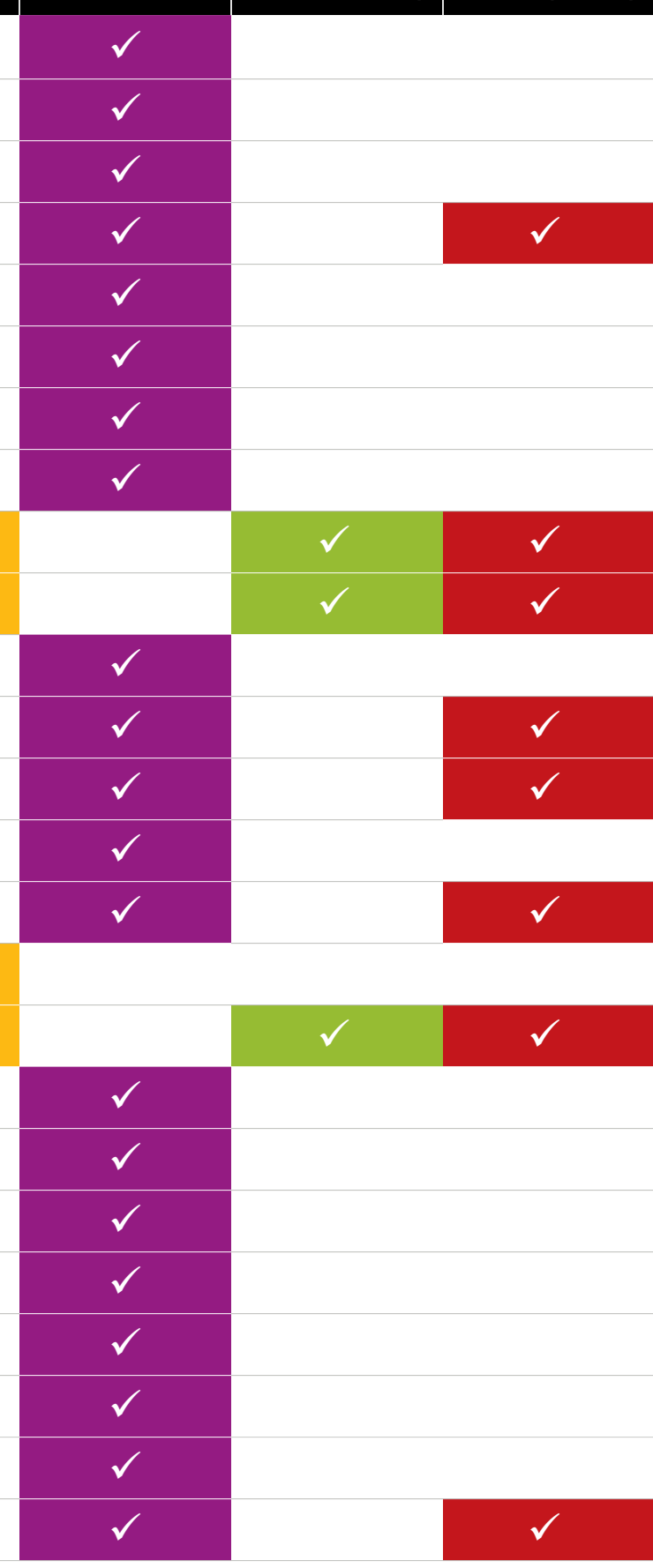

\section{OECD ODA STATUS}

\begin{tabular}{r|r|r} 
DEVELOPMENT & & \\
ASSISTANCE & & \\
COMMITTEE & & \\
MEMBER (ODA & ODA INELIGIBLE & ODA ELIGIBLE \\
CONTRIBUTORS) & $(2013-18)$ & $(2013-18)$ \\
\hline
\end{tabular}
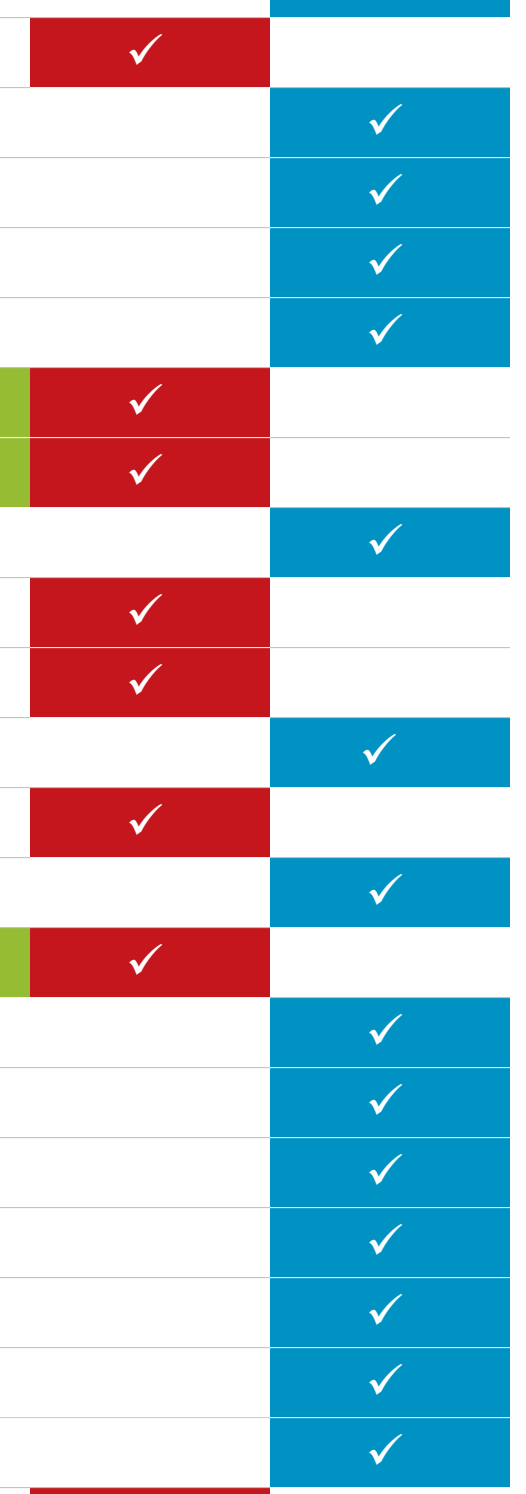
Table A1 | Status of Countries in the UNFCCC and OECD ODA Categories (cont.)

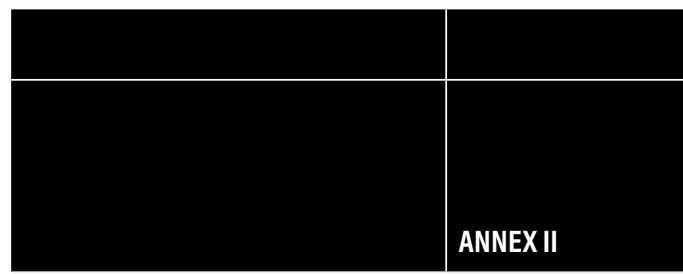

UNFCCC STATUS

Bulgaria

Burkina Faso

Burundi

Cabo Verde

Cambodia

Cameroon

Canada

Central African Republic

Chad

Chile

China

Colombia

Comoros

Congo

Cook Islands

Costa Rica

Côte d'Ivoire

Croatia

Cuba

Cyprus

Czechia

Democratic People's

Republic of Korea

Democratic Republic of the Congo

Denmark

Djibouti

Dominica
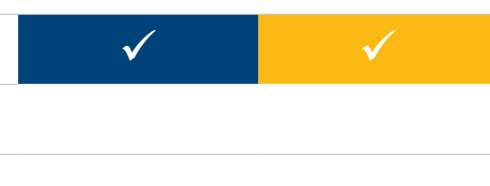

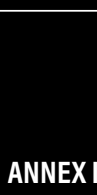

ANNEXI

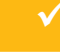

\section{NON-ANNEXI}

\begin{tabular}{|l|l} 
& \\
NON-ANNEXI & COM
\end{tabular}

DEVELOPMENT ASSISTANCE COMMITTEE MEMBER (ODA CONTRIBUTORS)

\section{OECD ODA STATUS \\ OECD ODA STATUS}

ODA INELIGIBLE (2013-18)
ODA ELIGIBLE

(2013-18)
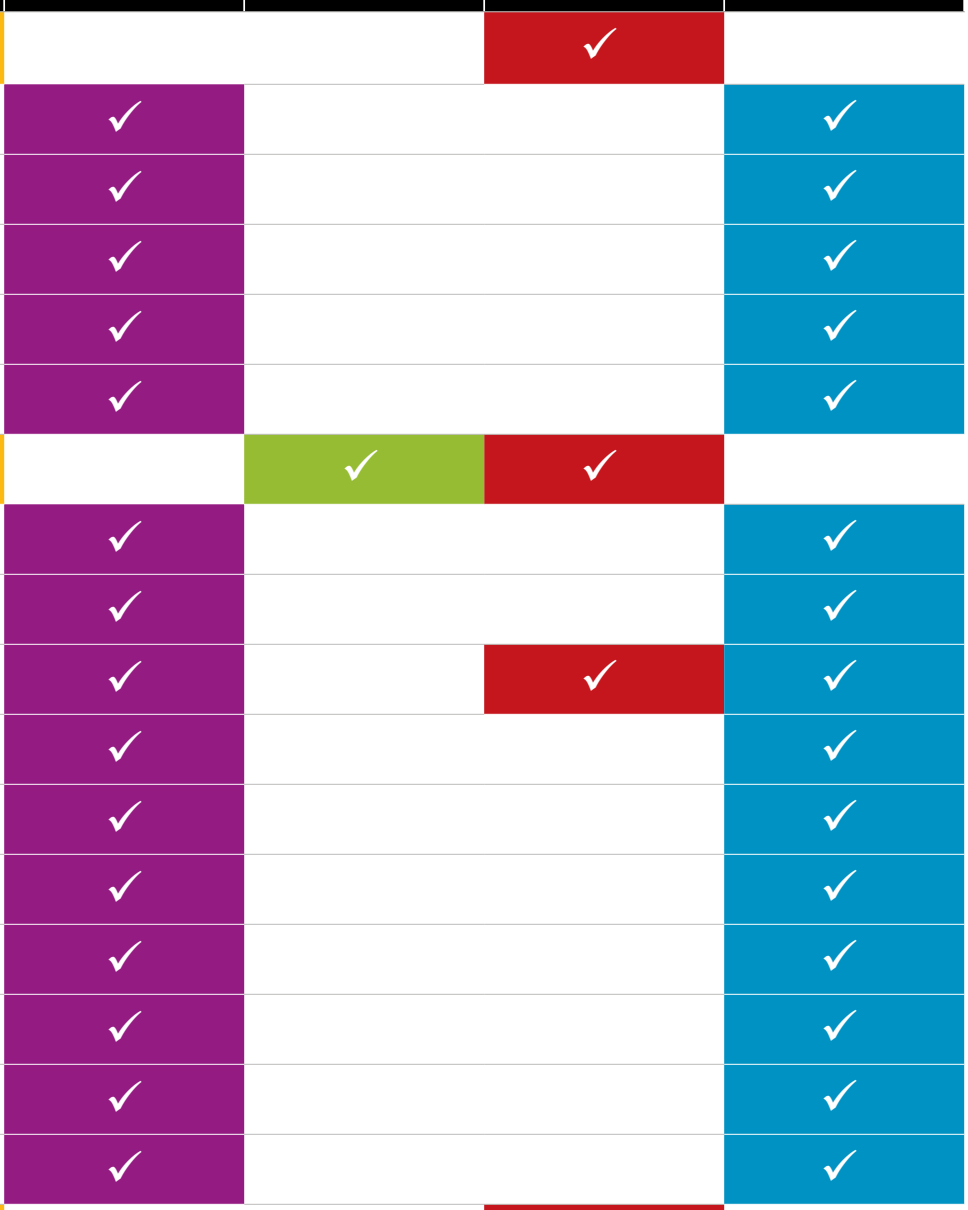
Table A1 | Status of Countries in the UNFCCC and OECD ODA Categories (cont.)
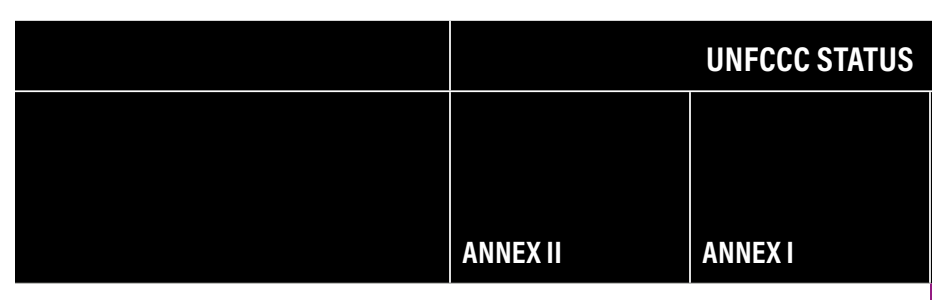

Dominican Republic

Ecuador

Egypt

El Salvador

Equatorial Guinea

\section{Eritrea}

Estonia

Eswatini

Ethiopia

\section{European Union}

Fiji

Finland

France

Gabon

Gambia

Georgia

Germany

Ghana

Greece

Grenada

Guatemala

Guinea

Guinea-Bissau

Guyana

Haiti
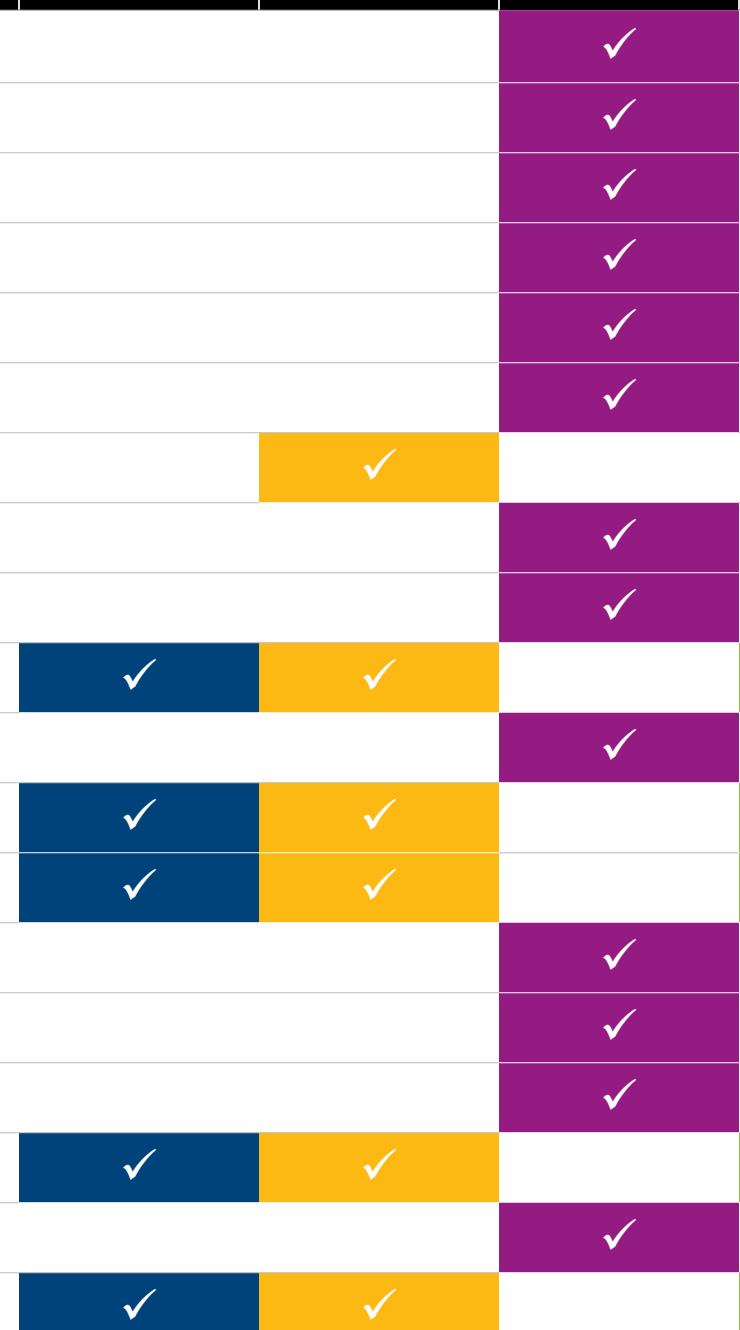

\section{NON-ANNEXI}
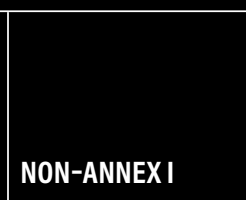

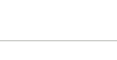


Table A1 | Status of Countries in the UNFCCC and OECD ODA Categories (cont.)

\begin{tabular}{|c|c|c|c|c|c|c|}
\hline & \multicolumn{3}{|c|}{ UNFCCC STATUS } & \multicolumn{3}{|c|}{ OECD ODA STATUS } \\
\hline & ANNEX II & ANNEXI & NON-ANNEXI & $\begin{array}{r}\text { DEVELOPMENT } \\
\text { ASSISTANCE } \\
\text { COMMITTEE } \\
\text { MEMBER (ODA } \\
\text { CONTRIBUTORS) }\end{array}$ & $\begin{array}{r}\text { ODA INELIGIBLE } \\
(2013-18)\end{array}$ & $\begin{array}{r}\text { ODA ELIGIBLE } \\
(2013-18)\end{array}$ \\
\hline Honduras & & & $\checkmark$ & & & $\checkmark$ \\
\hline Hungary & & $\checkmark$ & & $\sqrt{ }$ & $\checkmark$ & \\
\hline Iceland & $\sqrt{ }$ & $\checkmark$ & & $\sqrt{ }$ & $\checkmark$ & \\
\hline India & & & $\checkmark$ & & & $\checkmark$ \\
\hline Indonesia & & & $\checkmark$ & & & $\checkmark$ \\
\hline Iran (Islamic Republic of) & & & $\sqrt{ }$ & & & $\checkmark$ \\
\hline Iraq & & & $\sqrt{ }$ & & & $\sqrt{ }$ \\
\hline Ireland & $\sqrt{ }$ & $\checkmark$ & & $\checkmark$ & $\checkmark$ & \\
\hline Israel & & & $\sqrt{ }$ & & $\sqrt{ }$ & \\
\hline Italy & $\sqrt{ }$ & $\checkmark$ & & $\sqrt{ }$ & $\checkmark$ & \\
\hline Jamaica & & & $\checkmark$ & & & $\sqrt{ }$ \\
\hline Japan & $\sqrt{ }$ & $\checkmark$ & & $\sqrt{ }$ & $\checkmark$ & \\
\hline Jordan & & & $\checkmark$ & & & $\checkmark$ \\
\hline Kazakhstan & & & $\checkmark$ & & & $\sqrt{ }$ \\
\hline Kenya & & & $\sqrt{ }$ & & & $\sqrt{ }$ \\
\hline Kiribati & & & $\checkmark$ & & & $\checkmark$ \\
\hline Kuwait & & & $\checkmark$ & & $\checkmark$ & \\
\hline Kyrgyzstan & & & $\sqrt{ }$ & & & $\checkmark$ \\
\hline Lao People's Democratic Republic & & & $\checkmark$ & & & $\checkmark$ \\
\hline Latvia & & $\checkmark$ & & & $\checkmark$ & \\
\hline Lebanon & & & $\checkmark$ & & & $\checkmark$ \\
\hline Lesotho & & & $\checkmark$ & & & $\checkmark$ \\
\hline Liberia & & & $\checkmark$ & & & $\checkmark$ \\
\hline Libya & & & $\checkmark$ & & & $\checkmark$ \\
\hline Liechtenstein & & $\checkmark$ & & & $\checkmark$ & \\
\hline
\end{tabular}


Table A1 | Status of Countries in the UNFCCC and OECD ODA Categories (cont.)
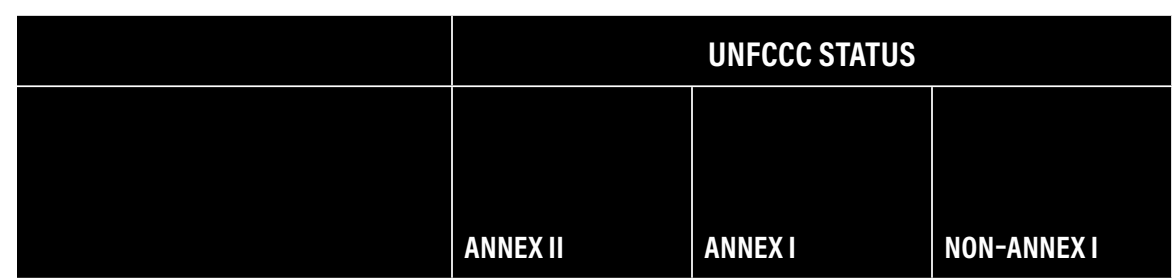

\begin{tabular}{|r|}
$\mid$ \\
OECD \\
DEVELOPMENT \\
ASSISTANCE \\
COMMITTEE \\
MEMBER (ODA \\
CONTRIBUTORS)
\end{tabular}

\section{OECD ODA STATUS}

Lithuania

Luxembourg

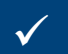

Madagascar

Malawi

Malaysia

Malawi

Malaysia

Maldives

Mali

Malta

Marshall Islands

Mauritania

Mexico

Micronesia (Federated States of)

Monaco

Mongolia

Montenegro

Morocco

Mozambique

Myanmar

Namibia

Nauru

Nepal

Netherlands

New Zealand
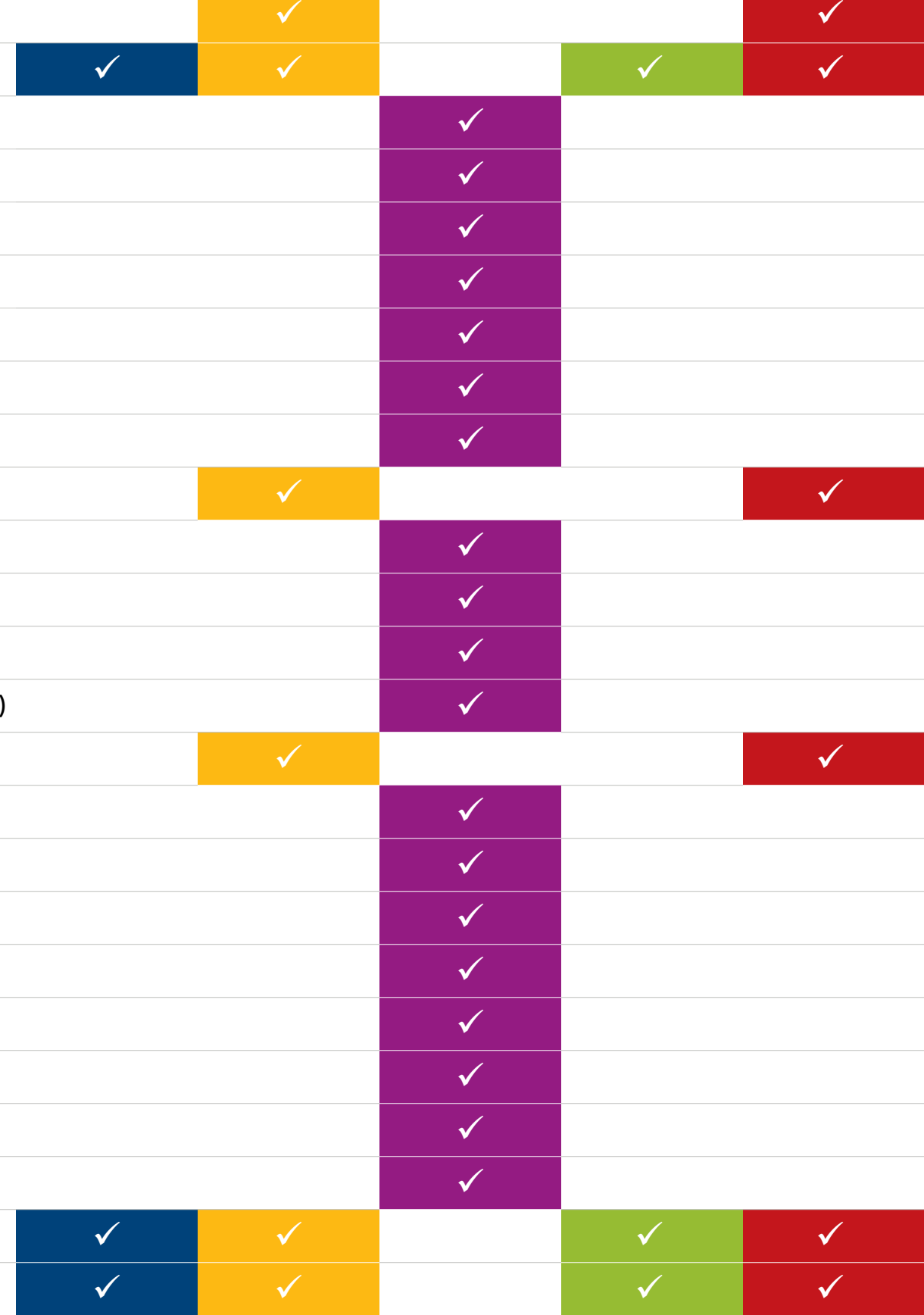

ODA INELIGIBLE

Nicaragua

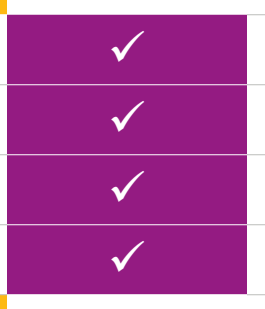

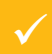
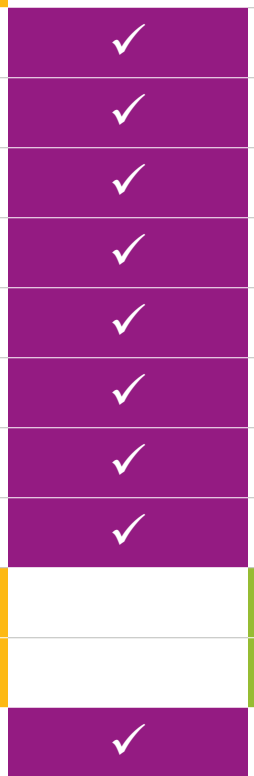
(2013-18)

ODA ELIGIBLE (2013-18)

ODA ELIGIBLE
$(2013-18)$
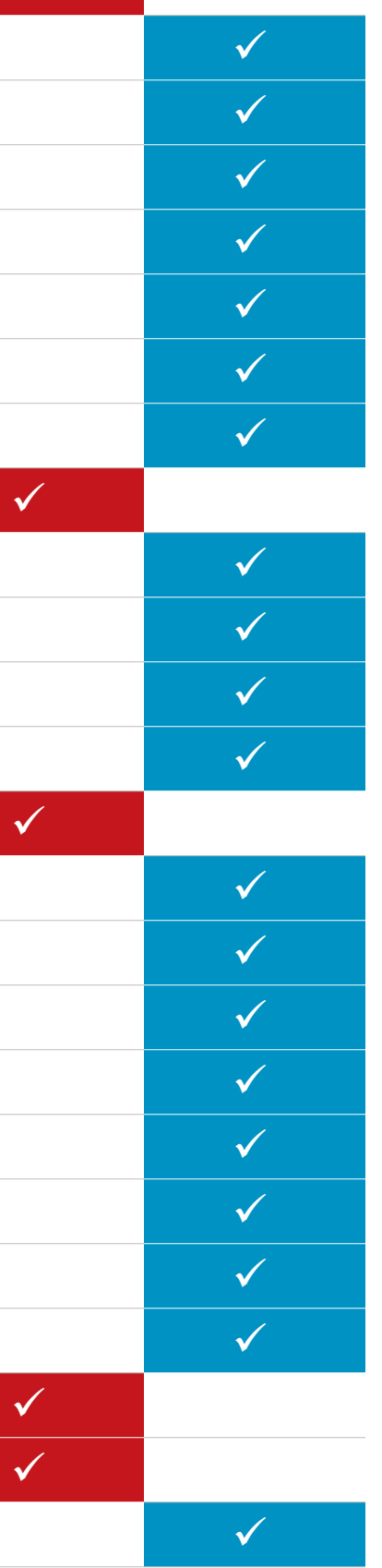
Table A1 | Status of Countries in the UNFCCC and OECD ODA Categories (cont.)

\begin{tabular}{|c|c|c|c|c|c|c|}
\hline & \multicolumn{3}{|c|}{ UNFCCC STATUS } & \multicolumn{3}{|c|}{ OECD ODA STATUS } \\
\hline & ANNEX II & ANNEXI & NON-ANNEX I & $\begin{array}{r}\text { DEVELOPMENT } \\
\text { ASSISTANCE } \\
\text { COMMIITEE } \\
\text { MEMBER (ODA } \\
\text { CONTRIBUTORS) }\end{array}$ & $\begin{array}{r}\text { ODA INELIGIBLE } \\
(2013-18)\end{array}$ & $\begin{array}{r}\text { ODA ELIGIBLE } \\
(2013-18)\end{array}$ \\
\hline Niger & & & $\checkmark$ & & & $\sqrt{ }$ \\
\hline Nigeria & & & $\checkmark$ & & & $\checkmark$ \\
\hline Niue & & & $\checkmark$ & & & $\sqrt{ }$ \\
\hline Norway & $\checkmark$ & v & & $\sqrt{ }$ & $\checkmark$ & \\
\hline Oman & & & $\checkmark$ & & $\checkmark$ & \\
\hline Pakistan & & & $\checkmark$ & & & $\checkmark$ \\
\hline Palau & & & $\checkmark$ & & & $\sqrt{ }$ \\
\hline Panama & & & $\checkmark$ & & & $\sqrt{ }$ \\
\hline Papua New Guinea & & & $\checkmark$ & & & $\sqrt{ }$ \\
\hline Paraguay & & & $\checkmark$ & & & $\sqrt{ }$ \\
\hline Peru & & & $\checkmark$ & & & $\sqrt{ }$ \\
\hline Philippines & & & $\checkmark$ & & & $\checkmark$ \\
\hline Poland & & $v$ & & $\sqrt{ }$ & $\checkmark$ & \\
\hline Portugal & $\sqrt{ }$ & $v$ & & $\sqrt{ }$ & $\sqrt{ }$ & \\
\hline Qatar & & & $\sqrt{ }$ & & $\sqrt{ }$ & \\
\hline Republic of Korea & & & $\checkmark$ & $\sqrt{ }$ & $\checkmark$ & \\
\hline Republic of Moldova & & & $\checkmark$ & & & $\checkmark$ \\
\hline Romania & & $v$ & & & $\checkmark$ & \\
\hline Russian Federation & & $\checkmark$ & & & $\checkmark$ & \\
\hline Rwanda & & & $\sqrt{ }$ & & & $\checkmark$ \\
\hline Saint Kitts and Nevis & & & $\checkmark$ & & $\checkmark$ & $\sqrt{ }$ \\
\hline Saint Lucia & & & $\checkmark$ & & & $\sqrt{ }$ \\
\hline Saint Vincent and the Grenadines & & & $\sqrt{ }$ & & & $\sqrt{ }$ \\
\hline Samoa & & & $\checkmark$ & & & $\sqrt{ }$ \\
\hline San Marino & & & $\checkmark$ & & $\checkmark$ & \\
\hline São Tomé and Príncipe & & & $\checkmark$ & & & $\sqrt{ }$ \\
\hline
\end{tabular}


Table A1 | Status of Countries in the UNFCCC and OECD ODA Categories (cont.)

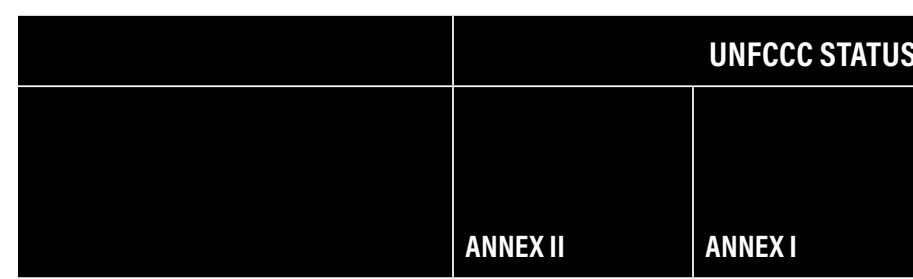

Saudi Arabia

Senegal

Serbia

Seychelles

Sierra Leone

Singapore

Slovakia

Slovenia

Solomon Islands

Somalia

South Africa

South Sudan

Spain

Sri Lanka

State of Palestine

Sudan

Suriname

Sweden

Switzerland

Syrian Arab Republic

Tajikistan

Thailand

The Republic of North Macedonia

Timor-Leste

Togo

Tonga
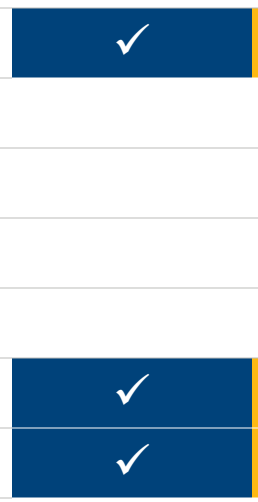

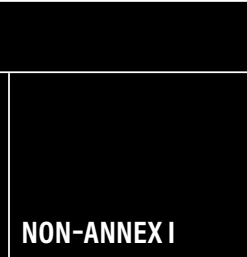

\section{NON-ANNEXI}
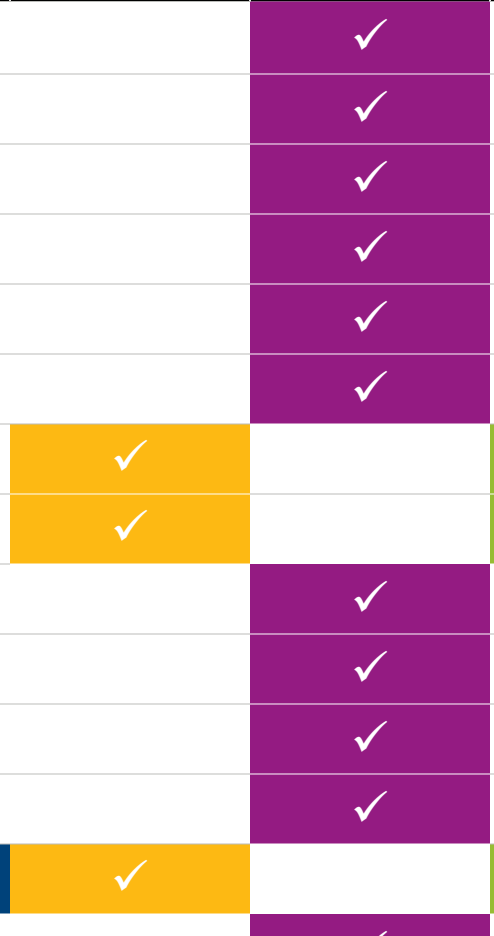

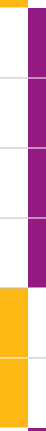

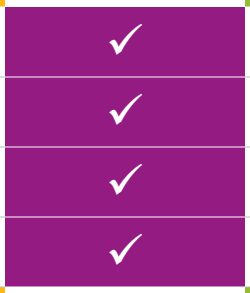

\begin{tabular}{|r|}
\hline \\
DEVELOPMENT \\
ASSISTANCE \\
COMMITTEE \\
MEMBER (ODA \\
CONTRIBUTORS) \\
\hline
\end{tabular}

OECD ODA STATUS

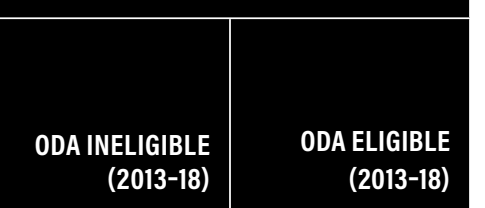

$\sqrt{ }$

(2013-18)
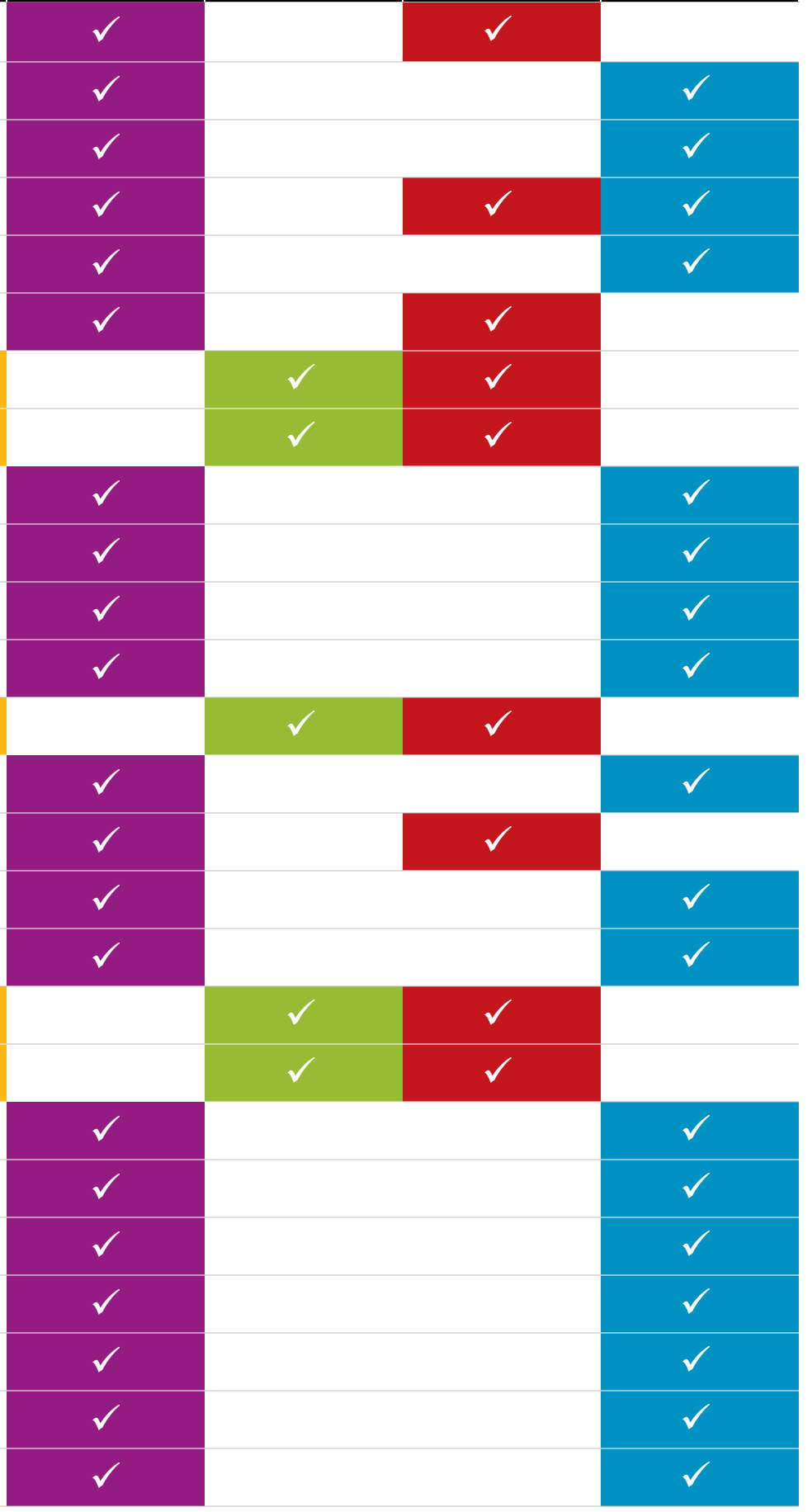
Table A1 | Status of Countries in the UNFCCC and OECD ODA Categories (cont.)

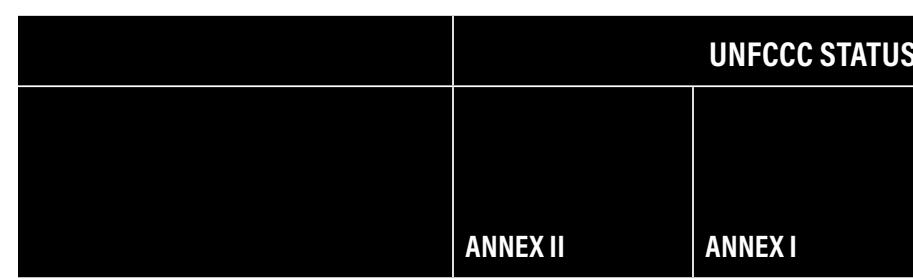

Trinidad and Tobago

Tunisia

Turkey

Turkmenistan

Tuvalu

Uganda

Ukraine

United Arab Emirates

United Kingdom of Great Britain and Northern Ireland

United Republic of Tanzania

United States of America

Uruguay

Uzbekistan

Vanuatu

Venezuela (Bolivarian Republic of)

Viet Nam

Yemen

Zambia

Zimbabwe

Number of countries in category
24

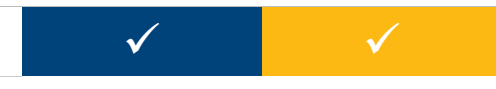

43
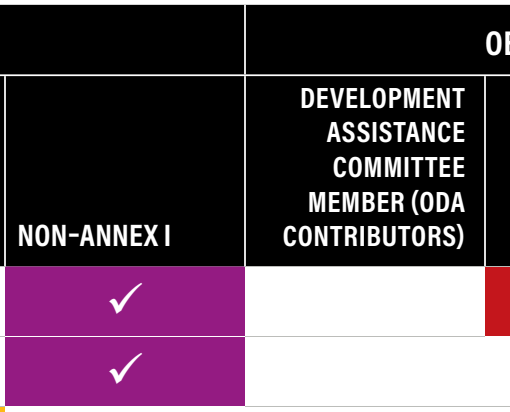

OECD ODA STATUS
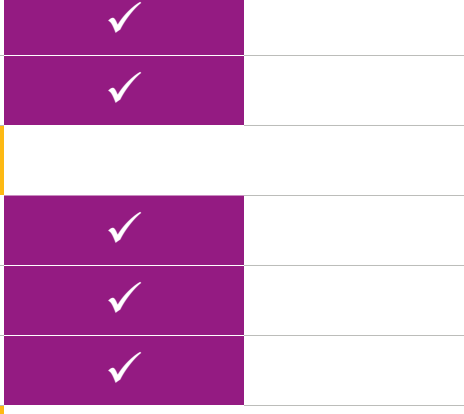

ODA INELIGIBLE (2013-18)
ODA ELIGIBLE (2013-18)

ODA ELIGIBLE
$(2013-18)$

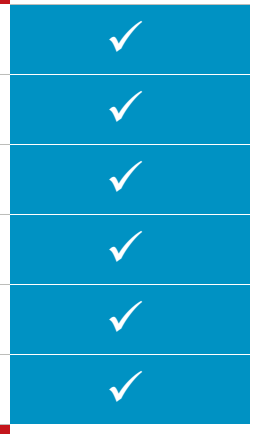

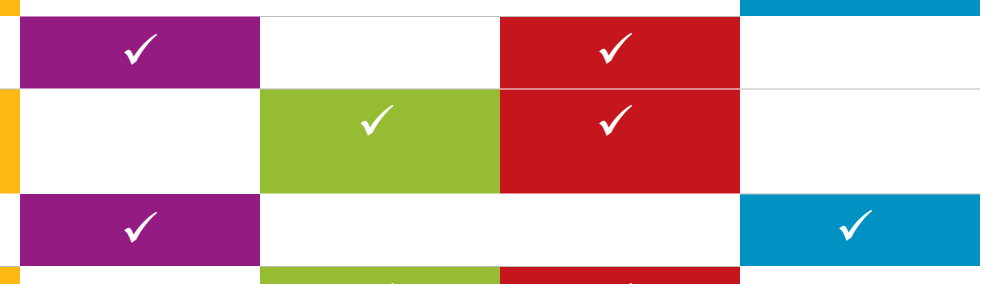

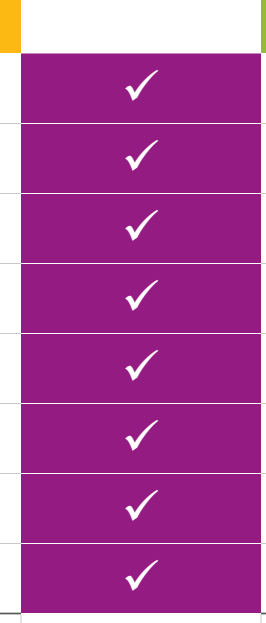

154

Notes: $\mathrm{ODA}=$ official development assistance; $\mathrm{OECD}=$ Organisation for Economic Co-operation and Development; UNFCCC = United Nations Framework Convention on Climate Change. a. Graduated from ODA eligibility in 2014.

b. Graduated from ODA eligibility in 2018.

Sources: WRI authors, based on OECD (2012, 2014, 2018a) and UNFCCC (2018a). 
ABBREVIATIONS

$\begin{array}{ll}\text { ADB } & \text { Asian Development Bank } \\
\text { ADF } & \text { Asian Development Fund } \\
\text { AfDB } & \text { African Development Bank } \\
\text { AfDF } & \text { African Development Fund } \\
\text { AIIB } & \text { Asian Infrastructure Investment Bank } \\
\text { BA } & \text { Biennial Assessment } \\
\text { BR } & \text { Biennial Report } \\
\text { CGD } & \text { Center for Global Development } \\
\text { COP } & \text { Conference of the Parties } \\
\text { CRS } & \text { Creditor Reporting System } \\
\text { CTF } & \text { common tabular format } \\
\text { DAC } & \text { Development Assistance Committee } \\
\text { EIB } & \text { European Investment Bank } \\
\text { EBRD } & \text { European Bank for Reconstruction and Development }\end{array}$

ETH Zurich Eidgenössische Technische Hochschule Zürich (Swiss Federal Institute of Technology Zurich)

FSO Fund for Special Operations

GCF Green Climate Fund

GDP gross domestic product

GHG greenhouse gas

GNI gross national income

G7 Group of Seven

IBRD International Bank for Reconstruction and Development

IDA International Development Association

IDBG Inter-American Development Bank Group

IFC International Finance Corporation

IIC Inter-American Investment Corporation

IMT indicative minimum threshold

MDB multilateral development bank

MIGA Multilateral Investment Guarantee Agency

NDC nationally determined contribution

ODA official development assistance

ODI Overseas Development Institute

OECD Organisation for Economic Co-operation and Development

SCF Standing Committee on Finance

UNFCCC United Nations Framework Convention on Climate Change

UNSG United Nations Secretary-General

WBG World Bank Group
1 The period 2010-12 was the "Fast-Start Finance" period, covered by a previous WRI and ODI analysis (Fransen et al. 2013).

2 Australia, Austria, Belarus, Belgium, Bulgaria, Canada, Croatia, Cyprus, Czechia, Denmark, the European Union, Estonia, Finland, France, Germany, Greece, Hungary, Iceland, Ireland, Italy, Japan, Latvia, Liechtenstein, Lithuania, Luxembourg, Malta, Monaco, Netherlands, New Zealand, Norway, Poland, Portugal, Romania, Russian Federation, Slovakia, Slovenia, Spain, Sweden, Switzerland, Turkey, Ukraine, the United Kingdom, and the United States.

3 The multilateral climate change funds listed are as follows: 1. Global Environment Facility, 2. Least Developed Countries Fund, 3. Special Climate Change Fund, 4. Adaptation Fund, 5. Green Climate Fund, 6. UNFCCC Trust Fund for Supplementary Activities. The multilateral financial institutions, including regional development banks, listed are as follows: 1. World Bank, 2. International Finance Corporation, 3. African Development Bank, 4. Asian Development Bank, 5. European Bank for Reconstruction and Development, 6. Inter-American Development Bank. The specialized United Nations bodies listed are as follows: 1. United Nations Development Programme (specific programs), 2. United Nations Environment Programme (specific programs) (UNFCCC 2012).

4 The African Development Bank, Asian Development Bank, Asian Infrastructure Investment Bank, European Bank for Reconstruction and Development, European Investment Bank, Inter-American Development Bank Group, and World Bank Group.

5 In its first Climate Vulnerable's Finance Summit, the V20 group of finance ministers from climate-vulnerable countries stated in its communique, "We are specifically demanding a joint 'Delivery Plan' from the developed nations to concretely demonstrate how the $\$ 100$ billion in annual climate finance will be met over the 5 years' period from 2020 to 2024 with in total a minimum of $\$ 500$ billion of climate finance provided" (V20 2021).

6 As discussed earlier, in its first Climate Vulnerable's Finance Summit, the V20 group of finance ministers from climate-vulnerable countries stated in its communique, "We are specifically demanding a joint 'Delivery Plan' from the developed nations to concretely demonstrate how the $\$ 100$ billion in annual climate finance will be met over the 5 years' period from 2020 to 2024 with in total a minimum of $\$ 500$ billion of climate finance provided" (V20 2021). 
REFERENCES

ADB (Asian Development Bank). 2014a. "Members, Capital Stock, and Voting Power." In Asian Development Bank Annual Report 2013: Promoting Environmentally Sustainable Growth in Asia and the Pacific. Manila: ADB. https://www.adb.org/ sites/default/files/institutional-document/42741/0i-appendix1.pdf.

ADB. 2014b. "Special Purpose Statement of Resources." In Asian Development Bank Financial Report 2013: Management's Discussion and Analysis and Annual Financial Statements. Manila: ADB. https://www.adb.org/sites/default/files/ institutional-document/42741/adb-financial-report-2013.pdf.

ADB. 2015a. "Members, Capital Stock, and Voting Power." In Asian Development Bank Annual Report 2014: Improving Lives throughout Asia and the Pacific. Manila: ADB. https://www.adb.org/sites/default/files/institutional-document/158032/ oi-appendix1.pdf.

ADB. 2015b. "Special Purpose Statement of Resources." In Asian Development Bank Financial Report 2014: Management's Discussion and Analysis and Annual Financial Statements. Manila: ADB. https://www.adb.org/sites/default/files/ institutional-document/158032/adb-financial-report-2014.pdf.

ADB. 2016a. "Members, Capital Stock, and Voting Power." In Asian Development Bank Annual Report 2015: Scaling Up to Meet New Development Challenges. Manila: ADB. https://www.adb.org/sites/default/files/institutionaldocument/218696/oi-appendix1.pdf.

ADB. 2016b. "Special Purpose Statement of Resources." In Asian Development Bank Financial Report 2015: Management's Discussion and Analysis and Annual Financial Statements. Manila: ADB. https://www.adb.org/sites/default/files/ institutional-document/182852/adb-financial-report-2015.pdf.

ADB. 2016c. 2015 Joint Report on Multilateral Development Banks'Climate Finance. Manila: ADB. https://www.adb.org/sites/default/files/institutionaldocument/189560/mdb-joint-report-2015.pdf.

ADB. 2017a. "Members, Capital Stock, and Voting Power." In Asian Development Bank Annual Report 2016: 50 Years of ADB-Improving Lives for a Better Future. Manila: ADB. https://www.adb.org/sites/default/files/institutionaldocument/414776/oi-appendix1.pdf.

ADB. 2017b. "Special Purpose Statement of Resources." In Asian Development Bank Financial Report 2016: Management's Discussion and Analysis and Annual Financial Statements. Manila: ADB. https://www.adb.org/sites/default/files/ institutional-document/414776/adb-financial-report-2016.pdf.

ADB. 2018a. "Members, Capital Stock, and Voting Power." In Asian Development Bank Annual Report 2017: Sustainable Infrastructure for Future Needs. Manila: ADB. https://data.adb.org/node/4306/download.

ADB. 2018b. "Special Purpose Statement of Resources." In Asian Development Bank Financial Report 2017: Management's Discussion and Analysis and Annual Financial Statements. Manila: ADB. https://www.adb.org/sites/default/files/ institutional-document/411996/adb-financial-report-2017.pdf.

ADB. 2019a. "Members, Capital Stock, and Voting Power." In Asian Development Bank Annual Report 2018: Working Together for a Prosperous, Inclusive, Resilient, and Sustainable Asia and the Pacific. Manila: ADB. https://data.adb.org/ node/7091/download.

ADB. 2019b. "Special Purpose Statement of Resources." In Asian Development Bank Financial Report 2018: Management's Discussion and Analysis and Annual
Financial Statements. Manila: ADB. https://www.adb.org/sites/default/files/ institutional-document/496016/adb-financial-report-2018.pdf.

AfDB (African Development Bank). 2014. African Development Bank Annual Report 2013. Tunis: Department of Development Research, AfDB. https://www.afdb.org/ en/documents/document/annual-report-2013-48189.

AfDB. 2015. African Development Bank Annual Report 2014. Abidjan: Department of Development Research, AfDB. https://www.afdb.org/en/documents/document/ annual-report-2014-53328.

AfDB. 2016. African Development Bank Annual Report 2015. Abidjan: Department of Development Research, AfDB. https://www.afdb.org/en/documents/document/ afdb-annual-report-2015-88761.

AfDB. 2017. African Development Bank Annual Report 2016: Financial Management and Financial Statements, Year Ended 31 December 2016. Abidjan: Department of Development Research, AfDB. https://www.afdb.org/fileadmin/uploads/afdb/ Documents/Generic-Documents/AfDB_Financial_Report_2016_EN.pdf.

AfDB. 2018. African Development Bank Annual Report 2017: Financial Management and Financial Statements, Year Ended 31 December 2017. Abidjan: Department of Development Research, AfDB. https://www.afdb.org/fileadmin/uploads/afdb/ Documents/Generic-Documents/AfDB_Financial_Report_2017_EN.pdf.

AfDB. 2019. African Development Bank Financial Report 2018: Financial Management and Financial Statements, Year Ended 31 December 2018. Abidjan: AfDB. https://www.afdb.org/en/documents/financial-report-2018.

AllB (Asian Infrastructure Investment Bank). 2021. "Members and Prospective Members of the Bank." August 24. https://www.aiib.org/en/about-aiib/ governance/members-of-bank/index.html.

Bhattacharya, A., R. Calland, A. Averchenkova, L. Gonzalez, L. Martinez-Diaz, and J. Van Rooij. 2020. Delivering on the $\$ 100$ Billion Climate Finance Commitment and Transforming Climate Finance. New York: Independent Expert Group on Climate Finance, United Nations Secretary-General. https://www.un.org/sites/un2.un.org/ files/100_billion_climate_finance_report.pdf.

Bodnar, $P_{1}$, J. Brown, and S. Nakhooda. 2015. "What Counts: Tools to Help Define and Understand Progress towards the \$100 Billion Climate Finance Commitment." Working Paper. Washington, DC: World Resources Institute. https://www.wri.org/ research/what-counts-tools-help-define-and-understand-progress-towards-100billion-climate-finance.

Carty, T., J. Kowalzig, and A. Peterson. 2016. Climate Finance Shadow Report 2016: Lifting the Lid on Progress towards the $\$ 100$ Billion Commitment. Oxford, UK: Oxfam. https://www.oxfam.org/en/research/climate-finance-shadow-report-2016.

Carty, T., J. Kowalzig, and B. Zagema. 2020. Climate Finance Shadow Report 2020: Assessing Progress towards the $\$ 100$ Billion Commitment, Oxford, UK: Oxfam. https://oxfamilibrary.openrepository.com/bitstream/handle/10546/621066/bpclimate-finance-shadow-report-2020-201020-en.pdf.

Carty, T., and A. Le Comte. 2018. Climate Finance Shadow Report 2018: Assessing Progress towards the $\$ 100$ Billion Commitment. Oxford, UK: Oxfam. https://www.oxfam.org/en/research/climate-finance-shadow-report-2018.

Colenbrander, S., Y. Ca0, and L. Pettinotti. 2021. "A Fair Share of Climate Finance? An Initial Effort to Apportion Responsibility for the $\$ 100$ Billion Climate Finance Goal." ODI Emerging Analysis Paper. London: Overseas Development Institute. https://cdn.odi.org/media/documents/Emerging_analysis___apportioning_ the_100_billion_climate_finance_goal_rev2607_8kc1Pmt.pdf. 
EBRD (European Bank for Reconstruction and Development). 2017. 2016 Joint Report on Multilateral Development Banks'Climate Finance. London: EBRD. https:// www.ebrd.com/documents/climate-finance/2016-joint-report-on-multilateraldevelopment-banks-climate-finance.pdf.

EBRD. 2018. 2017 Joint Report on Multilateral Development Banks' Climate Finance. London: EBRD. https://www.ebrd.com/2017-joint-report-on-mdbs-climate-finance.

EBRD. 2019. 2018 Joint Report on Multilateral Development Banks' Climate Finance. London: EBRD. https://www.ebrd.com/2018-joint-report-on-mdbsclimate-finance.

EBRD. n.d. "EBRD Shareholders and Board of Governors." https://www.ebrd.com/ shareholders-and-board-of-governors.html. Accessed September 8, 2021.

Egli, F., and A. Stünzi. 2019. "A Dynamic Climate Finance Allocation Mechanism Reflecting the Paris Agreement." Environmental Research Letters 14 (11): 114024. https://doi.org/10.1088/1748-9326/ab443b.

EIB (European Investment Bank). 2014. Joint Report on MDB Climate Finance 2013. Luxembourg: EIB. https://www.eib.org/attachments/documents/joint_report_ on_mdb_climate_finance_2013.pdf.

EIB. 2019. Financial Report 2018. Luxembourg: ElB. https://www.eib.org/ attachments/general/reports/eib_financial_report_2018_en.pdf.

EU (European Union). 2009. "Directive 2009/28/EC of the European Parliament and of the Council on the Promotion of the Use of Energy from Renewable Sources and Amending and Subsequently Repealing Directives 2001/77/EC and 2003/30/ EC." Official Journal of the European Union 140/16 (May). http://eur-lex.europa.eu/ legal-content/EN/TXT/PDF/?uri=CELEX:32009L0028\&from=EN.

EU. 2014. EU Budget 2013: Financial Report. Brussels: European Union. https://op.europa.eu/en/publication-detail/-/publication/c025d261-c65d-4a91a9f9-12c6e6a77c7a.

EU. 2015. EU Budget 2014: Financial Report. Brussels: European Union. https://ec.europa.eu/budget/financialreport/2014/lib/financial_ report_2014_en.pdf.

EU. 2016. EU Budget 2015: Financial Report. Brussels: European Union. https://op.europa.eu/en/publication-detail/-/publication/af9650e2-bd17-11e6a237-01aa75ed71a1.

EU. 2017. EU Budget 2016: Financial Report. Brussels: European Union. https://ec.europa.eu/budget/library/biblio/publications/2017/ financial-report_en.pdf.

EU. 2018. EU Budget 2017: Financial Report. Brussels: European Union. https://ec.europa.eu/budget/library/biblio/publications/2018/ financial-report_en.pdf.

EU. 2019. EU Budget 2018: Financial Report. Brussels: European Union. https://ec.europa.eu/info/sites/info/files/about_the_european_commission/ eu_budget/financial_report_web.pdf.

EU Council. 2018. "Climate Finance: Council Adopts Conclusions ahead of COP24 Conference." Press Release, November 6. https://www.consilium.europa.eu/en/ press/press-releases/2018/11/06/2018-ecofin-climate-finance-conclusions/.

Fransen, T., S. Nakhooda, T. Kuramochi, A. Caravani, A. Prizzon, N. Shimizu, H. Tilley, A. Halimanjaya, and B. Welham. 2013. Mobilising International Climate Finance: Lessons from the Fast-Start Finance Period. Washington, DC: World Resources
Institute; London: Overseas Development Institute; Kanagawa, Japan: Institute for Global Environmental Strategies, https://www.wri.org/research/mobilisinginternational-climate-finance.

IBRD (International Bank for Reconstruction and Development). 2013. Management's Discussion \& Analysis and Financial Statements June 30, 2013. Washington, DC: IBRD. http://pubdocs.worldbank.org/en/109961586359945945/ IBRD-Financial-Statements-June-2013.pdf.

IBRD. 2014. Management's Discussion \& Analysis and Financial Statements June 30, 2014. Washington, DC: IBRD. http://pubdocs.worldbank.org/ en/280321586359845072/IBRD-Financial-Statements-June-2014.pdf.

IBRD. 2015. Management's Discussion \& Analysis and Financial Statements June 30, 2015. Washington, DC: IBRD. http://pubdocs.worldbank.org/ en/933611586359723822/IBRD-Financial-Statements-June-2015.pdf.

IBRD. 2016. Management's Discussion \& Analysis and Financial Statements June 30, 2016. Washington, DC: IBRD. http://pubdocs.worldbank.org/ en/536371586359630422/IBRD-Financial-Statements-June-2016.pdf.

IBRD. 2017. Management's Discussion \& Analysis and Financial Statements June 30, 2017. Washington, DC: IBRD. http://pubdocs.worldbank.org/ en/395711586359521179//BRD-Financial-Statements-June-2017.pdf.

IBRD. 2018. Management's Discussion \& Analysis and Financial Statements June 30, 2018. Washington, DC: IBRD. http://pubdocs.worldbank.org/ en/653521565271152351//BRD-Financial-Statements-June-2018.pdf.

IDA (International Development Association). 2013. Management's Discussion \& Analysis and Financial Statements June 30, 2013. Washington, DC: IDA. http://pubdocs.worldbank.org/en/937621586358888249/IDA-FinancialStatements-June-2013.pdf.

IDA. 2014. Management's Discussion \& Analysis and Financial Statements June 30, 2014. Washington, DC: IDA. http://pubdocs.worldbank.org/ en/932381586358707781/IDA-Financial-Statements-June-2014.pdf.

IDA. 2015. Management's Discussion \& Analysis and Financial Statements June 30, 2015. Washington, DC: IDA. http://pubdocs.worldbank.org/ en/660501586358616454/IDA-Financial-Statements-June-2015.pdf.

IDA. 2016. Management's Discussion \& Analysis and Financial Statements June 30, 2016. Washington, DC: IDA. http://pubdocs.worldbank.org/ en/823381586356976283/IDA-Financial-Statements-June-2016.pdf.

IDA. 2017. Management's Discussion \& Analysis and Financial Statements June 30, 2017. Washington, DC: IDA. http://pubdocs.worldbank.org/ en/152931586356333188/IDA-Financial-Statements-June-2017.pdf.

IDA. 2018. Management's Discussion \& Analysis and Financial Statements June 30, 2018. Washington, DC: IDA. http://pubdocs.worldbank.org/ en/315531585750105810/IDA-Financial-Statements-June-2018.pdf.

IDB (Inter-American Development Bank). 2014a. Inter-American Development Bank 2013 Annual Report: The Year in Review. Washington, DC: IDB.

https://publications.iadb.org/publications/english/document/Inter-AmericanDevelopment-Bank-Annual-Report-2013-The-Year-in-Review.pdf.

IDB. 2014b. Inter-American Development Bank 2013 Financial Statement. Washington, DC: IDB. https://publications.iadb.org/publications/english/ document/Inter-American-Development-Bank-Annual-Report-2013Financial-Statements.pdf. 
IDB. 2015a. Inter-American Development Bank 2014 Annual Report: The Year in Review. Washington, DC: IDB. https://publications.iadb.org/publications/ english/document/Inter-American-Development-Bank-Annual-Report-2014-TheYear-in-Review.pdf.

IDB. 2015b. Inter-American Development Bank 2014 Financial Statement. Washington, DC: IDB. https://publications.iadb.org/publications/english/ document/Inter-American-Development-Bank-Annual-Report-2014Financial-Statements.pdf.

IDB. 2016a. Inter-American Development Bank 2015 Annual Report: The Year in Review. Washington, DC: IDB. https://publications.iadb.org/publications/ english/document/Inter-American-Development-Bank-Annual-Report-2015-TheYear-in-Review.pdf.

IDB. 2016b. Inter-American Development Bank 2015 Financial Statement. Washington, DC: IDB. https://publications.iadb.org/publications/english/ document/Inter-American-Development-Bank-Annual-Report-2015Financial-Statements.pdf.

IDB. 2017a. Inter-American Development Bank 2016 Annual Report: The Year in Review. Washington, DC: IDB. https://publications.iadb.org/publications/ english/document/Inter-American-Development-Bank-Annual-Report-2016-TheYear-in-Review.pdf.

IDB. 2017b. Inter-American Development Bank 2016 Financial Statement. Washington, DC: IDB. https://publications.iadb.org/publications/english/ document/Inter-American-Development-Bank-Annual-Report-2016Financial-Statements.pdf.

IDB. 2018. Inter-American Development Bank 2017 Annual Report; The Year in Review. Washington, DC: IDB. https://publications.iadb.org/publications/english/document/ Inter-American-Development-Bank-Annual-Report-2017-The-Year-in-Review.pdf.

IDB. 2019. Inter-American Development Bank 2018 Annual Report: The Year in Review. Washington, DC: IDB. https://publications.iadb.org/publications/english/ document/Inter-American_Development_Bank_Annual_Report_2018_The_ Year_in_Review_en_en.pdf.

IDB Invest. 2018. Annual Report 2017. Washington, DC: IDB Invest. https://www.idbinvest.org/en/publications/2017-annual-report.

IDB Invest. 2019. Annual Report 2018. Washington, DC: IDB. https://www.idbinvest.org/en/publications/annual-report-2018.

IFC (International Finance Corporation). 2013. Management's Discussion and Analysis and Consolidated Financial Statements June 30, 2013. Washington, DC: IFC. http://documents.worldbank.org/curated/en/187871544075371014/ pdf/132673-FY13-ENGLISH-IFC-Financial-Statement-PUBLIC.pdf.

IFC. 2014. Management's Discussion and Analysis and Consolidated Financial Statements June 30, 2014. Washington, DC: IFC. https://www.ifc. org/wps/wcm/connect/c48966f0-5747-4407-994e-29a441510705/IFC++FY14+Q1-Q4+-+MDA+and+Consolidated+Financial+Statements+-+FINAL. pdf?MOD=AJPERES\&CVID=mN23mwE.

IFC. 2015. Management's Discussion and Analysis and Consolidated Financial Statements June 30, 2015. Washington, DC: IFC. https://www. ifc.org/wps/wcm/connect/46f470fb-8a6d-4c41-a397-4a37b9571c87/ IFC+-+FY15+Q1-Q4+-+MDA+and+Financial+Statements+-+FINAL. pdf?MOD=AJPERES\&CVID=mMGbLHO.
IFC. 2016. Management's Discussion and Analysis and Consolidated Financial Statements June 30, 2016. Washington, DC: IFC. https://www.ifc.org/wps/wcm/ connect/e98cafca-d809-4e37-803b-7bcbfa78aeb1/IFC+FY16+MDA+and+FS_ Final.pdf?MOD=AJPERES\&CVID=mMGdZnX

IFC. 2017. Management's Discussion and Analysis and Consolidated Financial Statements June 30, 2017. Washington, DC: IFC. https://www.ifc.org/wps/wcm/ connect/1653c590-623c-4f00-bb90-b18b6ea58d75/IFC+FY17+MDA+and+FS_ Final.pdf?MOD=AJPERES\&CVID=mMGdZQx.

IFC. 2018. Management's Discussion and Analysis and Consolidated Financial Statements June 30, 2018. Washington, DC: IFC. https://www.ifc.org/wps/wcm/ connect/f1226405-5844-4d45-8849-612126d02b52/IFC+FY18+MDA+and+FS_ Final.pdf?MOD=AJPERES\&CVID=mMGdN0j.

IIC (Inter-American Investment Corporation). 2014. 2013 Audited Financial Statements. Washington, DC: IIC. https://www.idbinvest.org/en/publications/ financial-statements-2013.

IIC. 2015. Audited Financial Statements as of December 31, 2014 and 2013. Washington, DC: IIC. https://idbinvest.org/en/publications/2014-financial-statements.

IIC. 2016. 2015 Annual Report. Washington, DC: IIC. https://www. Idbinvest.org/en/ publications/2015-annual-report.

IIC. 2017. 2016 Annual Report. Washington, DC: IIC. https://www.idbinvest.org/en/ publications/2016-annual-report.

Kowalzig, J. 2019. "Refilling the Green Climate Fund: Will Rich Countries' Pledges Match Expectations?" Deutsche Klimafinanzierung, May 13. https:// www.germanclimatefinance.de/2019/05/13/will-pledges-green-climate-fundmatch-expectations/.

Mitchell, I., E. Ritchie, and A. Tahmasebi. 2021. "Is Climate Finance towards $\$ 100$ Billion 'New and Additional'?" Policy Paper 205. Washington, DC: Center for Global Development. https://www.cgdev.org/publication/climate-finance-towards-100billion-new-and-additional.

OECD (Organisation for Economic Co-operation and Development). 2012. DAC List of ODA Recipients: Effective for Reporting on 2012 and 2013 Flows. Paris: OECD. https://www.oecd.org/dac/financing-sustainable-development/developmentfinance-standards/DAC List used for 2012 and 2013 flows.pdf.

OECD. 2014. DAC List of ODA Recipients: Effective for Reporting on 2014, 2015, 2016 and 2017 Flows. Paris: OECD. https://www.oecd.org/dac/ financing-sustainable-development/development-finance-standards/DAC_List_ ODA_Recipients2014to2017_flows_En.pdf.

OECD. 2015. Climate Finance in 2013-14 and the USD 100 Billion Goal: A Report by the OECD in Collaboration with Climate Policy Initiative. Paris: OECD. https://doi. org/10.1787/9789264249424-en.

OECD. 2018a. DAC List of ODA Recipients: Effective for Reporting on Aid in 2018 and 2019. Paris: OECD. https://www.oecd.org/dac/financing-sustainable-development/ development-finance-standards/DAC-List-of-ODA-Recipients-for-reporting-2018and-2019-flows.pdf.

OECD. 2018b. Methodological Note on the OECD-DAC Climate-Related Development Finance Databases. Paris: OECD. https://www.oecd.org/ dac/financing-sustainable-development/development-finance-data/ METHODOLOGICAL_NOTE.pdf. 
OECD. 2019. Climate Finance Provided and Mobilised by Developed Countries in 2013-17. Paris: OECD. https://doi.org/10.1787/39faf4a7-en.

OECD. 2020. Climate Finance Provided and Mobilised by Developed Countries in 2013-18. Paris: OECD. https://doi.org/10.1787/f0773d55-en.

OECD. 2021a. "Climate Change: OECD DAC External Development Finance Statistics - Imputed Multilateral Shares" OECD. https://www.oecd.org/dac/financingsustainable-development/development-finance-topics/climate-change.htm. Updated May 2021.

OECD. 2021b. "Exchange Rates." https://doi.org/10.1787/037ed317-en. Accessed September 1.

OECD. n.d. DAC Glossary of Key Terms and Concepts. Paris: OECD. Accessed September 1, 2021. https://www.oecd.org/dac/dac-glossary.htm.

Ritchie, H. 2019. "Who Has Contributed Most to Global CO Emissions?" Our World in Data. 2019. https://ourworldindata.org/contributed-most-global-c02.

Roberts, J.T., R. Weikmans, S.A. Robinson, D. Ciplet, M. Khan, and D. Falzon. 2021. "Rebooting a Failed Promise of Climate Finance." Nature Climate Change 11 (3): 180-82. https://doi.org/10.1038/s41558-021-00990-2.

SCF (Standing Committee on Finance). 2014. 2014 Biennial Assessment and Overview of Climate Finance Flows Report. Bonn, Germany: SCF, United Nations Framework Convention on Climate Change. http://unfccc.int/files/cooperation_ and_support/financial_mechanism/standing_committee/application/ pdf/2014_biennial_assessment_and_overview_of_climate_finance_flows_ report_web.pdf.

SCF. 2016. 2016 Biennial Assessment and Overview of Climate Finance Flows Report, Bonn, Germany: SCF, United Nations Framework Convention on Climate Change. http://unfccc.int/files/cooperation_and_support/financial_mechanism/ standing_committee/application/pdf/2016_ba_technical_report.pdf.

SCF. 2018. 2018 Biennial Assessment and Overview of Climate Finance Flows Technical Report. Bonn, Germany: SCF, United Nations Framework Convention on Climate Change. https://unfccc.int/sites/default/files/resource/2018\%20BA\%20 Technical\%20Report\%20Final\%20Feb\%202019.pdf.

Thwaites, J. 2018. "US 2018 Budget and Climate Finance: It's Bad, but Not as Bad as You Might Think." Insights (blog), March 23. https://www.wri.org/insights/us-2018budget-and-climate-finance-its-bad-not-bad-you-might-think.

Thwaites, J. 2019. "US Climate Finance Improves with 2019 Budget, but There's Still a Long Way to Go." Insights (blog), February 20. https://www.wri.org/insights/usclimate-finance-improves-2019-budget-theres-still-long-way-go.

TWG (Technical Working Group). 2015. "Accounting for Mobilized Private Climate Finance: Input to the OECD-CPI Report." Paris: TWG. Organisation for Economic Co-operation and Development. http://www.news.admin.ch/NSBSubscriber/ message/attachments/41225.pdf.

UN (United Nations). 1992. United Nations Framework Convention on Climate Change. New York: UN. https://treaties.un.org/Pages/ViewDetailsIII.

aspx?src=TREATY\&mtdsg_no=XXVII-7\&chapter=27\&Temp=mtdsg3\&clang=_en.

UNFCCC (United Nations Framework Convention on Climate Change). 2001. COP Decision 26/CP.7: Amendment to the List in Annex II to the Convention. Bonn, Germany: UNFCCC.
UNFCCC. 2009. COP Decision 2/CP.15: Copenhagen Accord. Bonn, Germany: UNFCCC. https://unfccc.int/resource/docs/2009/cop15/eng/11a01.pdf\#page =4

UNFCCC. 2010. COP Decision 1/CP.16: Cancun Agreements. Bonn, Germany: UNFCCC.

UNFCCC. 2012. COP Decision 19/CP.18: Common Tabular Format for "UNFCCC Biennial Reporting Guidelines for Developed Country Parties." Bonn, Germany: UNFCCC.

UNFCCC. 2015. COP Decision 1/CP.21: Adoption of the Paris Agreement. Bonn, Germany: UNFCCC. https://unfccc.int/resource/docs/2015/cop21/ eng/10a01.pdf\#page $=2$.

UNFCCC. 2016. "Second Biennial Reports-Annex I." https://unfccc.int/process-and-meetings/transparency-and-reporting/ reporting-and-review-under-the-convention/national-communicationsand-biennial-reports-annex-i-parties/biennial-report-submissions/ second-biennial-reports-annex-i.

UNFCCC. 2018a. "Parties." August 7. https://unfccc.int/process/parties-non-partystakeholders/parties-convention-and-observer-states.

UNFCCC. 2018b. "Third Biennial Reports-Annex I." https://unfccc.int/process-and-meetings/transparency-and-reporting/ reporting-and-review-under-the-convention/national-communicationsand-biennial-reports-annex-i-parties/biennial-report-submissions/ third-biennial-reports-annex-i.

UNFCCC. 2020. "Fourth Biennial Reports-Annex I." https://unfccc.int/BRs.

UNGA (United Nations General Assembly). 2018. Scale of Assessments for the Apportionment of the Expenses of the United Nations. A/RES/73/271. New York: UNGA. https://undocs.org/en/A/RES/73/271.

V20 (Vulnerable 20 Group of Ministers of Finance). 2021. "1st Climate Vulnerable's Finance Summit Communiqué." July 8. https://www.v-20.org/activities/ ministerial/1st-climate-vulnerables-finance-summit-communique.

Waslander, J., and P. Quijano Vallejos. 2018. "Setting the Stage for the Green Climate Fund's First Replenishment." Working Paper. Washington, DC: World Resources Institute. https://www.wri.org/research/setting-stage-green-climatefunds-first-replenishment.

Weikmans, R., and J.T. Roberts. 2019. "The International Climate Finance Accounting Muddle: Is There Hope on the Horizon?" Climate and Development 11 (2): 97-111. https://doi.org/10.1080/17565529.2017.1410087.

Westphal, M.I., P. Canfin, A. Ballesteros, and J. Morgan. 2015. "Getting to \$100 Billion: Climate Finance Scenarios and Projections to 2020." Working Paper. Washington, DC: World Resources Institute. https://www.wri.org/research/ getting-100-billion-climate-finance-scenarios-and-projections-2020.

World Bank. 2015. 2014 Joint Report on Multilateral Development Banks' Climate Finance. Washington, DC: World Bank. https://www.worldbank.org/content/dam/ Worldbank/document/Climate/mdb-climate-finance-2014-joint-report-061615.pdf.

World Bank. 2021. World Development Indicators. (Database.) Washington, DC: World Bank. https://databank.worldbank.org/source/world-developmentindicators. Accessed August 6, 2021

WRI (World Resources Institute). 2018, "Green Climate Fund Contributions Calculator 1.0." https://www.wri.org/upload/gcf-calculator/index.html. 


\section{ACKNOWLEDGMENTS}

We are pleased to acknowledge our institutional strategic partners, who provide core funding to WRI: Netherlands Ministry of Foreign Affairs, Royal Danish Ministry of Foreign Affairs, and Swedish International Development Cooperation Agency. This work was also made possible through the support of the IKEA Foundation.

We thank the many people who contributed to discussions and provided helpful ideas as we developed this technical note as well as those who put time and thought into reviewing drafts and providing valuable feedback and suggestions.

We particularly acknowledge Giulia Christianson and Lorena Gonzalez for providing continuous guidance and strategic advice with this research.

We thank our colleagues at WRI who provided thoughtful review comments: Skylar Bee, Christina Chan, Giulia Christianson, Nathan Cogswell, Yamide Dagnet, Taryn Fransen, Lorena Gonzalez, and Gregory Taff.

We are grateful to the following external experts who provided valuable review comments and suggestions on earlier drafts of this guide: Tracy Carty, Raju Pandit Chhetri, Janine Felson, Jan Kowalzig, Federico Mazza, Rob Moore, Padraig Oliver, David Ryfisch, and Charlene Watson.

We also thank representatives of contributor countries and international financial institutions who provided feedback on the data, including: Jonathan Beynon, Gabriela Blatter, Sonja Djukic, Stephen Hammer, Amy Lewis, and Lyndsay Rae.

We benefited enormously from data and insights provided by Tracy Carty, Jan Kowalzig, and Bertram Zagema at Oxfam; Sarah Colenbrander at ODl; and Florian Egli and Anna Stünzi at ETH Zurich. We also thank Jane Ellis, Chiara Falduto, and Raphaël Jachnik at the OECD for having provided technical feedback.

Our thanks go to Gregory Taff and Emilia Suarez for shepherding the publication through the review process, and to William Berek for checking the data and calculations. We also wish to acknowledge those who provided valuable support in editing, graphic design, and layout, as well as communications and outreach for its release: Lauri Scherer, Jenna Park, Hayden Higgins, and Romain Warnault.

The contents of this publication are the sole responsibility of WRI and do not necessarily reflect the views and opinions of reviewers or funders. Any omissions, inaccuracies, or errors are our own.

\section{ABOUT THE AUTHORS}

Julie Bos is a research analyst within WRI's Sustainable Finance Center. She works on topics related to international climate finance, both in the public and private sectors.

Contact: julie.bos@wri.org

Joe Thwaites is an associate with WRI's Sustainable Finance Center. He works on enhancing the climate finance ambition of developed countries, supporting climatevulnerable countries in their engagement in international financial policymaking, and ensuring a just transition in the shift from fossil to clean financing.

Contact: joe.thwaites@wri.org
ABOUT WRI

World Resources Institute is a global research organization that turns big ideas into action at the nexus of environment, economic opportunity, and human well-being.

\section{Our Challenge}

Natural resources are at the foundation of economic opportunity and human well-being. But today, we are depleting Earth's resources at rates that are not sustainable, endangering economies and people's lives. People depend on clean water, fertile land, healthy forests, and a stable climate. Livable cities and clean energy are essential for a sustainable planet. We must address these urgent, global challenges this decade.

\section{Our Vision}

We envision an equitable and prosperous planet driven by the wise management of natural resources. We aspire to create a world where the actions of government, business, and communities combine to eliminate poverty and sustain the natural environment for all people.

\section{Our Approach}

COUNT IT

We start with data. We conduct independent research and draw on the latest technology to develop new insights and recommendations. Our rigorous analysis identifies risks, unveils opportunities, and informs smart strategies. We focus our efforts on influential and emerging economies where the future of sustainability will be determined.

\section{CHANGE IT}

We use our research to influence government policies, business strategies, and civil society action. We test projects with communities, companies, and government agencies to build a strong evidence base. Then, we work with partners to deliver change on the ground that alleviates poverty and strengthens society. We hold ourselves accountable to ensure our outcomes will be bold and enduring.

\section{SCALE IT}

We don't think small. Once tested, we work with partners to adopt and expand our efforts regionally and globally. We engage with decision-makers to carry out our ideas and elevate our impact. We measure success through government and business actions that improve people's lives and sustain a healthy environment.

Creative Copyright 2021 World Resources Institute. This work is licensed under the Creative Commons Attribution 4.0 International License

cc)commons (-) To view a copy of the license, visit http://creativecommons.org/licenses/by/4.0/ 